\title{
UNA VISIÓN PANORÁMICA AL CONVENIO OIT 169 Y SU IMPLEMENTACIÓN EN CHILE*
}

\section{Santiago Montt Oyarzún y Manuel Matta Aylwin}

El presente trabajo entrega una visión panorámica de los fundamentos y consecuencias legales de la adopción por parte de Chile del Convenio 169 de la Organización Internacional del Trabajo sobre Pueblos Indígenas y Tribales en Países Independientes. Dicho Convenio se estudia en el contexto de las relaciones entre el Derecho interno y el Derecho internacional, entendido este último como un sistema de "gobernanza global". Asimismo, se examina el Convenio a la luz de lo que ha sido la legislación indígena a lo largo de la historia de nuestro país. El análisis se centra en los derechos de participación, consulta y consentimiento previo, libre e informado de los artículos 6 y 7 y en los derechos sobre los recursos naturales contemplados en el artículo 15 del Convenio. De acuerdo a los

Santiago Montt. LLM y Doctor en Derecho, Yale University. MPP, Princeton University. Director del Centro de Regulación y Competencia, Facultad de Derecho, Universidad de Chile.

Manuel Matta. Abogado Universidad de Chile. LLM, University of California, Berkeley. Asociado del estudio Aylwin Abogados.

*Agradecemos la valiosa colaboración de nuestros ayudantes Jenny Silva Barría y Víctor Andrade Ramírez, ambos estudiantes de Derecho de la Universidad de Chile. Asimismo, agradecemos los comentarios de José Zalaquett, Lucas Sierra, Rodrigo Correa, José Aylwin, Luis Cordero, Matías Meza-Lopehandía y Ximena Insunza. 
autores, el Convenio 169 no debe ser motivo de especial preocupación. Por el contrario, su adopción por Chile constituye una excelente oportunidad para redefinir la política pública en materia de relación con los pueblos indígenas, mejorando sus condiciones de vida y disminuyendo la conflictividad del Estado y los privados con dichos pueblos.

Palabras clave: Convenio 169; pueblos indígenas; Derecho internacional; gobernanza global; derecho a la participación; derecho a los recursos naturales; relación Derecho interno-Derecho internacional.

Recibido: mayo 2010. Aceptado: agosto 2010.

\section{Introducción}

$\mathrm{D}$ esde nuestros orígenes coloniales la cuestión indígena ha ocupado un lugar central y casi permanente en la agenda pública. Se trata de un conflicto social y étnico cuyas profundas raíces históricas muestran que está aquí para quedarse y que, en realidad, contrariamente a las apariencias, nunca dejó de estar con nosotros ${ }^{1}$. Su solución (o encausamiento) es, por lo mismo, uno de los grandes desafíos generacionales que nos corresponde enfrentar si queremos vivir en una sociedad justa, inclusiva y pacífica.

Este trabajo analiza el alcance legal de la entrada en vigencia en nuestro país del Convenio 169 de la Organización Internacional del Trabajo sobre Pueblos Indígenas y Tribales en Países Independientes (1989) (en adelante, el Convenio 169) ${ }^{2}$. Las páginas que siguen presentan una visión panorámica de la implementación del Convenio 169, incluyendo su contexto, el Derecho internacional indígena. Esta visión

${ }^{1}$ Éste no sólo es el caso en Chile, sino en el mundo entero. Véanse Siegfried Wiessner, "Rights and Status of Indigenous Peoples: A Global Comparative and International Legal Analysis", 1999, p. 126; y Thomas M. Franck, Fairness in International Law and Institutions, 1995, pp. 140 y ss.

${ }^{2}$ El Convenio 169 entró en vigencia en nuestro país el 15 de septiembre de 2009 tras casi 18 años de tramitación en el Congreso (el tratado fue enviado al Congreso por el entonces Presidente Patricio Aylwin Azócar con fecha 21 de diciembre de 1990, Boletín 233-10). Fue ratificado el 15 de septiembre de 2008 y promulgado el 14 de octubre de 2008 (Decreto Supremo (RR. EE.) N 236 de 2 de octubre de 2008, publicado en el Diario Oficial de 14 de octubre de 2008). Entró en vigencia, conforme a su artículo 38.3, "doce meses después de la fecha en que haya sido registrada su ratificación". 
panorámica — necesaria para un tratado de la naturaleza y características del Convenio 169- se desarrolla, no obstante, concretizada en el análisis de dos de los conjuntos de derechos más complejos y conflictivos que contiene el Convenio 169: los derechos a participación, consulta y consentimiento previo, libre e informado - reconocido por los artículos 6 y 7 - y el derecho a los recursos naturales -reconocido por el artículo 15.

Nuestra perspectiva es "neutral" en el sentido específico que no somos activistas o expertos ni tampoco detractores de los temas indígenas. Los coautores somos dos abogados y académicos y, en definitiva, dos chilenos interesados en analizar el alcance y significado del Convenio 169 y sus implicancias para el desarrollo de una buena política pública indígena. Esta perspectiva neutral - que corre el obvio pero asumido riesgo de no dejar contento a nadie — nos pone a distancia de al menos dos posiciones antagónicas que suelen primar en el debate público actual: una que ve en el actual conflicto mapuche un mero escenario político montado por sectores de la izquierda nacional e internacional para apalancar sus posiciones ideológicas, y otra que está dispuesta a aceptar en bloque el Derecho internacional indígena, conforme a su interpretación más extrema, como un conjunto de derechos humanos no disponibles para los órganos democráticos de nuestra República.

Como punto de partida, consideramos que existe una importante deuda histórica con los pueblos indígenas en general, y con el pueblo mapuche en particular, surgida esta última a raíz de la mal llamada "Pacificación de la Araucanía", proceso que en realidad no fue otra cosa que un despojo institucionalmente organizado ${ }^{3}$. Ahora bien, más allá de la deuda histórica y la obligación moral de reparación ${ }^{4}$, tenemos

\footnotetext{
${ }^{3}$ Véase infra sección III.a.

${ }^{4}$ A modo de referencia, en Estados Unidos, el Senado federal acordó recientemente una resolución pidiendo disculpas formales a las tribus de ese país, por los años de políticas mal concebidas (ill-conceived policies) y por la violencia cometida por los ciudadanos norteamericanos en contra de los indígenas. Véase New York Times, 7 de octubre de 2009, http://www.nytimes.com/2009/10/08/us/politics/08brfs-ASYMBOLICAPO_BRF.html?_r=2 (última visita 29 de octubre de 2009). Véase Organización de Naciones Unidas, Declaración de las Naciones Unidas sobre los Derechos de los Pueblos Indígenas, Resolución aprobada por la Asamblea General, 13 de septiembre de 2007, disponible en http://www.un.org/esa/socdev/unpfii/es/drip.html (última visita 31 de octubre de 2009) (en adelante, Declaración ONU), particularmente el sexto considerando, donde se afirma lo siguiente: "Preocupada por el hecho de que los pueblos indígenas hayan sufrido injusticias históricas como resultado, entre otras cosas, de la colonización y enajenación de sus tierras, territorios y recursos, lo que les ha impedido ejercer, en particular, su derecho al desarrollo de conformidad con sus propias necesidades e intereses".
} 
la convicción que es nuestro deber como país desarrollar una sociedad multicultural e inclusiva.

Así lo exige, por lo demás, nuestra propia Constitución Política. $\mathrm{Su}$ artículo $1^{\circ}$ señala que el Estado chileno "debe contribuir a crear las condiciones sociales que permitan a todos y cada uno de los integrantes de la comunidad nacional su mayor realización espiritual y material posible", debiendo además promover la "integración armónica de todos los sectores de la Nación y asegurar el derecho de las personas a participar con igualdad de oportunidades en la vida nacional". Estos deberes primordiales son especialmente apremiantes cuando se trata de los sectores más desposeídos de nuestra población ${ }^{5}$.

El presente artículo está dirigido no sólo a abogados sino también a un público más amplio. Buscamos presentar una visión general del Derecho internacional indígena, su incorporación en el Derecho nacional y las consecuencias que de ello se derivan. Nuestro objetivo último es contribuir a desarrollar una cultura nacional de respeto por los derechos humanos de los pueblos indígenas, en especial a la luz de la historia de despojo, abuso y dominación de que han sido víctimas a lo largo de nuestra vida pre-republicana y republicana.

El artículo procede de la siguiente manera. La primera sección analiza el Derecho internacional indígena y los compromisos asumidos por Chile al ratificar el Convenio 169. Esta sección presenta el Convenio 169 en el contexto más general de la "gobernanza global" que caracteriza a una parte considerable del Derecho internacional moderno.

La segunda sección se hace cargo de las preguntas legales de rigor en materia de implementación de normas internacionales: ¿es el Convenio 169 un tratado? ¿Es un tratado de derechos humanos y, por ende, comprendido bajo el estatuto especial del artículo $5^{\circ}$ de nuestra Constitución? De ser ése el caso, ¿tiene un valor normativo superior a la ley? ¿Es autoejecutable o requiere ser reformulado como Derecho interno por nuestros órganos políticos?

${ }^{5}$ Véase Rodrigo A. Cerda, "Situación Socioeconómica Reciente de los Mapuches en la Región de la Araucanía”, 2009. Según explica y documenta Cerda, los mapuches de la IX Región viven en la región más pobre del país y son significativamente más pobres que los no mapuches de esa misma región; en definitiva, "hay una alta prevalencia de situaciones de pobreza y bajos ingresos" entre los mapuches de la IX Región, p. 98. El problema, de hecho, es universal, y explica la preocupación internacional por el tema. Véase Alexandra Xanthaki, Indigenous Rights and United Nations Standards. SelfDetermination, Culture and Land, 2007. 
La tercera sección presenta una sinopsis de lo que ha sido la legislación indígena a lo largo de nuestra historia pre-republicana y republicana, con un énfasis especial en la normativa y políticas actuales sobre la materia. Dado que el Convenio 169 impone la obligación de adecuar el ordenamiento legal, esta sección describe someramente la Ley Indígena vigente, sus principios, instituciones y los mecanismos que contempla para la protección de los derechos indígenas.

La sección cuarta estudia los derechos de participación, consulta y consentimiento previo, libre e informado establecidos en los artículos 6 y 7 del Convenio 169, y argumenta que es indispensable establecer mecanismos procesales que aseguren a los indígenas una participación efectiva. Enseguida, la sección quinta analiza los derechos sobre los recursos naturales establecidos en el artículo 15 del Convenio y afirma, entre otros aspectos generales, que resulta esencial definir los derechos indígenas con la mayor precisión posible y, al mismo tiempo, evitar esquemas de negociación bilateral de repartición de utilidades.

Las conclusiones llaman a tomar conciencia respecto a la importancia de implementar el Convenio 169 con seriedad y profundidad. Los derechos indígenas responden a la necesidad moral y legal de reparar el mal causado a lo largo de siglos de tratos inhumanos y vejatorios. La historia en Chile no tiene nada de excepcional comparada con la de otros países y, de hecho, parece ser un caso de laboratorio de los abusos y exclusiones sufridos por los pueblos indígenas. Los derechos indígenas han sido creados precisamente para casos como el nuestro y, en ausencia de una política pública interna robusta en su diseño y ejecución, nada justifica que nos creamos especiales y no implementemos apropiadamente las normas del Convenio 169.

\section{I. ¿A QUÉ (Y POR QUÉ) SE OBLIGÓ CHILE AL RATIFICAR EL CONVENIO 169? TRATADOS INTERNACIONALES Y DERECHO INTERNACIONAL COMO GOBERNANZA GLOBAL}

Esta sección presenta una breve descripción del Derecho internacional indígena y del Convenio 169. También analiza el contenido de este último en el contexto del Derecho internacional como gobernanza global. Finalmente, se intenta responder aquí a una pregunta que se oye frecuentemente entre nuestro medio: ¿por qué (o para qué) adhirió Chile al Convenio 169 ? 


\section{I.a. El Derecho internacional indígena y el Convenio 169}

El Convenio 169 fue aprobado por el pleno de la Conferencia General de la OIT en $1989^{6}$, y entró en vigencia en 1991 luego de transcurridos doce meses desde su ratificación por Noruega y México en $1990^{7}$. Hasta fines del 2010, 22 países lo han ratificado, incluyendo 14 naciones latinoamericanas ${ }^{8}$.

El Convenio 169, junto con la reciente Declaración de la ONU sobre los Derechos de los Pueblos Indígenas ${ }^{9}$, constituye uno de los cuerpos legales fundamentales del Derecho internacional indígena. Mediante la creación de derechos colectivos, el Convenio busca mejorar las condiciones de vida de los 5.000 pueblos indígenas y tribales que existen en el mundo y que representan una población de aproximadamente 370 millones de personas, repartidos por más de 70 países $^{10}$.

Desde un punto de vista de Derecho internacional, se trata de uno de los capítulos más recientes del Derecho internacional de los derechos humanos ${ }^{11}$. Como explica el profesor Reisman, los derechos indígenas se insertan dentro del sistema más amplio de protección de los derechos humanos:

${ }^{6}$ Es frecuente oír quejas respecto al rol de la OIT en temas indígenas. Más allá de consideraciones formales, la competencia de la OIT sobre asuntos indígenas es de larga data. Véanse Elina Meremiskaya, "El Convenio 169 de la OIT sobre Pueblos Indígenas y Tribales: Derecho Internacional y Experiencias Comparadas", 2010, y Observatorio Ciudadano, "Las Implicancias de la Ratificación del Convenio 169 de la OIT en Chile, 2009" ("I. El derecho internacional de los derechos humanos y los Pueblos Indígenas").

${ }^{7}$ Véase artículo 38.2 del Convenio 169.

${ }^{8}$ Los países que han ratificado son los siguientes: Noruega (1990), México (1990), Colombia (1991), Bolivia (1991), Costa Rica (1993), Paraguay (1993), Perú (1994), Honduras (1995), Dinamarca (1996), Guatemala (1996), Países Bajos (1998), Fiji (1998), Ecuador (1998), Argentina (2000), Venezuela (2002), Dominica (2002), Brasil (2002), Nepal (2007), España (2007), Chile (2008), Nicaragua (2010) y República Centroafricana (2010). Véase http://www.ilo.org/ilolex/spanish/newratframeS.htm (última visita 25 de enero de 2011).

${ }^{9}$ Las resoluciones de Naciones Unidas tienen el valor de recomendaciones, sin perjuicio de que la costumbre pueda ir otorgándoles un carácter vinculante. Asimismo, las declaraciones son una especie dentro del género "resolución".

${ }^{10}$ Organización Internacional del Trabajo, Los Derechos de los Pueblos Indigenas y Tribales en la Práctica: Una Guía sobre el Convenio Núm. 169 de la OIT, p. 9 (en adelante, OIT, Guía Larga).

${ }^{11}$ Véase S. James Anaya y Robert A. Williams, Jr., "The Protection of Indigenous Peoples' Rights over Lands and Natural Resources under the Inter-American Human Rights System", 2001, p. 33. 
El concepto "derechos indígenas" recientemente se ha llegado a entender, dentro del sistema más amplio de protección de los derechos humanos, como una nueva figura de reivindicaciones realizadas por los indígenas, para obtener la protección directa de la comunidad internacional y, en su caso, el reestablecimiento de los derechos de los que fueron privados en el pasado ${ }^{12}$.

Este estatus de derechos humanos que ostentan los derechos indígenas es consecuencia directa de la deuda histórica que las distintas naciones tienen con sus pueblos indígenas ${ }^{13}$. Como explica Wiessner, prácticamente todos los pueblos indígenas comparten un conjunto común de problemas que se derivan de la tortuosa relación que ha existido entre conquistadores y conquistados:

Primero, la tierra indígena libremente compartida, aunque no exclusivamente controlada, fue arrebatada. Segundo, la forma de vida del conquistador fue impuesta. Tercero, la autonomía política fue drásticamente restringida. Cuarto, los indígenas han sido frecuentemente relegados al estatus de la extrema pobreza, la enfermedad y la desesperanza ${ }^{14}$.

El Derecho internacional indígena en general y el Convenio 169 en particular han venido entonces a llenar una brecha que había quedado abierta en los textos tradicionales de derechos humanos en relación con los pueblos indígenas ${ }^{15}$. La brecha se ha llenado por la vía de crear derechos humanos de carácter colectivo, que se les reconoce a los indígenas en tanto pueblos y sólo mediatamente en cuanto individuos ${ }^{16}$. Tales derechos colectivos protegen especialmente la identidad cultural y las formas de vida, con especial preocupación por los componentes espaciales y políticos de dicha identidad y formas de vida ${ }^{17}$.

12 W. Michael Reisman, "Protecting Indigenous Rights in International Adjudication”, 1995, p. 350 (traducción de los autores).

${ }^{13}$ Véase Declaración ONU, n. 4, y Xanthaki, n. 5.

${ }^{14}$ Wiessner, n. 1, p. 98 (traducción de los autores).

${ }^{15}$ Véase James Anaya, Indigenous People in International Law, 1996, pp. 43 y ss.

16 Véase Xanthaki, n. 5, pp. 113 y ss. Véase también Observatorio Ciudadano, n. 6, "II. Los Contenidos del Convenio 169 de la OIT / 2. Naturaleza jurídica de los derechos".

${ }^{17}$ Algunos académicos critican la necesidad lógica de tener derechos humanos colectivos en favor de los pueblos indígenas, dado que el contenido de esos derechos podría deducirse de los derechos fundamentales tradicionales (vida, libertad, propiedad, etc.). Por el contrario, y sin llegar a plantear aquí una teoría de los derechos humanos de 
El Derecho internacional indígena comenzó a gestarse como manifestación de tres derechos humanos tradicionales: el derecho a la identidad cultural de los pueblos indígenas en tanto minorías étnicas ${ }^{18}$, el derecho a la propiedad privada ${ }^{19} \mathrm{y}$, en definitiva, el derecho de libre determinación de los pueblos (sin derecho a secesión) ${ }^{20}$. El punto de partida puede situarse en 1990, año en que el Comité de Derechos Humanos ${ }^{21}$ acogió por primera vez la reclamación de un pueblo indígena. En esa oportunidad, el organismo condenó a Canadá, declarando que el artículo 27 del Pacto Internacional de Derechos Civiles y Políticos incluía "el derecho de las personas, en comunidad con otras, a participar en aquellas actividades económicas y sociales que son parte de la cultura de la comunidad a la cual pertenecen" 22 . Casos posteriores del Comité, incluyendo una declaración general, han profundizado esta posición $^{23}$.

Por su parte, en el ámbito judicial, la Corte Interamericana de Derechos Humanos (CIDH) ha dado protección a los pueblos indígenas

segunda y tercera generación, nuestra visión es más bien política que lógica. En términos lógicos bastaría con proteger la dignidad humana, la igualdad y la libertad, pues todo lo demás podría deducirse de esos valores. Pero, desde un punto de vista político, una declaración tan escueta no basta. En efecto, nos vemos en la necesidad y urgencia de proteger una variedad más amplia y a la vez más específica de derechos humanos, pues ellos nos recuerdan los fracasos más serios de nuestro sistema político y social.

${ }^{18}$ Artículo 27 del Pacto Internacional de Derechos Civiles y Políticos, disponible en http://www2.ohchr.org/spanish/law/ccpr.htm (última visita 31 de octubre de 2009).

${ }^{19}$ Artículo 21 (Derecho a la Propiedad Privada) de la Convención Americana sobre Derechos Humanos (Pacto de San José).

${ }^{20}$ Artículo 1 del Pacto Internacional de Derechos Económicos, Sociales y Culturales, disponible en http://www2.ohchr.org/spanish/law/cescr.htm (última visita 31 de octubre de 2009) y artículo 1 del Pacto Internacional de Derechos Civiles y Políticos.

${ }^{21}$ El Comité de Derechos Humanos (que no debe ser confundido con la Comisión de Derechos Humanos de la ONU, cuyo continuador hoy es el Consejo de Derechos Humanos de la $\mathrm{ONU}$ ) es un organismo integrado por expertos independientes que supervisa el cumplimiento del Pacto Internacional de Derechos Civiles y Políticos. Véase http://www2.ohchr.org/spanish/bodies/hrc/index.htm (última visita 6 de noviembre de 2009).

22 Lubicon Lake Band v. Canada, Communication $N^{\circ}$ 167/1984 (26 March 1990), U.N. Doc. Supp. $N^{\circ} 40$ (A/45/40) at 1, 1990, para. 32.2., disponible en http:// www1.umn.edu/humanrts/undocs/session45/167-1984.htm (última visita, 23 de noviembre de 2009). Véase también Malcolm N. Shaw, International Law, 2003, p. 276.

${ }^{23}$ Véase ONU, Comité de Derechos Humanos, Comentario General $N^{\circ}$ 23: Los Derechos de las Minorias (Art. 27) 1994, disponible en http://www1.umn.edu/humanrts/ gencomm/hrcom23.htm (última visita, 23 de noviembre de 2009) (en adelante, Comité de Derechos Humanos, Comentario General $N^{\circ} 23$ ). Otros casos relevantes del Comité son Länsmann et al. vs. Finland (Comunicación No 511/1992), CCPR/C/52/D/511/1992, Lansman et al. vs. Finland (Communication N ${ }^{\circ}$ 671/1995), CCPR/C/58/D/671/1995. 
sobre la base de derechos humanos tradicionales. El fundamento legal ha sido el derecho a la propiedad privada garantizado por el artículo 21 del Pacto de San José. En el caso pionero en esta materia, Awas Tingni, un pueblo indígena, reclamaba en contra del gobierno de Nicaragua por haber otorgado una concesión para explotar bosques en territorio indígena. La Corte acogió la reclamación, ampliando el ámbito clásico del derecho de propiedad de manera de proteger la propiedad colectiva de los pueblos indígenas:

Entre los indígenas existe una tradición comunitaria sobre una forma comunal de la propiedad colectiva de la tierra, en el sentido de que la pertenencia de ésta no se centra en un individuo sino en el grupo y su comunidad. Los indígenas por el hecho de su propia existencia tienen derecho a vivir libremente en sus propios territorios; la estrecha relación que los indígenas mantienen con la tierra debe ser reconocida y comprendida como la base fundamental de sus culturas, su vida espiritual, su integridad y su supervivencia económica. Para las comunidades indígenas la relación con la tierra no es meramente una cuestión de posesión y producción sino un elemento material y espiritual del que deben gozar plenamente, inclusive para preservar su legado cultural y transmitirlo a las generaciones futuras ${ }^{24}$.

El reconocimiento expreso de los derechos indígenas en el ámbito internacional encuentra en el Convenio 169 un exponente destacado. Se trata del único tratado que reconoce derechos colectivos en favor de los pueblos indígenas y que se encuentra abierto para su ratificación. El principio de libre determinación es uno de sus pilares fundamentales y así lo afirma el preámbulo del tratado, al reconocer "las aspiraciones de esos pueblos a asumir el control de sus propias instituciones y formas de vida y de su desarrollo económico y a mantener y fortalecer sus identidades, lenguas y religiones, dentro del marco de los Estados en

${ }^{24}$ Corte Interamericana de Derechos Humanos, Caso de la Comunidad Mayagna (Sumo) Awas Tingni vs. Nicaragua, Sentencia de 31 de agosto de 2001 (Fondo, Reparaciones y Costas), 149, disponible en http://www.corteidh.or.cr/docs/casos/articulos/ Seriec_79_esp.pdf (última visita 29 de octubre de 2009). Véase también Caso de la Comunidad Indigena Yakye Axa vs. Paraguay, sentencia de 17 de junio de 2005 (Fondo, Reparaciones y Costas), 127-130 [en adelante, Caso Yakye Axa], Caso de la Comunidad Indigena Sawhoyamaxa vs. Paraguay, sentencia de 29 de marzo de 2006, 116-144 [en adelante Caso Sawhoyamaxa, y Caso del Pueblo Saramaka vs. Surinam, sentencia del 28 de noviembre de 2007 (Excepciones Preliminares, Fondo, Reparaciones y Costas), 89-186 [en adelante, Caso Saramaka]. 
que viven" 25 . Este principio - el que, insistimos, no incluye el derecho a secesión ${ }^{26}$ - se aprecia implícitamente también en el artículo 7.1 del tratado:

Los pueblos interesados deberán tener el derecho de decidir sus propias prioridades en lo que atañe al proceso de desarrollo, en la medida en que éste afecte a sus vidas, creencias, instituciones y bienestar espiritual y a las tierras que ocupan o utilizan de alguna manera, y de controlar, en la medida de lo posible, su propio desarrollo económico, social y cultural. Además, dichos pueblos deberán participar en la formulación, aplicación y evaluación de los planes y programas de desarrollo nacional y regional susceptibles de afectarles directamente.

La superación de la postergación, discriminación y vejación sufridas por los pueblos indígenas constituye uno de los objetivos medulares del Convenio 169. Así, los artículos 2 y 3 exigen a los Estados desarrollar acciones coordinadas y sistemáticas ${ }^{27}$, esto es, la adopción de una actitud proactiva dirigida a respetar los derechos de los pueblos indígenas, incluyendo la igualdad de derechos, la no-discriminación y la eliminación de diferencias socioeconómicas que existan entre los indígenas y los demás ciudadanos ${ }^{28}$. Del mismo modo, el artículo 7.2 exige priorizar el "mejoramiento de las condiciones de vida y de trabajo y del nivel de salud y educación de los pueblos interesados", y el artículo 12 , que se establezcan acciones y procedimientos legales que permitan asegurar la protección efectiva de los derechos de los indígenas.

En cuanto a los valores colectivos - que constituyen la nota característica del Derecho internacional indígena-, el Convenio 169 se preocupa particularmente de la integridad social, cultural y económica,

${ }^{25}$ Convenio 169, Preámbulo, 5.

${ }^{26}$ En términos estrictos, el Convenio 169 - particularmente su artículo 1.3 - no reconoce en forma expresa que los pueblos indígenas gozan del derecho a la libre determinación del artículo $1^{\circ}$ del Pacto Internacional de Derechos Civiles y Políticos y del Pacto Internacional de Derechos Económicos, Sociales y Culturales. Ahora bien, la Declaración de la ONU, que sí reconoce expresamente en sus artículos $3^{\circ}$ y $4^{\circ}$ el derecho a la libre determinación, niega en el artículo 46 que dicho derecho pueda entenderse "en el sentido de que autoriza o fomenta acción alguna encaminada a quebrantar o menoscabar, total o parcialmente, la integridad territorial o la unidad política de Estados soberanos e independientes".

${ }^{27}$ OIT, Guía Larga, n. 10, p. 29 y ss.

${ }^{28}$ Véase también el artículo 33 del Convenio 169. 
así como de la preservación de las formas de vida propias de las comunidades indígenas. Entre otros, cabe destacar aquí su artículo 5:

\begin{abstract}
Al aplicar las disposiciones del presente Convenio: a) deberán reconocerse y protegerse los valores y prácticas sociales, culturales, religiosos y espirituales propios de dichos pueblos y deberá tomarse debidamente en consideración la índole de los problemas que se les plantean tanto colectiva como individualmente; b) deberá respetarse la integridad de los valores, prácticas e instituciones de esos pueblos; c) deberán adoptarse, con la participación y cooperación de los pueblos interesados, medidas encaminadas a allanar las dificultades que experimenten dichos pueblos al afrontar nuevas condiciones de vida y de trabajo.
\end{abstract}

El derecho a la participación, consulta y consentimiento previo, libre e informado que el Convenio 169 reconoce a los pueblos indígenas en los artículos 6 y 7 se enmarca precisamente en el contexto de los valores colectivos. Estos derechos participativos constituyen los guardianes fundamentales de los derechos humanos indígenas materiales y aseguran además la incorporación al proceso político de minorías tradicionalmente postergadas y excluidas. Dada la importancia de estas normas para los efectos de este trabajo, nos permitimos citarlas en forma completa:

Artículo 6.1. Al aplicar las disposiciones del presente Convenio, los gobiernos deberán: a) consultar a los pueblos interesados, mediante procedimientos apropiados y en particular a través de sus instituciones representativas, cada vez que se prevean medidas legislativas o administrativas susceptibles de afectarles directamente; b) establecer los medios a través de los cuales los pueblos interesados puedan participar libremente, por lo menos en la misma medida que otros sectores de la población, y a todos los niveles en la adopción de decisiones en instituciones electivas y organismos administrativos y de otra índole responsables de políticas y programas que les conciernan; c) establecer los medios para el pleno desarrollo de las instituciones e iniciativas de esos pueblos, y en los casos apropiados proporcionar los recursos necesarios para este fin. 2. Las consultas llevadas a cabo en aplicación de este Convenio deberán efectuarse de buena fe y de una manera apropiada a las circunstancias, con la finalidad de llegar a un acuerdo o lograr el consentimiento acerca de las medidas propuestas.

Artículo 7.1. Los pueblos interesados deberán tener el derecho de decidir sus propias prioridades en lo que atañe al proce- 
so de desarrollo, en la medida en que éste afecte a sus vidas, creencias, instituciones y bienestar espiritual y a las tierras que ocupan o utilizan de alguna manera, y de controlar, en la medida de lo posible, su propio desarrollo económico, social y cultural. Además, dichos pueblos deberán participar en la formulación, aplicación y evaluación de los planes y programas de desarrollo nacional y regional susceptibles de afectarles directamente. 2. El mejoramiento de las condiciones de vida y de trabajo y del nivel de salud y educación de los pueblos interesados, con su participación y cooperación, deberá ser prioritario en los planes de desarrollo económico global de las regiones donde habitan. Los proyectos especiales de desarrollo para estas regiones deberán también elaborarse de modo que promuevan dicho mejoramiento. 3. Los gobiernos deberán velar por que, siempre que haya lugar, se efectúen estudios, en cooperación con los pueblos interesados, a fin de evaluar la incidencia social, espiritual y cultural y sobre el medio ambiente que las actividades de desarrollo previstas puedan tener sobre esos pueblos. Los resultados de estos estudios deberán ser considerados como criterios fundamentales para la ejecución de las actividades mencionadas. 4. Los gobiernos deberán tomar medidas, en cooperación con los pueblos interesados, para proteger y preservar el medio ambiente de los territorios que habitan.

Aparte de la participación, consulta y consentimiento previo, libre e informado, el Convenio regula también el "enlace" entre las culturas indígenas y la cultura dominante en cada país, exigiendo se tomen en serio las costumbres y derechos propios de los indígenas (artículos 8,9 y 10). Esto incluye el derecho de los pueblos indígenas a castigar a sus miembros conforme a sus tradiciones penales y a ser castigados conforme a los derechos penales nacionales siempre que se tengan en cuenta las particularidades económicas, sociales y culturales que les son propias y evitando las penas de cárcel.

Otra dimensión del Convenio que resulta esencial para la preservación de la integridad y las formas de vida indígena es la relación de los pueblos con la tierra. El artículo 13.1 exige a los gobiernos "respetar la importancia especial que para las culturas y valores espirituales de los pueblos interesados reviste su relación con las tierras o territorios", debiendo además, conforme al artículo 14, "reconocerse a los pueblos interesados el derecho de propiedad y de posesión sobre las tierras que tradicionalmente ocupan" y salvaguardarse su derecho a utilizar las tie- 
rras a las que "hayan tenido tradicionalmente acceso para sus actividades tradicionales y de subsistencia".

Enseguida, dentro del acápite "tierras", el artículo 15 define otro de los preceptos cuya implementación estudiaremos en detalle más adelante, esto es, el derecho sobre los recursos naturales propios (artículo 15.1) y los recursos naturales de propiedad del Estado (artículo 15.2):

1. Los derechos de los pueblos interesados a los recursos naturales existentes en sus tierras deberán protegerse especialmente. Estos derechos comprenden el derecho de esos pueblos a participar en la utilización, administración y conservación de dichos recursos. 2. En caso de que pertenezca al Estado la propiedad de los minerales o de los recursos del subsuelo, o tenga derechos sobre otros recursos existentes en las tierras, los gobiernos deberán establecer o mantener procedimientos con miras a consultar a los pueblos interesados, a fin de determinar si los intereses de esos pueblos serían perjudicados y en qué medida, antes de emprender o autorizar cualquier programa de prospección o explotación de los recursos existentes en sus tierras. Los pueblos interesados deberán participar siempre que sea posible en los beneficios que reporten tales actividades, y percibir una indemnización equitativa por cualquier daño que puedan sufrir como resultado de esas actividades ${ }^{29}$.

Otros derechos vinculados a la relación con la tierra son el derecho de los pueblos a no ser trasladados de las tierras que ocupan (artículo 16), el respeto a las modalidades de transmisión de la tierra conforme al Derecho indígena (artículo 17), el establecimiento de sanciones a las interferencias de terceros contra la propiedad indígena (artículo 18) y una denominada "equivalencia" de condiciones ante ciertos programas agrarios nacionales a fin de que puedan desarrollar sus tierras e incluso adquirir tierras adicionales en la medida en que sean necesarias para su subsistencia (artículo 19).

Por otra parte, el Convenio 169 también establece normas favorables a los indígenas en materia laboral (artículo 20), formación profesional, artesanía e industrias rurales (artículos 21 a 23), seguridad social y salud (artículos 24 y 25) y educación y medios de comunicación (artículos 26 a 31). Todos estos derechos, que escapan al ámbito de este

${ }^{29}$ Conforme al artículo 13.2, "La utilización del término 'tierras' en los artículos 15 y 16 deberá incluir el concepto de territorios, lo que cubre la totalidad del hábitat de las regiones que los pueblos interesados ocupan o utilizan de alguna otra manera”. 
trabajo, exigen en definitiva de parte de los gobiernos el diseño e implementación de políticas públicas inclusivas, pluralistas y multiculturales, destinadas a asegurar a los pueblos indígenas y sus miembros su más pleno desarrollo material y espiritual posible.

\section{I.b. El Convenio 169 y el Derecho internacional como gobernanza global $^{30}$}

Descrito el Convenio 169 en sus elementos esenciales, podemos explicar ahora cómo los aspectos más complejos del mismo no radican en su texto sino fuera de él. Esto se debe al profundo cambio que ha vivido el Derecho internacional post Guerra Fría. Una parte considerable del Derecho internacional tiene hoy en día una pretensión de "gobernanza global" que lo distingue del antiguo Derecho de tratados o consuetudinario del pasado.

Una de las características más notables de esta nueva era de Derecho global es la expansión de diversos mecanismos supranacionales de gobernanza ${ }^{31}$. El grado de interdependencia que exhibe nuestro mundo global demanda el establecimiento de tales mecanismos ${ }^{32}$. Ahora bien, estos sistemas de cooperación y coordinación exigen que los Estados deleguen soberanía en favor de las instituciones supranacionales que los conforman ${ }^{33}$.

Si bien los tratados internacionales siguen estableciendo los parámetros bajo los cuales los Estados se obligan en el plano internacional, es muy frecuente que los gobiernos otorguen su consentimiento a textos

${ }^{30}$ Para un desarrollo más extenso sobre la idea del Derecho internacional como gobernanza global, véase Santiago Montt, State Liability in Investment Treaty Arbitration. Global Constitutional and Administrative Law in the BIT Generation, 2009, pp. 125-161.

31 Véanse Laurence R. Helfer \& Graeme B. Dinwoodie, "Designing NonNational Systems: The Case of the Uniform Domain Name Dispute Resolution Policy", 2001, pp. 144-145; Daniel C. Esty, "Good Governance at the Supranational Scale: Globalizing Administrative Law", 2006, p. 1495; y David Held, "The Transformation of Political Community: Rethinking Democracy in the Context of Globalization", 1999, p. 84.

32 Véanse Eric Stein, "International Integration and Democracy: No Love at First Sight", 2001, pp. 498-490; Laurence R. Helfer, "Constitutional Analogies in the International Legal System”, 2003, pp. 194-195, y Esty, n. 31, p. 1493.

${ }^{33}$ Véase Thomas Cottier \& Maya Hertig, "The Prospects of $21^{\text {st }}$ Century Constitutionalism”, 2003, p. 302. Véanse también José E. Alvarez, International Organizations as Law Makers, 2005, pp. 401 y ss.; Thomas Franck (ed.), Delegating State Powers: The Effect of Treaty Regimes on Democracy and Sovereignty, 2000, y Esty, n. 31, p. 1518. 
que son abiertos o ambiguos, lo que genera una delegación de poderes implícita hacia los órganos de administración o de solución de controversias establecidos en dichos instrumentos. Como explica certeramente Kumm:

Los tratados, actualmente, aunque aún vinculantes únicamente para aquellos que los ratifican, cada vez delegan mayores poderes a órganos creados por dichos tratados con carácter cuasi-legislativos o cuasi-judiciales. Dentro de las materias circunscritas sobre las que tienen jurisdicción, estos órganos se encuentran autorizados bajo el tratado para desarrollar y determinar el contenido específico de las obligaciones a las cuales los Estados se encuentran sometidos. Esto significa que, aunque los Estados han consentido al tratado como un marco para el tratamiento de una específica variedad de materias, una vez que ellos han sido firmados, los derechos y obligaciones específicos son determinados sin su consentimiento por los órganos del tratado ${ }^{34}$.

Como consecuencia del poder y fuerza de este Derecho internacional post Guerra Fría, la antigua pretensión monopolística del Estado sobre el Derecho interno ha llegado a su $\mathrm{fin}^{35}$. La globalización, en cuanto proceso, "quita a los Estados individuales la capacidad de control del día a día de las actividades que ocurren en su territorio. Con la globalización, un país ya no es más "una isla en sí misma"”36. Piénsese, por ejemplo, por una parte, en los arbitrajes de inversiones conforme a tratados de protección de inversiones o en el mecanismo de solución de controversias de la OMC, o, por otra parte, en la solución de controversias criminales ante la Corte Penal Internacional.

En todos estos casos el diagnóstico es similar y trasciende a las sensibilidades políticas de izquierdas o derechas: la erosión de la soberanía y, como explican Cottier y Hertig, el hecho que nuestra Constitución nacional es ahora un cuerpo de naturaleza "parcial":

${ }^{34}$ Mattias Kumm, "The Legitimacy of International Law: A Constitutionalist Framework”, 2004, pp. 910-911 (traducción de los autores).

35 Véase Anne-Marie Slaughter, A New World Order, 2004, p. 262. Véase también Edward T. Hayes, "Changing Notion of Sovereignty and Federalism in the International Economic System: A Reassessment of WTO Regulation of Federal States and the Regional and Local Governments within their Territories", 2004, p. 8.

${ }^{36}$ Trevor C. Hartley, European Union Law in a Global Context, 2004, p. xv. Entre nosotros, véase Hernán Salinas Burgos, "Los Tratados Internacionales ante la Reforma Constitucional", 2007, p. 492. 
La constitución no puede por sí misma seguir pretendiendo contener un marco regulatorio que abarque al Estado en su totalidad. Conceptualmente, debido a la "externalización de funciones constitucionales", la Constitución hoy y en el futuro debe ser considerada una "constitución parcial", la que es completada por otros niveles de governanza ${ }^{37}$.

Ahora bien, ¿por qué es esto relevante para efectos del análisis del Convenio 169? Porque, como adelantamos, el Derecho internacional indígena comparte esta pretensión de gobernanza global propia del Derecho internacional moderno. En términos de Kumm, los Estados terminan sujetos a obligaciones en materia de protección indígena que van más allá de aquellas a las cuales prestaron su consentimiento.

Esta afirmación no es difícil de demostrar. La generalidad de los tratados de derechos humanos - incluyendo el artículo 21 del Pacto de San José y la mayoría de las normas del Convenio 169- se caracterizan por estar redactados en un lenguaje abierto, cuyo potencial expansivo permite la articulación de esquemas de gobernanza global ${ }^{38}$. Precisamente en un caso relativo a protección de tierras indígenas, la CIDH ha señalado que los "tratados de derechos humanos son instrumentos vivos cuya interpretación tiene que adecuarse a la evolución de los tiempos y, en particular, a las condiciones de vida actuales" 39 .

Este potencial expansivo puede verse en práctica tanto en los países que no han ratificado el Convenio 169 como en los que sí lo han hecho. En cuanto a los primeros, en el caso Saramaka, la CIDH interpretó el artículo 21 del Pacto de San José a la luz del Convenio 169, no

${ }^{37}$ Cottier \& Hertig, n. 33, pp. 303-304 (traducción de los autores).

${ }^{38}$ Como explica Stephen Gardbaum, "Human Rights and International Constitutionalism", 2009, p. 249, "el crecimiento del sistema de derechos humanos es una parte crítica para aquellos que argumentan que han ocurrido alteraciones fundamentales en el Derecho internacional que justifican un cambio general de paradigmas, desde una concepción de soberanía igualitaria a una más vertical o constitucionalista (...) la transformación de los sujetos básicos de Derecho internacional representa un cambio del modelo de Derecho privado del Derecho internacional, entendido exclusivamente como regulación de relaciones entre soberanías igualitarias, a un modelo de derecho público que comprende también regulación vertical de relaciones entre Estados e individuos: en otras palabras, un cambio desde funciones contractuales a funciones constitucionales" (traducción de los autores).

${ }^{39}$ Corte Interamericana de Derechos Humanos, Caso de la Comunidad Mayagna (Sumo) Awas Tingni vs. Nicaragua, n. 24, considerando 146. 
obstante que Surinam no lo había ratificado ${ }^{40}$. En cuanto a los segundos, el Convenio 169, dada su condición de tratado internacional, debe ser interpretado de conformidad con el Derecho internacional indígena y de los derechos humanos, incluyendo, según algunos, los textos aprobados con posterioridad al mismo. Esto por cuanto los tratados se interpretan conforme a "la regla general" establecida en el artículo 31 de la Convención de Viena ${ }^{41}$, particularmente la regla 3(c), que exige tomar en cuenta "toda forma pertinente de derecho internacional aplicable en las relaciones entre las partes".

Lo anterior nos lleva a uno de los aspectos más complejos de este Derecho con pretensiones de gobernanza global: la relación entre el Convenio 169 y la Declaración de la ONU de 2007 sobre Derechos de los Pueblos Indígenas, cuyo texto va claramente más allá que el del primero $^{42}$. Si bien algunos niegan que la Declaración pueda afectar el alcance del Convenio 169, la perspectiva más indigenista afirma sin rodeos que "[e]l Convenio núm. 169 y la Declaración de las Naciones Unidas son compatibles y se refuerzan mutuamente"43.

En términos estrictos, las declaraciones de la ONU no son una fuente formal de Derecho internacional (sin perjuicio de su consideración como Derecho internacional consuetudinario $)^{44}$. Pero, de todos modos, para quienes las suscriben, la fuerza de dichas declaraciones resulta difícil o imposible de esquivar. Y, ciertamente, Chile suscribió la Declaración ONU. Para todos los efectos prácticos, no cabe duda que dicha Declaración, así como toda norma que pueda dictarse o suscribirse a futuro, va a "jalar hacia arriba" el Convenio 169 en lo que respecta a su aplicación en los foros internacionales e, indirectamente, en los nacionales.

${ }^{40}$ Corte Interamericana de Derechos Humanos, Caso del Pueblo de Saramaka vs. Surinam, n. 24. Ver especialmente pp. 130-131.

${ }^{41}$ Convención de Viena sobre el Derecho de los tratados, suscrita en Viena, 23 de mayo de 1969, en vigencia desde 27 de enero de 1980, 1155 UNTS 331 (en adelante, Convención de Viena).

${ }^{42}$ Existe además un borrador de Declaración Americana sobre Derechos de los Pueblos Indigenas, disponible en http://www.cidh.org/Indigenas/ProyectoDeclaracion. htm (última visita, 6 de noviembre de 2009).

${ }^{43}$ OIT, Guía Larga, n. 10, p. 5.

${ }^{4}$ Véase James Anaya y Siegfried Wiessner, The UN Declaration on the Rights of Indigenous Peoples: Towards Re-empowerment, 2007. 
I.c. ¿Por qué Chile ratificó el Convenio 169? ¿Por qué no seguimos el ejemplo de Estados Unidos, Canadá, Australia y Nueva Zelandia, que no lo hicieron?

Por qué los países adhieren a los distintos mecanismos de gobernanza internacional es una pregunta obligada para quienes estudian estos sistemas. Desde un punto de vista político, lo usual es que "izquierdas" reclamen contra regímenes de "derecha" y que "derechas" lo hagan contra regímenes de "izquierda". Lo notable es que ambos bandos utilizan argumentos similares tales como la soberanía nacional, la falta de legitimidad del Derecho internacional, el principio de subsidiariedad y la autodeterminación democrática, entre otros ${ }^{45}$.

¿Por qué Chile terminó por ratificar el Convenio 169 luego de transcurridos casi 20 años desde la celebración del mismo? Esta pregunta, que se repite frecuentemente entre nosotros, toma más realce ante el hecho de que a lo menos cuatro países que tienen importantes poblaciones indígenas -Estados Unidos, Canadá, Australia y Nueva Zelandia - no han suscrito ni el Convenio 169 ni la Declaración de la ONU (aunque Australia sí terminó por dar su apoyo a la Declaración el 3 de abril de $2009^{46}$ ).

Los mecanismos o sistemas de gobernanza global son de muy distinto tipo y operan sobre realidades muy variadas, lo que hace muy difícil plantear afirmaciones o teorías que sean válidas en todos los contextos ${ }^{47}$. Hay algunos que mantienen una visión optimista que justifica estos mecanismos en la idea de un check-and-balance adicional a los ya existentes a nivel doméstico ${ }^{48}$. Así, los mecanismos de gobernanza internacional permitirían romper el status quo defendido por los grupos de interés que tienen capturado el proceso político doméstico ${ }^{49}$.

\footnotetext{
${ }^{45}$ Véase Stein, n. 32, p. 489.

${ }^{46}$ Véase http://www.hreoc.gov.au/about/media/media_releases/2009/21_09.html (última visita, 7 de noviembre de 2009).

${ }^{47}$ Véase Neil Walker, "Beyond Boundary Disputes and Basic Grids: Mapping the Global Disorder of Normative Orders", 2008, p. 379.

${ }^{48}$ Véase Kumm, n. 34, p. 919. Véase también, Gardbaum, n. 38, p. 254.

${ }^{49}$ Por ejemplo, para el caso europeo, véase Karl-Heinz Ladeur, "Globalization and the Conversion of Democracy to Polycentric Networks: Can Democracy Survive the End of the Nation State?", 2004, pp. 117-118. Para el caso de la OMC, véase John O. McGinnis y Mark L. Movsesian, “The World Trade Constitution”, 2000.
} 
Esta visión optimista permite explicar por qué los países llamados overcompliants, como Estados Unidos, Canadá, Australia y Nueva Zelandia, no aprobaron el Convenio 169, y países como Chile, sí. Son precisamente los que tienen un sistema doméstico más desarrollado y favorable para los indígenas quienes menos necesidad tienen de un check-and-balance adicional. Cuando el sistema político interno ha sido sensible y receptivo a las necesidades y requerimientos de las minorías indígenas, tales minorías no tienen la necesidad de apalancarse desde el sistema internacional para desestructurar los equilibrios internos.

Por el contrario, países como Chile, que cuentan con una política pública indígena doméstica más bien precaria y errática, son precisamente los destinos naturales de este mecanismo de gobernanza global que busca cambiar el estado de cosas interno ${ }^{50}$. Por eso, la pregunta de por qué Chile aprobó el Convenio 169 se responde, a nuestro juicio, precisamente apelando a la incapacidad que hemos tenido de idear y mantener una política indígena consistente a través del tiempo y que responda a las necesidades y características de nuestros pueblos originarios.

Ahora bien, el no ser capaces de hacer las cosas en forma autónoma tiene asociado un costo. En los sistemas de gobernanza global aquellas personas que Martin Shapiro llama "expertos y entusiastas" 51 tienen un peso específico muy alto. $\mathrm{Y}$, tal como explica este mismo autor, "Mientras el vehículo a la participación en los asuntos públicos está dado por el conocimiento y/o la pasión, tanto el conocimiento como la pasión generan perspectivas que no son aquellas que tenemos el resto de nosotros. Muy pocos de nosotros realmente disfrutaría vivir en una casa diseñada por Frank Lloyd Wright" ${ }^{\prime 52}$.

Tratándose del Derecho internacional indígena, los pueblos indígenas y los expertos y entusiastas ${ }^{53}$ han estado sobrerrepresentados en la formulación de las políticas públicas globales. Tanto así que, según

${ }^{50}$ Organización Internacional del Trabajo, Guía para la Aplicación del Convenio Núm. 169 de la OIT, disponible en http://www.oit.or.cr/mdtsanjo/indig/conten.htm (última visita 28 de octubre de 2009) ("[E]ste convenio ha tenido una influencia significativa en la definición de políticas y programas nacionales”) (en adelante, OIT, Guía Corta).

${ }^{51}$ Martin Shapiro, “Administrative Law Unbounded: Reflections on Government and Governance", 2001, p. 376.

${ }^{52}$ Ibíd., p. 374 (traducción de los autores).

53 Véase Benedict Kingsbury, “'Indigenous Peoples' in International Law: A Constructivist Approach to the Asian Controversy", 1998, p. 414. 
algunos, el desarrollo de varios de los productos normativos de este sistema - particularmente la Declaración ONU— ni siquiera ha estado bajo el control de los Estados, con la consiguiente falta de legitimidad democrática ${ }^{54}$.

En todo caso y para cerrar este punto, no podemos pasar por alto que vivimos en un mundo globalizado y que muchas políticas públicas se desarrollan hoy en día a través de mecanismos de gobernanza global ${ }^{55}$. No es inusual que un país pequeño como Chile no pueda mantenerse al margen de estos sistemas de gobernanza internacional ${ }^{56}$. Si a ello sumamos que internamente nuestra política indígena ha sido deficiente, no podemos objetar seriamente la decisión de nuestro gobierno de ratificar el Convenio 169. Bienvenidos al mundo contemporáneo del Derecho internacional como gobernanza global.

\section{JERARQUÍA NORMATIVA Y EJECUTABILIDAD DEL CONVENIO 169 ANTE EL DERECHO CHILENO}

La jerarquía normativa del Derecho internacional en el orden interno no es un punto de Derecho internacional sino de Derecho interno ${ }^{57}$. Por ello, para determinar el estatus del Convenio 169 es necesario partir por aclarar si Chile es, en principio, un país "monista" o "dualis-

${ }^{54}$ Véase Robert McCorquodale, "The Individual and the International Legal System”, 2003, p. 317, quien comentando acerca de la Declaración de la ONU, afirma que "su importancia radica en el hecho de que el proceso de creación y desarrollo de este borrador [a la época del artículo aún era un proyecto] ha estado mayormente fuera del solo control de los Estados" (traducción de los autores).

${ }^{55}$ Véase Benedict Kingsbury, Nico Krisch y Richard B. Stewart, "The Emergence of Administrative Law", 2005, p.15.

${ }^{56}$ Como explica Walker, n. 47, p. 380 , "los Estados consideran en forma cada vez más recurrente que su sujeción [en áreas tales como derechos humanos transnacionales, entre otras], y la de otros Estados, a ciertos sistemas de normas fundamentales, así como también la capacidad de sus propios ciudadanos de confiar en dichas normas, forma parte integrante de su autodeclarada condición de miembros (en su carácter de Estados) de la 'comunidad internacional' y, por tanto, se trataría de una sujeción que es independiente del consentimiento específico a la norma respectiva” (traducción de los autores).

${ }^{57}$ Quienes creen encontrar respuesta a esta cuestión en el Derecho internacional, como por ejemplo en la Convención de Viena, están metodológica y políticamente equivocados. En cuanto manifestación clásica del Derecho internacional, la Convención de Viena rige las relaciones internacionales entre los Estados, no la aplicación del Derecho internacional en el plano interno. El Derecho internacional no exige a los países ser monistas, sino que reconoce que dicha decisión es soberana de cada Estado. 
ta". Luego se debe analizar si el Convenio 169 es o no una norma relativa a derechos humanos. Aclarados los dos puntos anteriores se puede entonces dar respuesta a la pregunta sobre la jerarquía normativa y ejecutabilidad del citado Convenio en el ordenamiento chileno.

\section{II.a. Dualismo vs. monismo ${ }^{58}$}

Desde una perspectiva comparada, la aplicación del Derecho internacional en el Derecho interno se explica por las tradicionales teorías dualistas o monistas ${ }^{59}$. Las teorías dualistas defienden la idea de dos órdenes diferentes: uno, el del Derecho internacional, que trata la relación entre los Estados, y otro, el del Derecho interno, que trata las relaciones entre privados y entre privados y el Estado. Ambos Derechos constituyen dos planos que no se tocan, y que carecen, respectivamente, del poder de alterar o modificar las reglas del otro ${ }^{60}$. La aplicación del Derecho internacional en el Derecho interno, cuando procede, es simplemente el resultado de un llamado de este último en tal sentido, tal como ocurre con el Derecho extranjero.

Por el contrario, las teorías monistas postulan la unidad del Derecho internacional y nacional. En el límite, los monistas radicales, como Kelsen, afirman que la norma primaria de la pirámide normativa está en el Derecho internacional y que desde ella recibe su valor y validez el Derecho interno. Como consecuencia, las normas de Derecho internacional tienen un estatus superior al Derecho interno y en caso de conflicto, prevalecen.

La discusión entre estas antiguas escuelas tiene un contenido político que corresponde a las ideologías prevalecientes durante los siglos XIX y XX. En el caso de las teorías dualistas, sus proponentes tra-

${ }^{58}$ Esta sección y la siguiente están basadas, aunque con actualizaciones importantes, en un trabajo previo de uno de nosotros. Véase Santiago Montt Oyarzún, “Aplicación de los Tratados Bilaterales de Protección de Inversiones por Tribunales Chilenos. Responsabilidad del Estado y Expropiaciones Regulatorias en un Mundo Crecientemente Globalizado", 2005.

${ }^{59}$ De acuerdo a Armin von Bogdandy, "Pluralism, Direct Effect, and the Ultimate Say: On the Relationship between International and Domestic Constitutional Law", 2008, p. 397, "La relación entre normas de derecho internacional y de derecho interno es aún entendida bajo conceptos desarrollados cien años atrás: monismo y dualismo" (traducción de los autores).

${ }^{60}$ Véase Montt Oyarzún, n. 58, p. 32. 
taban de defender y consolidar la soberanía de los nuevos Estados por sobre el idealismo internacionalista que normalmente acogían, al menos implícitamente, las visiones de los países europeos. Así, los Estados latinoamericanos fueron dualistas en el siglo XIX a objeto de defenderse de los "estándares mínimos internacionales" y de la protección diplomática (la llamada gunboat diplomacy). Después, durante el siglo xx, fueron dualistas los Estados marxistas, pues de esta forma evitaban recibir la influencia liberal por la vía del Derecho internacional ${ }^{61}$.

En la actualidad nadie postula un dualismo o monismo radical. Los tribunales domésticos aplican frecuentemente el Derecho internacional — especialmente en Estados Unidos y en Europa- y, por lo mismo, no puede razonablemente negarse la concurrencia efectiva de ambos sistemas normativos. No es sorpresa que, crecientemente, los publicistas eviten entrar en la discusión teórica entre monismo y dualismo ${ }^{62}$. Nadie pretende plantear teorías omnicomprensivas de carácter abstracto y dogmático.

Con todo, como dice Von Bogdandy, "el monismo es, básicamente, una noción moribunda que debe ser eliminada" ${ }^{3}$. Por el contrario, aunque el dualismo es también en sus extremos una doctrina insatisfactoria, al menos determina la manera valorativa correcta de abordar el problema: si bien no existe una separación estricta entre los distintos órdenes, los Estados sí deben poder inaplicar el Derecho internacional en el orden interno. Dicha doctrina explica además mejor la realidad comparada, pues casi todos los Estados inaplican el Derecho internacional cuando así lo determinan necesario ${ }^{64}$.

Ahora bien, la pretensión de gobernanza global del Derecho internacional moderno más la facultad de los Estados de inaplicar dicho Derecho nos lleva a compartir el esquema conceptual y valorativo propuesto por Von Bogdandy. Según este último, la relación entre los Derechos internacional e interno debe analizarse de acuerdo con la idea de "acoplamiento" (coupling). Dicho acoplamiento puede ser más "apreta-

${ }^{61}$ Véase Karl Joseph Partsch, "International Law and Municipal Law", 19922003, p. 1187.

${ }^{62}$ Véase Ian Brownlie, Principles of Public International Law, 2003, p. 33.

${ }^{63}$ Von Bogdandy, n. 59, p. 397.

${ }^{64}$ Esta facultad refleja ciertamente una actitud de confianza relativa (o desconfianza relativa) hacia el Derecho internacional, especialmente en áreas o materias donde existen negociaciones bilaterales o multilaterales permanentes, como en el comercio internacional. 
do" o más "suelto" 65 , lo que depende de la "mediación" que hagan de las normas internacionales tanto los órganos domésticos políticos como los judiciales y administrativos ${ }^{66}$.

La "mediación" a que se refiere Von Bogdandy es particularmente sensible a dos doctrinas: efecto directo (o, en jerga norteamericana, autoejecutabilidad) e interpretación conforme al Derecho internacional ${ }^{67}$. Entre ambas, la primera es la más importante para determinar el nivel de acoplamiento existente: mientras más intenso sea el reconocimiento del efecto directo de una norma internacional, mayor será el acoplamiento y, más importante aún, mayor será el efecto constitucionalizante que tendrá el Derecho internacional sobre el Derecho interno.

Ahora bien, según Von Bogdandy, en el mundo actual el acoplamiento no debe ser automático ni de iure como postulaban los monistas. Esto, porque no queremos reconocerle siempre y en toda ocasión efectos constitucionalizantes al Derecho internacional. Son los propios Estados los que deben controlar y determinar dichos efectos, y ello debe depender de la legitimidad de las normas internacionales de que se trate y de la posición que quiera darse al orden interno en el plano global:

Consideraciones de legitimidad dan sustento a la posición de que el efecto directo y la interpretación conforme son materias que deben ser decididas en base al Derecho constitucional interno. El posicionamiento del orden legal interno dentro de un mundo más amplio necesariamente afecta a materias fundamentales como son la democracia, la libre determinación y el propio entendimiento de la ciudadanía. Por esta razón, el posicionamiento debe ocurrir sobre la base de aquellas normas que gozan de la más alta legitimidad para ese grupo, esto es - a lo menos en la mayor parte de las democracias liberales-, las normas establecidas por la Constitución interna. Ésta es, al menos respecto de las democracias liberales, la solución más consistente con el constitucionalismo como teoría normativa ${ }^{68}$.

En definitiva, la posición de Von Bogdandy nos recuerda que no debemos adoptar una posición naïve respecto al Derecho internacional. El efecto directo y el correspondiente efecto constitucionalizante sólo

\footnotetext{
${ }^{65}$ Von Bogdandy, n. 59, p. 400.

${ }^{66}$ Ibíd. p. 401.

${ }^{67}$ Ibíd. p. 402.

${ }^{68}$ Ibíd. p. 403 (traducción de los autores).
} 
deben otorgarse a las normas que merezcan dichas prerrogativas, pero no a las demás. Corresponde entonces ahora analizar la relación entre Derecho internacional y nacional teniendo en cuenta la relevancia e impacto jurídico-político de los conceptos de acoplamiento, mediación y efecto directo o autoaplicabilidad.

\section{II.b. El Derecho internacional ante el Derecho chileno}

En contraste con la situación de otros países, el silencio de nuestra Constitución respecto al valor y jerarquía del Derecho internacional es llamativo. El resultado de este vacío es que toda la construcción teórica de la recepción del Derecho internacional es obra doctrinaria y jurisprudencial.

En términos generales, nuestros autores aceptan la incorporación del Derecho internacional en el Derecho interno. Primero, en relación al Derecho internacional consuetudinario, los publicistas han reconocido tradicionalmente su recepción en el Derecho nacional ${ }^{69}$. Como afirma Santiago Benadava, "en Chile el Gobierno, los tribunales y los autores han reconocido que el derecho internacional general forma parte del derecho chileno"70. Sin embargo, se afirma también que esta recepción cuenta con una gran limitación: "en el caso de conflicto inevitable entre la norma de derecho internacional consuetudinario y una ley interna, la ley interna prevalece (en el plano interno) sobre la norma de derecho internacional. En este caso, el juez debe aplicar la ley interna aun si la juzga contraria al derecho internacional general o consuetudinario"71.

Segundo, en lo que respecta a los tratados internacionales, la situación es más complicada. Partiendo por los aspectos formales, tal como lo ha señalado desde hace tiempo la Corte Suprema, la validez interna de los tratados requiere de la promulgación de los mismos mediante decreto supremo del Presidente de la República y su posterior

${ }^{69}$ De acuerdo con Francisco Orrego Vicuña y Francisco Orrego Bauzá, "National Treaty Law and Practice: Chile", 1999, p. 46. Véanse también, Eugenio Alberto Gaete González, "Derecho Internacional y Derecho de los Estados. Incorporación de los Derechos Humanos", 1996, p. 265; Santiago Benadava, "Las Relaciones entre Derecho Internacional y Derecho Interno ante los Tribunales Chilenos", 1992, pp. 10-26, y Santiago Benadava, Derecho Internacional Público, 1989, p. 73.

${ }^{70}$ Benadava, n. 69 (Derecho internacional...), p. 71.

${ }^{71}$ Ibíd. p. 73. 
publicación en el Diario Oficial ${ }^{72}$. La misma opinión manifiesta Santiago Benadava al decir que "los tratados destinados a ser aplicados en el plano interno requieren de un acto formal de recepción o incorporación. El tratado no es 'conocido' por los jueces nacionales a menos que haya sido puesto en su conocimiento en la forma prescrita por el derecho interno" $" 73$.

Esta postura frente a los tratados proviene originalmente de su asimilación normativa a la ley y de la aplicación por analogía de las normas de promulgación y publicación establecidas en la Constitución y el Código Civil ${ }^{74}$. En todo caso, como previene el Tribunal Constitucional en su sentencia de 24 de junio de 1999, la eventual distinta naturaleza normativa de los tratados y las leyes internas ${ }^{75}$, e incluso más, la distinta entrada en vigencia de los tratados en el plano internacional y en el Derecho interno, no constituyen obstáculos para que éstos deban ser promulgados y publicados a fin de que se incorporen al Derecho interno:

La promulgación y publicación de los tratados no está descrita en texto expreso de la Constitución, sino que obedece a una práctica impuesta por la doctrina, la costumbre y la jurisprudencia, a diferencia de lo que ocurre con la ley según lo prevé expresamente el artículo 72 de la Carta Fundamental ${ }^{76}$.

Más allá de los aspectos formales, y tal como bien advirtiera Benadava en la primera edición de su Manual en 1977, en Chile, por

${ }^{72}$ Gaceta de los Tribunales, 1921, primer semestre, p. 22. Véase también Orrego y Orrego, n. 69, p. 44. Dado su trasfondo político, es interesante señalar cómo en el caso del Pacto de Derechos Civiles y Políticos de 1966, ratificado por Chile en 1976 y vigente internacionalmente desde el 23 de marzo de 1976, la Corte Suprema afirmó sistemáticamente durante la década de los 1980 que por no estar promulgado ni publicado, no formaba parte del ordenamiento. Véase María Teresa Infante Caffi, "Los Tratados en el Derecho Interno Chileno: El Efecto de la Reforma Constitucional de 1989 Visto por la Jurisprudencia", 1996, p. 281.

73 Benadava, n. 69 (Derecho Internacional...), p. 71.

${ }^{74}$ Véase Orrego y Orrego, n. 69, p. 45.

${ }^{75}$ En la Sentencia de fecha 24 de junio de 1999, Rol 288, Requerimiento en contra del Acuerdo entre la República de Chile y la República de Argentina para precisar el recorrido del limite desde el Monte Fitz Roy hasta el Cerro Daudet, el Tribunal afirmó, en el considerando $6^{\circ}$, "que, cabe puntualizar, en primer término, que el tratado y la ley son fuentes de derecho diferentes".

${ }^{76}$ Considerando $7^{\circ}$ del la sentencia citada en la nota anterior. Véanse también considerandos $8^{\circ}$ a $11^{\circ}$. Actualmente, el artículo $54 \mathrm{~N}^{\circ} 1$ inciso $1^{\circ}$ de la Constitución, post reforma del 2005, señala que la aprobación de un tratado "se someterá, en lo pertinente, a los trámites de una ley", y el inciso $9^{\circ}$ exige que se le dé "debida publicidad" a hechos que digan relación, entre otros casos, con su entrada en vigor. 
regla general, la incorporación efectiva de los tratados depende de un requisito adicional: el tratado debe ser self-executing o autoaplicable - o de efecto directo-, lo que se cumpliría cuando sus "disposiciones son completas y detalladas" 77 . Por el contrario, si el tratado es non-selfexecuting es necesario que "se dicten normas legislativas para su aplicación interna" 78 .

Esta clasificación de los tratados en self-executing o autoejecutables y non-self-executing o no autoejecutables proviene del Derecho norteamericano ${ }^{79}$. De hecho, fue desde los Estados Unidos desde donde se propagó hacia los demás países del mundo, incluyendo Europa y Latinoamérica ${ }^{80}$. En Chile, esta clasificación ha sido tomada por la jurisprudencia hace relativamente poco tiempo. En efecto, la Corte Suprema parece haber empezado a utilizar el concepto de autoejecutabilidad, al menos implícitamente, antes que el Tribunal Constitucional. Las primeras referencias a la no autoejecutabilidad parecen encontrarse en fallos de la década de los ochenta ${ }^{81}$.

77 Santiago Benadava, Manual de Derecho Internacional Público, 1976, p. 89. Véase también Benadava, n. 69 (Derecho Internacional...), p. 72.

${ }^{78}$ Benadava, n. 69 (Derecho Internacional...), p. 72, agrega que "por ejemplo, un tratado en que las partes se obligan a prevenir y a castigar ciertos delitos contra los agentes diplomáticos y otras personas internacionalmente protegidas, requerirá además de una ley en que se definan estos delitos, se establezcan las penas, se extienda la jurisdicción de los tribunales nacionales, etc.”, pp. 72-73.

79 Véase Yuji Iwasawa, "The Doctrine of Self-Executing Treaties in the United States: A Critical Analysis", 1986, pp. 635 y ss. En el mismo sentido, Albert Bleckman, "Self-Executing Treaty Provisions", 1992-2003, p. 374. Esta doctrina aparece por primera vez en un famoso pasaje del juez en el caso Foster v. Neilson, 27 U.S. 253, p. 314 : "Nuestra Constitución declara los tratados como ley del país (Law of the Land). En consecuencia deben ser considerados por las cortes como equivalentes a un acto de la Legislatura, siempre que operen por sí mismos, sin la ayuda de ninguna norma legislativa. Pero cuando los términos de la estipulación importan un contrato — cuando cualquiera de las partes se encuentra obligada a realizar un determinado acto-, el tratado se dirige a los órganos políticos, no a los judiciales; y la Legislatura debe ejecutar el contrato antes de que llegue a ser una regla para las cortes" (traducción de los autores).

${ }^{80}$ Véase Iwasawa, n. 79, p. 628.

${ }^{81}$ En al menos tres casos la Corte Suprema ha rechazado la aplicación de un tratado por no considerarlo parte del ordenamiento jurídico al no estar implementado en el orden interno: a) caso Leopoldo Ortega Rodríguez, Fallos del Mes N ${ }^{\circ} 311$, octubre 1984, pp. 588 y ss., respecto al Pacto Internacional de Derechos Civiles y Políticos; b) caso Benedicto Enrique Figueroa Puentes, Fallos del Mes ํㅜ 310, septiembre de 1984, pp. 463 y ss., respecto al mismo tratado de la letra anterior; y, c) Recurso de inaplicabilidad presentado por Alfredo Insunza Bascuñán, de fecha 24 de agosto de 1990, citado en Revista Chilena de Derecho, $\mathrm{N}^{\circ} 23,1996$, p. 453, respecto a la Convención para la Prevención y Sanción del Delito de Genocidio. 
La exigencia de la autoejecutabilidad como requisito de incorporación parece haberse instalado en Chile en forma definitiva luego de su adopción por la jurisprudencia del Tribunal Constitucional a partir del año 2000. En efecto, la primera referencia explícita a esta clasificación aparece en la Sentencia Rol 309, de fecha 4 de agosto de 2000, que resolvió el requerimiento presentado en contra del Convenio $169^{82}$. En el considerando $48^{\circ}$ de esta sentencia, el Tribunal estableció las siguientes afirmaciones:

Los tratados, para su aplicación en el orden interno de un país, pueden contener dos tipos de cláusulas, denominadas por la doctrina "self executing" y "non self executing".

Las primeras son las que tienen el contenido y precisión necesarios que las habilita para ser aplicadas sin otro trámite como fuente del derecho interno. En otros términos, son autosuficientes, y entran a la legislación nacional cuando el tratado que las contiene se incorpora al derecho vigente. Las segundas son aquellas que requieren para su entrada en vigencia de la dictación de leyes, reglamentos o decretos que las implementen y, en tal evento, las hagan aplicables como fuente del derecho interno. En otras palabras, imponen la obligación al Estado, para que en uso de sus potestades públicas, sancione la normativa necesaria para que por esa vía les dé vigencia efectiva.

Pueden existir tratados que sólo contengan cláusulas auto ejecutables y otros que sólo contengan no ejecutables, como puede un mismo tratado contener unas y otras.

Esta precisión resulta determinante para pronunciarse sobre la inconstitucionalidad de los preceptos del tratado, toda vez que aquellos cuyas normas o algunas de ellas requieran, para tener fuerza interna, de una actividad legislativa o administrativa posterior, no pueden, por esa razón, entrar en contradicción desde pronto con el ordenamiento constitucional ya que no son normas vigentes ni tampoco lo serán cuando el Presidente de la República ratifique el tratado si es que es aprobado por el Congreso y el Ejecutivo decide así hacerlo. Si los preceptos que se deben dictar para implementarlo, llegaren a contener disposiciones contrarias a la Constitución, ello será decidido en su oportunidad por los órganos de control de constitucionalidad que la propia Carta Fundamental establece.

${ }^{82}$ Sentencia de fecha 4 de agosto de 2000, Rol 309, Requerimiento respecto del Convenio $N^{\circ} 169$, Sobre Pueblos Indígenas y Tribales en Países Independientes, Adoptado por la Organización Internacional del Trabajo, el 27 de Junio de 1989 [en adelante, Sentencia Rol 309]. 
Siendo así, en cada caso particular deberá previamente decidirse por este Tribunal si las disposiciones del tratado son o no auto ejecutables y, por ende, si quedarán incorporadas, sin necesidad de otro acto de autoridad, al derecho interno. Sólo en el evento de que la norma sea autoejecutable, el Tribunal debe —en esta instancia jurisdiccional- pronunciarse sobre su constitucionalidad.

De acuerdo a la posición del Tribunal, la calidad de non-selfexecuting o no-autoejecutable impide no sólo que un juez chileno aplique directamente una norma del tratado en un conflicto interno, sino además que la referida norma de Derecho internacional sea incorporada al Derecho interno. Nótese que esta situación es de tal entidad, que el Tribunal ni siquiera puede hacer control preventivo de la misma, debiendo esperar la respectiva implementación normativa por parte del Congreso $^{83}$. Aunque esta autolimitación en el control preventivo ha sido matizada en un caso posterior ${ }^{84}$, la distinción self-executing y non-selfexecuting ha sido llevada de este modo al extremo por nuestro Tribunal Constitucional $^{85}$.

Ahora bien, más allá del efecto extremo otorgado a la referida clasificación por la jurisprudencia de nuestros tribunales, el concepto mismo de autoejecutabilidad - esto es, cuándo una norma es o no es autoejecutable - no es en absoluto claro en nuestro Derecho. De una lectura atenta de los fallos antes citados puede notarse que los únicos criterios utilizados son el "carácter programático" de las normas con-

${ }^{83}$ A favor de este criterio del Tribunal, Carlos Carmona Santander, "Comentarios a la Sentencia del Tribunal Constitucional sobre el Convenio $\mathrm{N}^{\circ} 169$ sobre Pueblos Indígenas", 2001, pp. 155-156. En contra, Teodoro Ribera Neumann, "El Derecho Internacional en la Jurisprudencia del Tribunal Constitucional Chileno”, 2001, pp. 59-61.

${ }^{84}$ Sentencia de fecha 5 de septiembre de 2003, Rol 383, Requerimiento contra el Acuerdo que Aprueba la Convención Interamericana sobre Desaparición Forzada de Personas, considerando $4^{\circ}$ (que afirma que el Tribunal puede igualmente declarar la inconstitucionalidad de las normas no autoaplicables).

${ }^{85}$ En Estados Unidos, la asimilación de la calidad de non-self-executing y la no incorporación del tratado al Derecho interno es materia muy discutida. Ahora bien, la corriente que afirma dicha asimilación es fuerte. Sobre este punto véase Iwasawa, n. 79, pp. 639-640 y 644, citando numerosa jurisprudencia y doctrina. Una de las facetas más complicadas que se derivan de esta asimilación es el poder interpretativo de un tratado non-self-executing respecto al ordenamiento interno. Véanse Jordan J. Paust, "Self-Executing Treaties", 1988, pp. 781-782, y más en general David Sloss, "The Domestication of International Human Rights", 1999. En Chile, en contra de esta asimilación, véase Infante Caffi, n. 72, p. 282, y Humberto Nogueira Alcalá, "Los Tratados Internacionales en el Ordenamiento Jurídico Chileno", 1996. 
templadas en el tratado, si las normas "se bastan a sí mismas" y, por último, el hecho que el tratado llame a su implementación ulterior ${ }^{86}$.

De esta forma, en Chile los criterios de autoejecutabilidad no resultan nada claros. El comentario crítico de Steinhardt es plenamente aplicable a nuestra jurisprudencia: "los tribunales no quieren decir nada consistente cuando declaran que un tratado es no autoejecutable" ${ }^{87}$. En todo caso, esto no es una sorpresa, dado el papel que juega el elemento político en la determinación de esta cuestión ${ }^{88}$. Y, por lo demás, esta forma de inaplicación de tratados por vía judicial no es una mala idea: el ordenamiento interno no queda entregado sin más a los negocios, buenos o malos, que puedan hacer los representantes del Estado en el plano internacional.

\section{II.c. Conflicto entre el Derecho internacional y el Derecho interno. El caso especial de los derechos humanos}

Pero ¿qué pasa si, aceptada la incorporación del Derecho internacional al Derecho interno, se produce una situación de conflicto de normas? Esta pregunta esconde en realidad cuatro problemas que requieren tratamiento separado. Primero, la interpretación del Derecho interno conforme al Derecho internacional. Segundo, el conflicto específico entre normas del Derecho consuetudinario internacional y del Derecho interno. Tercero, el mismo conflicto pero entre tratados internacionales y el Derecho interno. Y cuarto, el caso especial de tratados de derechos humanos, incluyendo el conflicto entre aquéllos y la Constitución.

${ }^{86}$ En Estados Unidos, de conformidad con el Restatement (Third) of Foreign Relations Law of the United States, §111, un acuerdo internacional no es self-executing si: a) el acuerdo manifiesta la intención de las partes en el sentido de que el mismo no se transforme efectivamente en Derecho interno sin la correspondiente implementación legislativa; b) si el Senado al dar su consentimiento al tratado, o el Congreso por una resolución, requieren normativa interna de implementación; c) si la implementación legislativa es requerida por la Constitución.

${ }^{87}$ Ralph G. Steinhardt, International Civil Litigation: Cases and Materials on the Rise of International Law, 2002, p. 244. Véase también, Iwasawa, n. 79, p. 631.

${ }^{88}$ Así lo defiende además Von Bogdandy, n. 59, p. 412: "La pregunta sobre el efecto directo no debe ser discutida sobre criterios de determinación ni tampoco considerada como una materia de carácter técnico. A lo menos desde una perspectiva constitucional, resulta preferible plantear una respuesta basada en la interacción de principios constitucionales tales como cooperación internacional, autodeterminación, subsidiariedad, certeza e igualdad jurídica". 
En relación con la interpretación del Derecho interno conforme al Derecho internacional — que permite salvar conflictos aparentes - hay comentaristas nacionales que afirman esta tesis. Según Benadava, la base de esta doctrina se debe al hecho de que "no es dable presumir que la intención del legislador haya sido infringir las obligaciones internacionales de su Estado"89. En cuanto a jurisprudencia, hasta 1962, el mismo Benadava señalaba que no había declaraciones judiciales sobre esta materia ${ }^{90}$ y en su trabajo de 1992 no menciona tampoco ningún pronunciamiento judicial $^{91}$. Seguimos sin conocer ningún fallo en tal sentido.

En cuanto a los conflictos entre el Derecho internacional consuetudinario y el Derecho interno, la posición clásica ya citada sostiene que el primero ocupa una función supletoria respecto de la ley y que, por ende, está a merced de la voluntad del legislador ${ }^{92}$. En otras palabras, el Derecho internacional consuetudinario se aplica sólo si no existe conflicto con las normas legales domésticas ${ }^{93}$. Ahora bien, la jurisprudencia ha adoptado también esta tesis, pero se ha mostrado vacilante ${ }^{94}$. En el famoso pero excepcionalísimo caso de los barcos daneses - Lauritzen con Fisco ${ }^{95}$ - la Corte Suprema se aventuró a afirmar que "aún en el supuesto de que pudieren tener aplicación las leyes internas los principios del derecho internacional tienen prevalencia en estos casos como se verá oportunamente" ${ }^{\prime \prime}$.

${ }^{89}$ Benadava, n. 69 ("Las Relaciones entre...) p. 13. La misma idea la reitera en su Manual, n. 77, p. 73: "El juez nacional debe tratar de evitar un conflicto entre la norma internacional y la norma interna dando a la norma interna una interpretación que la concilie con la norma internacional, ya que no es de presumir que el Legislador haya querido infringir el derecho internacional".

${ }^{90}$ Véase Benadava, n. 69 ("Las relaciones entre...) p. 13.

${ }^{91}$ Ibíd. pp. 26-27.

92 Ibíd. pp. 2-20. Específicamente, en la página 14 afirma que "en el foro interno el tribunal debe aplicar la ley interna (su ley) aún si es contrario al derecho internacional".

${ }^{93}$ Véase Gaete, n. 69, p. 269.

${ }^{94}$ Gaceta de los Tribunales, 1949, segundo semestre, pp. 443-445; Contra Eulogio Avilez Jara, Revista de Derecho y Jurisprudencia, T. LVI, $2^{\mathrm{a}}$ Parte, Sección 4a ${ }^{\mathrm{a}}$, p. 64, 1959.

${ }^{95}$ Lauritzen con Fisco, Revista de Derecho y Jurisprudencia, T. LII, $2^{\mathrm{a}}$ parte, Sección $1^{\mathrm{a}}$, p. 478 (1955).

${ }^{96}$ Ibíd., p. 485. Otra sentencia en el mismo sentido, Contra Eulogio Avilez Jara, n. 94. Asimismo, Manuel Ballesteros, La lei de Organización i Atribuciones de los Tribunales de Chile, 1890, p. 571, afirma en este clásico trabajo que: "I con sólo ser un cuerpo de doctrinas, el derecho internacional es sin embargo de aplicación preferente en las leyes positivas de carácter interno, en aquellas cuestiones regidas por él”. 
Por su parte, el problema de los conflictos entre ley y tratado 97 también es motivo de gran controversia tanto entre nuestros comentaristas como en nuestra jurisprudencia ${ }^{98}$. A veces se oye argumentar que los tratados son superiores a la ley, por no ser posible derogar una norma bilateral de manera unilateral, como asimismo por impedirlo el artículo 27 de la Convención de Viena sobre el Derecho de los Tratados ${ }^{99}$. Algunos autores señalan incluso que el nuevo artículo $54 \mathrm{~N}^{\circ} 1$ inciso $5^{\circ}$ de la Constitución ${ }^{100}$ daría respaldo a esta tesis ${ }^{101}$.

Pero quienes defienden esta tesis en base a los argumentos indicados asumen la respuesta que buscan, pues parten del supuesto que el Derecho chileno no distingue entre efecto externo y efecto interno de los tratados, invocando directamente el propio Derecho internacional al respecto. En nuestra opinión, Chile es un país que puede caracterizarse como dualista moderado, con lo que la ineficacia y/o invalidez en el plano interno no guardan una relación necesaria e indispensable con la eficacia e inderogabilidad en el plano internacional.

Esto significa que el Estado mantiene la capacidad de inaplicar un tratado en el plano interno, tanto por ley posterior, por declaración de no autoejecutabilidad — que corresponde a cualquier tribunal- como

${ }^{97}$ Para estos efectos, se asume que el tratado ha sido ratificado, promulgado y publicado, y que no ha sido declarado inconstitucional en control preventivo por el Tribunal Constitucional.

${ }^{98}$ Véase Benadava, n. 69 ("Las Relaciones entre...), pp. 25-27.

${ }^{99}$ Se basan en el argumento de la validez externa para demostrar efectos internos los siguientes autores: Nogueira Alcalá, n. 85, p. 348; Guillermo Bruna Contreras, "Los Tratados Internacionales en la Constitución de 1980: Jurisprudencia de la Década de 1981-1989", 2003; Jorge Tapia Valdés, "Efectos de los Tratados sobre Derechos Humanos en la Jerarquía del Orden Jurídico y en la Distribución de Competencias: Alcances del Nuevo Inciso Segundo del Artículo 5 de la CPR de 1980", 2003; Carlos Andrade Geywitz, "La Reforma Constitucional del año 1989 al Inciso $2^{\circ}$ del Artículo $5^{\circ}$ de la Constitución: Sentido y Alcance de la Reforma”, 2003; Emilio Pfeffer Urquiaga, "Los Tratados Internacionales sobre Derechos Humanos y su Ubicación en el Orden Normativo Interno", 2003; Miguel Ángel Fernández González, "Visión Prospectiva en Relación con la Regulación Constitucional de los Tratados Internacionales", 2003; Ana María García Barzelatto, "Control de Constitucionalidad de los Tratados Internacionales con Especial Referencia al Control Represivo", 2007.

${ }^{100}$ Esta norma dispone lo siguiente: "Las disposiciones de un tratado sólo podrán ser derogadas, modificadas o suspendidas en la forma prevista en los propios tratados o de acuerdo a las normas generales de derecho internacional".

101 Véanse Salinas, n. 36, p. 496; Marisol Peña Torres, "Control de Constitucionalidad de los Tratados Internacionales: La Experiencia Chilena Un Año Después de la Reforma de 2005”, 2007; y García, n. 99, pp. 507-508 y 509. 
también por sentencia del Tribunal Constitucional en control represivo. Conforme a esta interpretación, el artículo $54 \mathrm{~N}^{\circ} 1$ inciso $5^{\circ}$ de la Constitución es coherente con el artículo 27 de la Convención de Viena, y sólo se refiere al plano internacional ${ }^{102}$. La misma interpretación resguarda también la diferencia entre tratados de derechos humanos y tratados "ordinarios", sin producir una equivalencia normativa entre los artículos $5^{\circ}$ y $54 \mathrm{~N}^{\circ} 1$ inciso $5^{\circ}$ de la Constitución ${ }^{103}$, y se impide que el Presidente pueda inhabilitar al Congreso mediante la celebración de "tratados simplificados" o "acuerdos ejecutivos" (esto es, aquellos en los que no participa el Congreso) ${ }^{104}$. Por último, el propio Tribunal Constitucional ha señalado que las cosas no han cambiado en esta materia con motivo de la Reforma Constitucional del $2005^{105}$.

Este dualismo moderado difícilmente puede ser disputado si se acepta, primero, la necesidad de promulgación y publicación de los tratados para su vigencia interna - lo que implica una fecha de vigencia interna distinta de la del plano internacional, que corresponde a la ratificación del tratado-; segundo, el requisito que los tratados sean autoaplicables - que constituye una evidente forma de inaplicación interna-; y tercero, la potestad del Tribunal Constitucional de declarar

102 Esto queda claro al contrastar la Constitución con el texto original que se propuso en la moción que dio lugar a la reforma: "Los tratados internacionales, una vez promulgados y publicados, formarán parte del ordenamiento jurídico de la República y una vez en vigor, prevalecerán sobre las leyes y otras normas de menor jerarquía. Sus disposiciones sólo podrán ser derogadas, modificadas o suspendidas en la forma prevista en los propios tratados o de acuerdo a las normas generales de Derecho Internacional". Es significativo que este texto no haya sido aprobado. Véase Emilio Pfeffer Urquiaga, Reformas Constitucionales 2005, Antecedentes, Debates, Informes, 2005. En contra de la tesis que aquí se presenta - y por un dualista moderado-, véase Teodoro Ribera Neumann, "La Incorporación de los Tratados Internacionales al Orden Jurídico Interno", 2007, p. 519.

${ }^{103} \mathrm{Si}$ los tratados ordinarios posteriores son inderogables, la situación de los tratados ordinarios es esencialmente la misma que la de los tratados de derechos humanos. Esta equivalencia no se corresponde con nuestro texto constitucional, que otorga a estos últimos tratados un estatus especialísimo en su artículo $5^{\circ}$.

${ }^{104}$ Los tratados simplificados o acuerdos ejecutivos son, ante el Derecho internacional y la Convención de Viena —en particular su artículo $2^{\circ}$ - , tan tratados como los tratados ratificados por el Congreso. De seguirse la tesis que aquí se rebate, un acuerdo simplificado o acuerdo ejecutivo sería inderogable en el plano interno por ley posterior, quedando el Congreso inhabilitado.

105 Tribunal Constitucional, Control de constitucionalidad del proyecto de ley, aprobado por el Congreso Nacional, que modifica la Ley $N^{\circ}$ 17.997, Orgánica Constitucional del Tribunal Constitucional, sentencia de fecha 5 de agosto de 2009, Rol 12882009, 25 de agosto de 2009, considerando $46^{\circ}$. 
inaplicable una disposición de un tratado ${ }^{106}$ — pues en dicho caso, a pesar de la inaplicabilidad, el país seguirá obligado en el plano internacional (salvo inconstitucionalidad manifiesta).

Por lo tanto, en cuanto a su jerarquía, consideramos que la tesis tradicional que postula la asimilación normativa entre los tratados y la ley es la posición correcta en nuestro sistema constitucional ${ }^{107}$. De ello y de la ausencia de competencias materiales reservadas a los tratados se sigue que en Chile corresponde aplicar la regla lex posteriori derogat priori $^{108}$. Por el contrario, no parece políticamente conveniente situar a los tratados ordinarios por sobre la ley. Sólo una visión naïve del Derecho internacional podría querer inhabilitar permanentemente al Congreso en el ejercicio de su labor legislativa. En nuestra opinión, la tesis de la primacía de la norma posterior funciona perfectamente bien y no vemos razón para alejarse de ella: por una parte los tratados nuevos derogan el Derecho interno y, por otra parte, los tratados vigentes sólo pueden ser inaplicados internamente mediante una ley categórica en tal sentido $^{109}$. De este modo, el Congreso, órgano democrático por excelencia, retiene el control final sobre el contenido normativo del ordenamiento jurídico chileno.

Los tratados relativos a derechos humanos requieren tratamiento especial en este punto, porque así lo dispone la propia Constitución. El artículo $5^{\circ}$ inciso $2^{\circ}$ establece esta calidad normativa especial, la que en todo caso no exige, en nuestro concepto, que se les otorgue a estos tratados la jerarquía de supra-legal. Metodológicamente nos parece inapropiado crear categorías que no sólo no se ajusten al texto constitu-

${ }^{106}$ Así lo declaró el Tribunal Constitucional, ibíd., considerandos $35^{\circ}$ y ss.

107 Por todos, véase Salvador Mohor Abuauad y Gustavo Fiamma Olivares, "La Jerarquía Normativa de los Tratados Internacionales", 1994.

${ }^{108}$ Véase Orrego y Orrego, n. 69, pp. 46-47. Véase también Federico Duncker Biggs, Derecho Internacional Privado, 1956; Benadava, n. 69 (Derecho Internacional...), p. 74, y Benadava, n. 69 (“Las Relaciones entre...”), pp. 25-27. En cuanto a jurisprudencia, véase Duncan Fox y Cía. con Dirección General de Impuestos Internos, Revista de Derecho y Jurisprudencia, T. XXX, $2^{\text {a }}$ parte, sección $1^{\mathrm{a}}$, p. 100, 1932. Ahora bien, hay un fallo de la Corte Suprema, no publicado, anterior a la Constitución de 1980, que niega a la ley posterior la facultad de derogar un tratado, citado por Benadava, n. 69 ("Las Relaciones entre...), p. 27. También en contra de la posibilidad que una ley posterior derogue o modifique un tratado, véase Nogueira Alcalá, n. 85, p. 348 y, después de la reforma del 2005, véanse los autores citados en la n. 101.

109 También puede ser inaplicado internamente por declaración de inaplicabilidad del Tribunal Constitucional, o por declaración de no-autoejecutabilidad de cualquier sentenciador. 
cional, sino que tampoco cumplen ninguna función necesaria (entia non sunt multiplicanda praeter necessitatem, o "no multiplicar los seres sin necesidad", como exige el principio de la "navaja de Ockam").

Muy en síntesis, la obligación de los órganos del Estado de respetar los derechos esenciales emanados de la naturaleza humana garantizados por los tratados internacionales implica una limitación constitucional al poder normativo del Congreso. Ni el Congreso ni ningún otro órgano estatal pueden entonces derogar o disponer la inaplicación interna de un tratado internacional de derechos humanos. Con ello, más allá de disquisiciones dogmáticas sobre la jerarquía, en la práctica, los tratados internacionales quedan en una posición superior a las leyes ordinarias, pues por una parte derogan el Derecho interno anterior y, por otra parte, no son derogables por la actividad normativa posterior del Congreso Nacional.

Compartimos así la tesis "infra-supra" de Bertelsen"110, aunque no en un sentido dogmático sino en uno práctico. Decimos práctico porque lo que define este supra es el hecho de que una ley posterior contraria a un tratado internacional sobre derechos humanos es inconstitucional por vulnerar el artículo $5^{\circ}$ de la Carta Fundamental, y no, por el contrario, por una supuesta "naturaleza jurídica" del tratado en sí. En definitiva, los tratados de derechos humanos tienen, en nuestro concepto, la misma jerarquía interna que la ley, pero gozan de la protección constitucional de inderogabilidad o no-inaplicación interna.

Como corolario de lo anterior, la correcta interpretación del artículo $5^{\circ}$ de la Constitución debe ser que los tratados de derechos humanos son siempre autoejecutables. Los tratados ratificados por Chile y que se encuentren vigentes en el orden internacional de acuerdo al Derecho internacional, obligan a todos los órganos del Estado. En materia de derechos humanos Chile es, entonces, un país monista. Más exactamente, en nuestro país existe un "acoplamiento" total, incluyendo autoejecutabilidad o efecto directo y supremacía, todo ello por expresa disposición del artículo $5^{\circ}$ de la Constitución. Como consecuencia, el Congreso, el Presidente y el Tribunal Constitucional carecen de las potestades necesarias para suspender o inaplicar tales normas en el Derecho interno.

${ }^{110}$ Véase Raúl Bertelsen Repetto, "Rango Jurídico de los Tratados Internacionales en el Derecho Chileno", 1996. 
Ahora bien, que un tratado sea autoejecutable no significa que los derechos humanos que contiene sean todos plenamente justiciables. $\mathrm{Y}$, a la inversa, las dificultades que puedan encontrarse en términos de justiciabilidad de un cierto derecho humano cuyo origen se encuentra en el Derecho internacional no ponen en duda su autoejecutabilidad. La teoría de la autoejecutabilidad es una decisión jurídico-política que impide que un tratado/norma se incorpore al orden interno; internamente no existe para todos los efectos prácticos. Pero de reconocerse su incorporación — como se sigue del artículo $5^{\circ}$ - la justiciabilidad de sus derechos debe ser evaluada conforme a las mismas reglas que aplican a los demás derechos fundamentales reconocidos por el orden interno. No vemos ninguna razón especial para que las soluciones adoptadas por el Derecho constitucional relativas al rol de los jueces frente a los derechos constitucionales de segunda y tercera generación no sean aplicables a los derechos humanos que encuentran su origen en el Derecho internacional $^{111}$.

Finalmente, en cuanto al caso de conflicto entre Constitución y tratados internacionales, consideramos que no puede sino afirmarse, en el plano interno, la prevalencia de la Constitución ${ }^{112}$. Consecuentemente con el principio de legitimidad democrática, la Constitución es el cuerpo que determina el ordenamiento jurídico nacional, así como la validez, eficacia y aplicabilidad de las normas en el plano interno, de modo que no puede pasarse por alto el sistema de competencias y jerarquías que ella establece ${ }^{113}$. Sólo nos remitimos a señalar que el reconocimiento de la "supremacía constitucional" es la posición dominante en la jurisprudencia ${ }^{114}$, aunque hay fallos y posiciones contrarios,

${ }^{111}$ Los derechos de segunda y tercera generación son, en la generalidad de los casos, mandatos dirigidos a los organismos políticos de la nación, a fin de que creen políticas públicas apropiadas a la luz de los fines y objetivos definidos por tales derechos. Qué rol corresponde a los tribunales de justicia cuando los órganos políticos no hacen su trabajo o lo hacen en forma incompleta o inapropiada - uno de los dilemas centrales del Derecho constitucional-, es un punto que escapa a este trabajo.

112 Ver n. 68, y texto y cita asociados.

${ }^{113}$ Lo cual es obviamente sin perjuicio de la responsabilidad del Estado por la violación de normas válidas en el ámbito internacional.

${ }^{114}$ Ver sentencia del Tribunal Constitucional, Requerimiento respecto del Estatuto de Roma de la Corte Penal Internacional, adoptado en dicha ciudad el 17 de julio de 1998 , Rol 346, 8 de abril de 2002 , considerandos $59^{\circ}$ a $75^{\circ}$. Véase también, sentencia Rol 1288-2009, n. 105, considerando $49^{\circ}$. 
incluyendo una nueva tendencia a aceptar la inaplicabilidad de normas legales que colisionan con tratados internacionales ${ }^{115 / 116}$.

II.d. ¿Es el Convenio 169 un tratado de derechos humanos, en los términos establecidos por el artículo $5^{\circ}$ de la Constitución?

Conforme al esquema teórico previamente presentado, resulta crucial determinar la naturaleza o estatus del Convenio 169, esto es, establecer si se trata o no de un tratado que regula "derechos esenciales emanados de la naturaleza humana" en los términos del artículo $5^{\circ}$ de la Constitución. Si bien el Convenio 169 es indudablemente un tratado internacional ${ }^{117}$ —esto es, un acuerdo internacional que rige las relaciones entre partes en la escena internacional ${ }^{118}$ _, la calidad de "tratado de derechos humanos" que habitualmente se le atribuye entre los expertos requiere de un análisis más cuidadoso ${ }^{119}$.

La primera cuestión a resolverse en este punto es una de Derecho aplicable. La pregunta por la naturaleza o estatus del tratado es idebe resolverse conforme al Derecho internacional o al Derecho constitucional chileno? Por cierto que la situación más frecuente es que no se produzca conflicto, estando ambos derechos de acuerdo en que un tratado se refiere a derechos humanos. Pero éste no es necesariamente el caso. En consecuencia, corresponde analizar la naturaleza del Convenio 169 tanto a la luz del Derecho internacional como del Derecho interno. Este análisis, en rigor, debe realizarse norma por norma ${ }^{120}$, lo que a efectos

115 Véase, por ejemplo, Corte Suprema, "c/Basclay Humberto Zapata Reyes y Osvaldo Enrique Romo Mena”, Rol 3452-2006, sentencia de fecha 10 de mayo de 2007, considerando $62^{\circ}$.

${ }^{116}$ En efecto, el Tribunal Constitucional ha declarado inaplicables normas legales por ser consideradas contrarias a la dignidad humana (art. $1^{\circ}$ de la Constitución), conclusión a la que se llega luego de contrastar dichas normas con tratados internacionales de derechos humanos. Véanse por ejemplo Requerimiento de inaplicabilidad presentado por Julio Magri Rabaglio, Rol 834-2007, 13 de mayo de 2008, C. 22 ; yequerimiento de inaplicabilidad por inconstitucionalidad del Juez Presidente del Juzgado de Familia de Pudahuel, Rol 1340-2009, 29 de septiembre de 2009, C. $9^{\circ}$.

${ }^{117}$ Véase OIT, Guía Corta, n. 50, p. 8.

118 Malcolm N. Shaw, International Law, 2003, p. 811; y Vaugham Lowe, International Law, 2007, p. 64.

${ }^{119}$ Véase, por ejemplo, Observatorio Ciudadano, "Las Implicancias de la Ratificación del Convenio 169 de la OIT en Chile. 2009” (Introducción).

${ }^{120}$ Véase Claudio Troncoso Repetto y Tomás Vial Solar, "Sobre los Derechos Humanos Reconocidos en Tratados Internacionales en la Constitución”, 1993, p. 696, y Cecilia Medina Quiroga, "El Derecho Internacional de los Derechos Humanos", 1996, p. 65. 
de lo que nos hemos propuesto en este trabajo exige enfocarse en los artículos 6,7 y 15 .

Este punto no es un mero academicismo. En nuestra opinión, desde una perspectiva internacional, los artículos 6, 7 y 15.1 del Convenio 169 constituyen derechos humanos colectivos o de tercera generación $^{121}$, pues se enmarcan dentro de los mencionados conceptos de autodeterminación, identidad y propiedad ${ }^{122}$. Ahora bien, no puede llegarse a la misma conclusión respecto del artículo 15.2 en lo que se refiere al derecho de los pueblos indígenas a "participar siempre que sea posible en los beneficios que reporten tales actividades [prospección y explotación de los recursos existentes en sus tierras]". Incluso partiendo de la base que los derechos contenidos en tratados de derechos humanos se presumen también de derechos humanos ${ }^{123}$, no creemos que la citada disposición lo sea.

Como hemos visto, desde una perspectiva internacional, el derecho de los pueblos indígenas sobre sus territorios y recursos naturales es un derecho humano en la medida en que se trate de un factor esencial de su identidad y forma de vida ${ }^{124}$. Como ha señalado el Comité de Derechos Humanos, los pueblos indígenas tienen un derecho humano a sus formas tradicionales de vida y subsistencia, lo que se extiende a aquellas actividades económicas que forman parte esencial de la cultura ${ }^{125}$. Así lo recoge explícitamente el artículo 13.1 del Convenio $169^{126}$. Por

${ }^{121}$ Relator Especial de Naciones Unidas sobre la situación de los derechos humanos y las libertades fundamentales de los indígenas, "Principios internacionales aplicables a la consulta en relación con la reforma constitucional en materia de derechos de los pueblos indígenas en Chile", 24 de abril de 2009, párrafo 6 ("La obligación de los Estados de consultar a los pueblos indígenas con carácter previo a la adopción de medidas legislativas, administrativas o políticas que afecten directamente sus derechos y sus intereses está firmemente asentada en el derecho internacional de los derechos humanos").

${ }^{122}$ Véase nuestro comentario en la n. 17.

123 Véase Medina, n. 120, p. 64.

124 Véase Anaya, n. 15, p. 106, "Por tanto, el Convenio 169 reafirma la noción promovida por la Comisión Interamericana de Derechos Humanos y por el Comité para los Derechos Humanos de la ONU respecto de que los indígenas como grupo tienen derecho a una continua relación con las tierras y los recursos naturales de acuerdo a patrones tradicionales de uso y ocupación" (traducción de los autores).

${ }^{125}$ Véase Comité de Derechos Humanos, Comentario General $N^{\circ} 23$, n. 23, No 7.

126 Artículo 13.1 del Convenio 169: "Al aplicar las disposiciones de esta parte del Convenio, los gobiernos deberán respetar la importancia especial que para las culturas y valores espirituales de los pueblos interesados revista su relación con las tierras o territorios, o con ambos, según los casos, que ocupan o utilizan de alguna manera, y en particular los aspectos colectivos de esta relación". 
ello, en nuestro concepto, el componente "derecho humano" sobre los recursos naturales se agota en las demás disposiciones — distintas a la participación en los beneficios- contenidas en los numerales 1 y 2 del artículo 15 del Convenio 169.

Más aún, es posible afirmar que, de acuerdo al propio Convenio 169 , la frase "siempre que sea posible" impide que este interés establecido en favor de los pueblos indígenas pueda ser calificado como un verdadero derecho subjetivo. No siendo un derecho subjetivo, mal podría ser un derecho humano. Así lo reconoce la propia Organización Internacional del Trabajo:

¿Quiere decir [la frase "siempre que sea posible"] que los gobiernos siempre mantienen el derecho a decidir si los pueblos indígenas y tribales se benefician o no de la explotación de los recursos naturales ubicados en sus tierras? Sí, quiere decir eso ${ }^{127}$.

Conceptualmente, el derecho a "participar siempre que sea posible en los beneficios que reporten tales actividades" corresponde a un ingreso establecido en favor de los pueblos indígenas por encima del pago de indemnizaciones por daños y perjuicios. Es un derecho que no se explica en virtud de la justicia correctiva, sino de la justicia distributiva. Se trata de una redistribución focalizada de recursos desde las empresas hacia los pueblos indígenas. Y resulta difícil concebir que una forma semejante de redistribución —que Tribe llama spot redistributions, quitar a A para dar a $\mathrm{B}^{128}$ — pueda ser un derecho humano.

Corresponde ahora volver nuestra mirada al Derecho chileno. ¿Son los derechos reconocidos por el Convenio 169 derechos emanados de la naturaleza humana, en los términos del artículo $5^{\circ}$ de la Constitución? En la doctrina chilena, Rodrigo Correa se ha referido a este punto. Su análisis parte por el contenido del artículo $5^{\circ}$ :

La interpretación del artículo 5 de la Constitución es compleja y desgraciadamente no contamos con documentos públicos de su génesis que ayuden a su esclarecimiento. Dos factores contribuyen a la complejidad de la disposición. Por una parte, no identifica cuáles son los derechos esenciales que emanan de la naturaleza humana. Por otra parte, tampoco identifica cuáles son los tratados internacionales que garantizan dichos derechos. En

${ }^{127}$ OIT, Guía Corta, n. 50, p. 25 (énfasis agregado).

${ }^{128}$ Véase Laurence H. Tribe, Constitutional Choices, 1985, p. 167. 
consecuencia, un tratado estará cubierto por el artículo 5 siempre que reconozca o regule derechos que emanen de la naturaleza humana. La fórmula empleada es ontológica y epistemológicamente exigente: requiere tanto que de la naturaleza humana emanan derechos, como la posibilidad de conocer la naturaleza humana ${ }^{129}$.

A partir de lo anterior, Correa concluye que el Convenio 169 "no es entonces de aquellos tratados a que se refiere el artículo 5 de la Constitución"130. En síntesis, su posición es que los derechos colectivos o de tercera generación no tienen cobertura en la citada disposición constitucional:

Si la idea de derechos que emanan de la naturaleza humana algún sentido tiene, ésta supone que dicha naturaleza es una y que es independiente del contexto cultural o de factores religiosos, sexuales, de edad, de raza, de clase u otros cualesquiera. El Convenio 169 consagra derechos a personas que se identifican por su adscripción a ciertos grupos culturales o étnicos que para efectos del mismo se denominan pueblos tribales y pueblos indígenas (art. $1 \S 1$ ). En otras palabras, el Convenio reconoce derechos a personas en razón de pertenecer a pueblos determinados, no en razón de ser individuos de la especie humana ${ }^{131}$.

Aunque se trata de una posición razonable, no compartimos la tesis de Correa. Nuestra divergencia se debe a una posición de respeto institucional por las interpretaciones constitucionales explícitas o implícitas que haga el Congreso Nacional, autoridad interpretativa central - aunque no única ni última - de la Constitución. Si el Congreso y el Presidente ratifican un tratado que conforme al Derecho internacional es de derechos humanos, debe entenderse que no han querido crear una situación de conflicto con el Derecho interno y que, por el contrario, estiman que dicho tratado contiene normas de derechos humanos para los efectos del artículo $5^{\circ 132}$. Si nuestros órganos colegisladores quisieran

${ }^{129}$ Rodrigo Correa G., "Informe de Constitucionalidad Convenio 169 sobre Pueblos Indígenas y Tribales en Países Independientes, de la OIT”, 2002, p. 2 (en adelante, Correa, "Informe de Constitucionalidad").

${ }^{130}$ Ibíd.

${ }^{131}$ Ibíd.

${ }^{132} \mathrm{Al}$ revisar la historia de la tramitación de la ratificación del Convenio 169 en el Congreso Nacional (Boletín 233-10), queda claro que en todo momento los parlamentarios tuvieron presente estar discutiendo un tratado sobre derechos humanos. Así, por 
evitar que un tratado o sus normas sean calificados como de derechos humanos a efectos del Derecho interno, podrían eventualmente incluir una declaración en tal sentido.

Sólo en casos límites, en los que claramente se haya excedido el ámbito de lo que generalmente se conoce como propio de los derechos humanos, podría el Tribunal Constitucional concluir que un tratado internacional de derechos humanos ratificado por Chile no cabe en el artículo $5^{\circ}$ de la Constitución. Y ciertamente el Convenio 169 no es uno de tales casos límites, pues el mismo, por las razones antes dadas, cabe dentro de un concepto y ámbito modernos de los derechos humanos, como es el caso de los derechos colectivos de tercera generación.

\section{II.e. ¿Es autojecutable el Convenio 169? ¿Es ello motivo de alarma?}

Tal como ya lo hemos señalado, los tratados de derechos humanos ratificados y vigentes no pueden ser excluidos del ordenamiento interno por la vía de una declaración de no-autoejecutabilidad. Conforme al artículo $5^{\circ}$ de la Constitución, "es deber del Estado respetar y promover" los derechos contemplados en tales tratados. Dado dicho deber constitucional, es contradictorio sostener que los mismos órganos estatales puedan exceptuarse de su cumplimiento por la simple vía de una declaración de no-autoejecutabilidad.

En consecuencia, en nuestra opinión, las normas del Convenio 169 se integran en principio al Derecho interno. Por ende, estimamos que el Tribunal Constitucional resolvió acertadamente cuando sostuvo que los artículos 6 y 7 son autoejecutables ${ }^{133}$, pero no así al declarar

ejemplo, en el informe emitido en primer trámite constitucional por la Comisión de Derechos Humanos, Nacionalidad y Ciudadanía, de la Cámara de Diputados, se señala que el Convenio "ha tenido también como antecedente numerosos otros pactos internacionales, precursores del reconocimiento de los derechos humanos de las minorías, los grupos étnicos y las poblaciones indígenas". Asimismo, en segundo trámite constitucional, la Comisión de Relaciones Exteriores del Senado informó que el fundamento del Convenio "[s]e halla en la Declaración Universal de Derechos Humanos, el Pacto Internacional de Derechos Económicos, Sociales y Culturales, el Pacto Internacional de Derechos Civiles y Políticos, y en aquellos instrumentos internacionales que persiguen prevenir la discriminación".

${ }^{133}$ Ibíd., C. $5^{\circ}, 6^{\circ}, 7^{\circ}$ y $8^{\circ}$. Véase también Decreto Supremo (Mideplan) № 124 , Reglamenta el Artículo 34 de la Ley $N^{\circ} 19.253$ a Fin de Regular la Consulta y la Participación de los Pueblos Indígenas, considerando $8^{\circ}$, "[q]ue una vez que el Convenio entre en vigencia, los artículos $6 \mathrm{~N}^{\circ} 1$ letra a) y $\mathrm{N}^{\circ} 2$, y $7 \mathrm{~N}^{\circ} 1$ oración segunda del Convenio 
que los artículos 14 y 15.2 no lo son ${ }^{134}$. Sólo compartimos esta última afirmación del Tribunal en lo que respecta al derecho a "participar siempre que sea posible en los beneficios que reporten tales actividades" contemplado en la segunda parte del artículo 15.2, por cuanto no es un derecho subjetivo, no es un derecho humano y no cumple los requisitos generales de autoejecutabilidad propios de los tratados internacionales.

Para terminar, es necesario hacer notar que la calificación de los derechos del Convenio 169 como derechos humanos autoejecutables, incorporados al ordenamiento interno y justiciables en los mismos términos de los demás derechos fundamentales de segunda y tercera generación, no debe ser motivo de alarma ${ }^{135}$. Al menos cinco razones concretas y pragmáticas así lo prueban. Primero, los derechos humanos son esencialmente razones para la acción política - una prohibición a la indiferencia de la acción política-, dirigidos al Congreso y al Ejecutivo y sólo indirectamente a los tribunales ${ }^{136}$. Los derechos humanos no convierten a la democracia en el gobierno de los jueces ${ }^{137}$.

Segundo, que un cierto derecho sea un derecho humano no significa que necesariamente deba prevalecer sobre todo otro derecho. Los derechos humanos están sujetos a los procesos de balanceo y ponderación característicos de la justicia constitucional. Así ha sido expresamente reconocido, por ejemplo, por la propia CIDH en materia de

$\mathrm{N}^{\circ} 169$ pasarán a formar parte de la legislación vigente, ya que dichas normas tienen el contenido y precisión necesarios que las habilita para ser aplicadas sin otros trámites como fuente del derecho interno" [en adelante, Reglamento de Consulta y Participación], y Tribunal Constitucional, sentencia de fecha 3 de abril de 2008, Rol 1050, Control de constitucionalidad del proyecto de acuerdo aprobatorio relativo al Convenio $N^{\circ} 169$ sobre pueblos indígenas, adoptado por la Organización Internacional del Trabajo, de 27 de junio de 1989 [en adelante, Sentencia Rol 1050].

${ }^{134}$ Véase Sentencia Rol 309, n. 82, considerandos $65^{\circ}$ y $70^{\circ}$.

135 Véase, por ejemplo, Lucas Sierra, "La Constitución y los Indígenas en Chile: Reconocimiento Individual y No Colectivo”, 2003, quien se muestra preocupado por el reconocimiento de derechos de carácter colectivo.

136 Como señalamos anteriormente, el rol que corresponde a los tribunales en caso de inacción, acción inoportuna o acción altamente inapropiada de los órganos públi$\cos$ - que no es otra cosa que uno de los problemas tradicionales del Derecho constitucional-, escapa a los límites de este trabajo.

${ }^{137}$ Como ha señalado la Corte Suprema norteamericana en uno de los casos más importantes del siglo XX, Chevron, USA Inc. v. Natural Resources Defense Council, Inc., 467 U.S. 837, 866 (1984), "los jueces — quienes no son electos- tienen el deber de respetar las opciones de política pública de aquellos que sí lo son" (traducción de los autores). 
conflictos entre propiedad indígena y propiedad privada ${ }^{138}$. En cuanto razones para la acción política, los derechos humanos están sujetos a la determinación concreta que decidan darle las autoridades políticas frente a las demás razones para la acción política que puedan existir.

Tercero, los derechos humanos con origen en el Derecho internacional - así como los derechos fundamentales a nivel interno- se articulan, en la gran mayoría de los casos, conforme a un complejo esquema de repartición de autoridad entre el Congreso y el Ejecutivo por un lado, y los tribunales por el otro. El esquema es de "dos velocidades". En general, es frecuente y también apropiado que los tribunales muestren un gran nivel de deferencia por las políticas públicas de implementación de los derechos humanos adoptadas por los gobiernos. Pero, al mismo tiempo, tampoco es raro encontrar "bolsones" de autoridad judicial, conforme a los cuales las cortes constitucionales e internacionales defienden asertivamente algunas dimensiones muy específicas y circunscritas (aunque a veces impredecibles) de los derechos ${ }^{139}$.

Cuarto, todo remedio institucional conlleva siempre riesgos o potenciales efectos adversos. La existencia de tales riesgos o efectos no constituye un argumento per se en contra del remedio, sino que es motivo de preocupación y monitoreo al momento del diseño e implementación del mismo. En tal sentido y desde una perspectiva pragmática y no conceptual, compartimos con Sierra su preocupación por el riesgo de coacción de los pueblos indígenas sobre sus miembros así como también el riesgo de inmovilidad económica que puede seguirse de una inadecuada legislación indígena que recoja derechos de segunda y tercera generación ${ }^{140}$. Pero el desafío es controlar y evitar tales riesgos, no usarlos como argumentos en contra de la acción política pro-indígena.

Por último, y volviendo a la recepción judicial de los derechos indígenas en nuestro país, la todavía escasa jurisprudencia de nuestros

138 Véase Caso Yakye Axa, n. 24, p. 149 ("Esto no significa que siempre que estén en conflicto los intereses territoriales particulares o estatales y los intereses territoriales de los miembros de las comunidades indígenas, prevalezcan los últimos por sobre los primeros."). Véase también Caso Sawhoyamaxa, n. 24, p. 138 ("Sobre el particular, la Corte ha señalado que cuando existan conflictos de intereses en las reivindicaciones indígenas, habrá de valorarse caso por caso la legalidad, necesidad, proporcionalidad y el logro de un objetivo legítimo en una sociedad democrática (utilidad pública e interés social), para restringir el derecho de propiedad privada, por un lado, o el derecho a las tierras tradicionales, por el otro").

139 Para un estudio del derecho de propiedad en estos términos, Véase Montt, n. 30 , pp. $165-229$.

${ }^{140}$ Véase Sierra, n. 135 , p. 23. 
tribunales superiores de justicia confirma que la incorporación de un tratado de derechos humanos indígenas de tercera generación no es motivo de alarma. Nuestros jueces no se inclinan hacia el peligroso activismo judicial que caracteriza a otros países latinoamericanos, sino que mantienen una actitud deferente que, al mismo tiempo, no duda en actuar frente a claras ilegalidades o arbitrariedades ${ }^{141}$. De hecho, el peligro a ratos pareciera ser el contrario, esto es, el bajo cumplimiento de los compromisos asumidos en el Convenio $169^{142}$.

\section{RESEÑA DE LA “CUESTIÓN INDÍGENA” EN CHILE}

Antes de analizar los artículos 6, 7 y 15 del Convenio 169, creemos indispensable presentar una reseña histórica de la "cuestión indígena" en nuestro país. A ratos y producto de la actual efervescencia de los conflictos territoriales en la zona sur, pareciéramos olvidar que dicha cuestión no es nueva en nuestra historia. Lo cierto es que ella se remonta a la llegada de los españoles al territorio, se prolonga a lo largo de todo el período pre-republicano y se perpetúa tras la fundación del Estado chileno hasta nuestros días.

No constituye una tarea fácil reseñar la historia de los pueblos originarios en su relación con la Corona española primero y con el Estado de Chile después. Al menos, existen ciertos hitos que permiten entender la situación actual del mundo indígena, el fundamento de sus demandas y de la legislación y las políticas públicas elaboradas a su respecto. Aunque existen diversos pueblos indígenas en el territorio patrio $^{143}$, nos centraremos aquí en el caso del pueblo mapuche. Su historia es la más documentada, es la etnia de mayor población y, en definitiva,

${ }^{141}$ Véase Corte de Apelaciones de Temuco, Linconao con Sociedad Palermo Limitada, Recurso de Protección Rol N ${ }^{\circ}$ 1773-2008, 16 de septiembre de 2009, confirmado por sentencia de la Corte Suprema, Rol 7287-2009, 30 de noviembre de 2009; y Corte Suprema, Alejandro Papic Dominguez con Comunidad Indígena Aimara Chusmiza y Usmagama, Recurso de Casación en el Fondo Rol 2840-2008, 25 de noviembre de 2009.

${ }^{142}$ En uno de los casos más relevantes en la materia, la Corte Suprema revocó, incorrectamente a nuestro juicio, un acertado fallo de la Corte de Apelaciones de Temuco. Véase Puelman Ñanco con Comisión Regional del Medio Ambiente Región de la Araucanía, Corte Suprema, 17 de mayo de 2010, Rol 1525-2010, y Corte de Apelaciones de Temuco, 21 de enero de 2010, Rol 1705-2009.

${ }^{143}$ El artículo $1^{\circ}$ de la Ley 19.253 de 1993 señala que "El Estado reconoce como principales etnias indígenas de Chile a: la Mapuche, Aimara, Rapa Nui o Pascuenses, la de las comunidades Atacameñas, Quechuas, Collas y Diaguita del norte del país, las comunidades Kawashkar o Alacalufe y Yámana o Yagán de los canales australes”. 
el pueblo que mayores puntos de conflicto presenta hoy. Además, el caso mapuche permite en buena medida ejemplificar lo que ha ocurrido con todos los pueblos indígenas, especialmente en materia de legislación y políticas públicas.

\section{III.a) Historia pre-republicana y temprana república}

La historia del conflicto mapuche comenzó con la llegada de los primeros conquistadores españoles a la zona de la Araucanía a mediados del siglo XVI, que pronto dio paso a la "Guerra de Arauco". Como es sabido, en esta guerra los mapuches ofrecieron una fuerte resistencia al ejército español, siendo sus mayores victorias la batalla de Tucapel (1553) y el alzamiento de Curalaba (1598).

En un hecho inédito en la historia de los reinos españoles en América, los mapuches lograron dar muerte a dos gobernadores de la Corona: Pedro de Valdivia y Martín García Oñez de Loyola. Ocurrido este último hecho y viendo los españoles que no les era posible penetrar y controlar los territorios situados al sur del Biobío, se dio inicio a una segunda etapa en su relación con el pueblo mapuche, denominada como el período de "La Frontera".

Durante el período de La Frontera, la relación español-mapuche se estructuró sobre la base de una lógica de acuerdos. En una época marcada por la política de los parlamentos se produjo una suerte de reconocimiento del "pueblo-nación" mapuche y de una frontera común entre ambas naciones ${ }^{144}$. En el primero de dichos parlamentos, el de Quilín o Quillín (1641), se reconoció la frontera en el río Biobío y el territorio del pueblo mapuche al sur de ese río. Los mapuches se comprometieron, por su parte, a considerar como enemigos a los enemigos de España y a permitir el ingreso de misioneros. Todos los parlamentos posteriores ${ }^{145}$ confirmaron en mayor o menor grado estos acuerdos, tomando como base lo allí acordado ${ }^{146}$.

144 Comisión de Verdad Histórica y Nuevo Trato, Informe de la Comisión de Verdad Histórica y Nuevo Trato, 2003, Volumen I, Primera parte, p. 362 [en adelante, ICVHNT-I.1].

145 Los siguientes parlamentos celebrados entre mapuches y españoles son el de Boroa de 1651, de Toltén de 1652, de Imperial de 1683, de Yumbel de 1692, de ChoqueChoque de 1695, de Negrete de 1726, de Tapihue de 1738 y 1746, de Salto del Laja de 1756, de Santiago de 1760, de Nacimiento de 1764, de Negrete de 1771, de Santiago de 1772, de Santiago y de Tapihue de 1774, de Lonquilmo de 1784 y de Negrete de 1793 y 1803.

146 José Bengoa, Historia del Pueblo Mapuche. Siglos XIX y XX, 2000, p. 36. 
Se ha señalado que estos parlamentos entre los mapuches y los españoles tendrían la naturaleza de verdaderos tratados internacionales entre naciones soberanas y que, al lograrse la independencia, la Araucanía se habría regido por tales tratados ${ }^{147}$. Incluso se ha postulado que tales tratados serían obligatorios e inmodificables para el propio Estado de Chile ${ }^{148}$. De acuerdo al informe de la Comisión de Verdad Histórica y Nuevo Trato, si bien estas tesis han sido desestimadas por los tribunales chilenos, los parlamentos "debieran ser tomados en cuenta como un antecedente de la mayor importancia frente a situaciones de controversia contemporánea"149.

Con la independencia se dio paso, en una primera etapa, a una valorización de los mapuches, considerándoselos como la encarnación del ideario de la libertad en contra del pueblo opresor extranjero ${ }^{150}$. El propio O'Higgins se refería en 1817 a los mapuches como "el lustre de la América combatiendo por su libertad"151. Con ello vino también un período de legislación "igualitarista" entre chilenos y mapuches, reconociéndoseles la calidad de ciudadanos en plenitud, no obstante que, a la vez, se regulaba su forma de vida con claros sesgos paternalistas. Así, el artículo $1^{\circ}$ el Decreto de $1^{\circ}$ de julio de 1813 - la primera legislación indígena del Estado chileno- estatuía que:

Todos los indios verdaderamente tales i que hoy residen en los que se nombran pueblos de indios, pasarán a residir en villas formales, que se erijirán en dos, tres, o mas de los mismos pueblos designados por una comisión, gozando de los mismos derechos sociales de ciudadanía que corresponde al resto de los chilenos.

\section{A su vez, el artículo $4^{\circ}$ disponía que:}

Cada indio tendrá una propiedad rural, ya sea unida a su casa, si es posible, i de nó, en las inmediaciones de la villa. De ella podrán disponer con absoluto i libre dominio; pero sujetos a los estatutos de policía i nuevas poblaciones, que podrán añadir o modificarse por la comisión.

${ }^{147}$ ICVHNT-I.1, n. 144, p. 366.

148 Véase Grupo Nizkor en http://www.derechos.org/nizkor/espana/doc/endesa/ negrete.html (última visita, 5 de noviembre de 2009).

${ }^{149}$ ICVHNT-I.1, n. 144, p. 369.

${ }^{150}$ Luego, en la llamada "Guerra a Muerte" entre patriotas y realistas, esta visión inicial fue cambiando como consecuencia de que los mapuches, en cumplimiento de lo acordado en los parlamentos con los españoles, lucharon junto a ellos en contra de los independentistas.

${ }^{151}$ Jorge Pinto R., "De la Inclusión a la Exclusión. La Formación del Estado, la Nación y el Pueblo Mapuche", 2003, p. 46, en ICVHNT-I.1, n. 144, p. 377. 
En la misma línea, el Bando Supremo de 4 de marzo de 1819, firmado por O'Higgins, repudia el trato dado por los españoles a los indígenas y los reconoce como ciudadanos chilenos, concediéndoles además el privilegio de la exención del pago de tributos ${ }^{152}$. Años más tarde, bajo el gobierno de Freire, se dictó la Ley de 10 de junio de 1823, que disponía que "lo actual poseído según lei por los indígenas, se les declare en perpetua y segura propiedad", de modo que "las tierras sobrantes se sacarán a pública subasta... para que... verificado su remate, se vendan de cuenta del Estado". De este proceso provienen los llamados "títulos de comisario", que han sido una de las más sólidas bases para la defensa de los actuales intereses indígenas.

\section{III.b) Comienzan los abusos}

Este primer período en nuestra historia republicana, caracterizado por un reconocimiento del pueblo mapuche y de su territorio, no fue muy prolongado. Las cosas comenzaron a cambiar debido a la presión por expandir el territorio chileno hacia el norte y hacia el sur. La siguiente etapa de la relación del Estado con el pueblo mapuche se refleja ya claramente en la Ley de 2 de julio de 1852, mediante la cual, por primera vez, se efectúa una declaración de soberanía sobre lo que tradicionalmente se consideraba territorio indígena, creándose la Provincia de Arauco, entre el río Biobío y el norte de la Provincia de Valdivia.

Ahora bien, como consecuencia de los abusos cometidos por los especuladores de tierras y de las denuncias efectuadas por los indígenas y algunos sacerdotes católicos, se dictó casi simultáneamente la Ley de 14 de mayo de 1853 , cuyo texto da cuenta de una incipiente política de protección:

152 El Bando Supremo del 4 de marzo de 1819 señalaba: "El gobierno español, siguiendo las máximas de su inhumana política, conservó a los antiguos habitantes de la América bajo la denominación degradante de naturales. Era esta una raza abyecta, que pagando un tributo anual, estaba privada de toda representación política y de todo recurso para salir de su condición servil. Las leyes de Indias corregían estos abusos disponiendo que viviesen siempre en clase de menores bajo la tutela de un funcionario titulado 'Protector General de Naturales'. En una palabra nacían esclavos, vivían sin participación de los beneficios de la sociedad y morían cubiertos de oprobio y miseria. El sistema liberal que ha adoptado Chile no puede permitir que esa porción de nuestra especie continúe en tal estado de abatimiento. Por tanto declaro que para lo sucesivo deben ser llamados CIUDADANOS CHILENOS, y libres como los demás habitantes del Estado, con quienes tendrán igual voz y representación...”. 
Toda compra de terrenos hecha a indíjenas o de terrenos situados en territorio de indíjenas debe verificarse con intervencion del Intendente de Arauco y del Gobernador de Indíjenas del territorio respectivo que el Intendente comisione para cada caso. La intervención del Intendente o del funcionario comisionado por él, tendrá por objeto asegurarse de que el indíjena que venda presta libremente su consentimiento, de que el terreno que vende le pertenece realmente i de que sea pagado o asegurado debidamente el pago del precio convenido.

Más adelante, durante el gobierno de José Joaquín Pérez y al mismo tiempo que Orélie Antoine de Tounens se autoproclamaba "Rey de la Araucanía y la Patagonia", se dio comienzo a la "Pacificación" u "Ocupación" de la Araucanía, comandada por el general Cornelio Saavedra. Como parte de este proceso, se dictó la Ley de 4 de diciembre de 1866, según la cual una "Comisión Radicadora" procedería a deslindar los terrenos pertenecientes a los indígenas, expidiéndose en su favor títulos de merced y agregándose que "se reputarán como terrenos baldíos i por consiguiente de propiedad del Estado, todos aquellos respecto de los cuales no se haya probado una posesion efectiva i continuada de un año por lo ménos".

De esta manera, se reemplazó el concepto de "territorio de indígenas" por el de "territorio de colonización"153, y se despojó en consecuencia a los mapuches de buena parte de sus tierras al negarles en los hechos la posibilidad de probar su posesión en la forma prevista por la ley. Esta misma Ley de 1866 creó la figura del "Protector de Indios", letrado encargado de cumplir las funciones que la Ley de 14 de mayo de 1853 había entregado a los intendentes y gobernadores, representando a los indígenas "en todas las circunstancias que se ofrezcan, i especialmente en el deslinde de sus posesiones i en todos los contratos traslaticios de dominio".

Buena parte de los conflictos actuales proviene de los abusos observados en la implementación de la política de reducciones y de concesión de títulos de merced iniciada con la dictación de la Ley de 1866 y que continuó con la legislación posterior basada en ella ${ }^{154}$. No fue

${ }^{153}$ ICVHNT-I.1, n. 144, p. 388.

${ }^{154}$ Ibíd. p. 392. En cuanto a legislación posterior, se puede citar como ejemplo a la Ley de 4 de agosto de 1874 que fomentó la colonización de tierras indígenas: "Artículo 11. A los particulares que quieran establecer colonias por su cuenta en el territorio indígena, se les concederá hasta ciento cincuenta hectáreas de terreno plano o lomas o 
infrecuente que los deslindes señalados a favor de los indígenas en los títulos de merced no fueran respetados por los propietarios colindantes, que se repartieran tierras a particulares donde ya existían títulos de merced, que se entregaran a los mapuches terrenos más pequeños que los que se consignaban en los títulos y que se utilizara una serie de fraudes para privar a los indígenas de las propiedades que previamente se les había reconocido ${ }^{155}$.

Todas estas prácticas abusivas y fraudulentas fueron consignadas ya hacia el final del proceso de radicación, por los protectores de indios y por la Comisión Parlamentaria de Colonización formada en 1911 con la participación de senadores y diputados que viajaron a la zona de Arauco para cerciorarse de la veracidad de las denuncias hechas por los mapuches. Resulta interesante destacar que en el informe de dicha Comisión se consignó lo siguiente:

Muchos reclamos son justificados: que los indígenas suelen ser víctimas de gentes inescrupulosas y á veces de inhumanas, que los hostilizan, los maltratan ó se valen de argucias abogadiles para despojarlos de lo suyo; que su radicación se hace con despacio, (...) que otros son perseguidos por vías de hecho o judicialmente, por detentadores injustos de tierras del Estado, que aspiran por este medio a afirmar sus pretensiones de dominio sobre las mismas; que algunos concesionarios tratan de desalojar sin razón á personas establecidas dentro de sus concesiones; que hay ocupantes que se instalan donde no les corresponde; y que la acción de las autoridades aparece en ciertos casos amparando, más las arbitrariedades del fuerte que los derechos del débil" 156 .

El proceso de radicación iniciado por la Ley de 1866 concluyó en 1929. De acuerdo a la Comisión de Verdad Histórica y Nuevo Trato, como consecuencia de esta política indígena el Estado habría hecho entrega de 3.078 títulos de merced, que a la época de su concesión equivalían a 475.194 hectáreas, "favoreciendo" a 77.751 indígenas. Según otros datos, se habrían entregado 2.918 títulos a 82.629 personas, por un

bien el doble en las serranías o montañas, por cada familia inmigrante de Europa o de los Estados Unidos de Norteamérica, previas las condiciones que estableciere el Presidente de la República en los respectivos contratos".

${ }^{155}$ Véase ICVHNT-I.1, n. 144, p. 404.

156 "Comisión Parlamentaria de Colonización, Informe, Proyectos de Ley y Actas de las Sesiones y Otros Antecedentes", XII, citado en ICVHNT-I.1, n. 144, p. 402. 
total de 510.386 hectáreas, lo que equivale al 6,39\% del territorio hasta entonces ocupado por los mapuches, entre las provincias de Arauco por el norte y Osorno por el sur ${ }^{157}$.

\section{III.c) El divisionismo}

Con el término de la década del 1920 se inicia una nueva etapa de nuestra legislación indígena. A esta nueva legislación podría llamársele "divisionista", porque impulsó la partición de las comunidades indígenas ya radicadas. El fundamento de esta nueva política indígena era la idea de que buena parte de los males que aquejaban al pueblo mapuche derivaban de la indivisión de la tierra, idea cuyo origen se encuentra, en general, en el Código Civil y en el pensamiento de Bello.

Este período comienza con la Ley 4.169 de 1927, dictada bajo el primer gobierno de Ibáñez, que creó el llamado "Tribunal especial de división de comunidades indígenas". Aunque el Tribunal debía en primer lugar hacer la división de las comunidades que así lo solicitasen, también podía efectuarla de oficio en determinados casos. Posteriormente, conforme a la modificación introducida por el Decreto Supremo $\mathrm{N}^{\circ} 4.111$ de 1931, el Tribunal podía realizar la partición únicamente a petición de un tercio de los comuneros. Cabe notar que la Ley 4.169 permitía a los indígenas enajenar libremente sus hijuelas, salvo algunas excepciones que en todo caso desaparecían al cabo de 10 años de concluida la partición.

El 11 de febrero de 1930 se dictó la Ley 4.802, que puso fin a la figura del Protector de Indígenas, a la Comisión Radicadora de Indígenas y, por ende, a la entrega de títulos de merced. Esta nueva reglamentación creó los "Juzgados de Indios", a los que se entregó la facultad de conocer de la división de las comunidades mapuches. Los indígenas podían gravar o enajenar sus propiedades siempre que contaran con autorización del Juez de Indios, aunque sólo cuando hubieren transcurrido diez años desde la fecha de la terminación de la partición.

Otro hito de este período es la Ley 14.511 de 1961, llamada "Ley de Propiedad Indígena”. Esta ley, entre otras cosas, amplió el número de Juzgados de Letras de Indios a fin de garantizar el acceso a la justicia, estableció un nuevo procedimiento para la liquidación de las comunida-

${ }^{157}$ ICVHNT-I.1, n. 144, pp. 420-421. 
des (ratificando la norma ya existente, que exigía acuerdo previo de un tercio de los comuneros), creó normas sobre crédito indígena, prohibió la enajenación de los terrenos indígenas durante su indivisión y permitió gravarlos únicamente a favor de ciertas instituciones, haciendo extensiva tal restricción a las hijuelas resultantes de la división.

Cabe notar que la legislación divisionista tuvo "éxito" en lo que respecta a su objetivo de terminar con las comunidades indígenas. Existen antecedentes de que surgieron 13.000 propietarios indígenas regidos por el Derecho común, todos ellos derivados de la liquidación de 793 de los 3.078 títulos de merced concedidos, equivalentes al 25\% de los terrenos indígenas ${ }^{158}$.

\section{III.d) Reformas y contrarreformas}

El proceso de Reforma Agraria partió primero con la dictación de la Ley 15.020, bajo el gobierno de Jorge Alessandri, y continuó luego con la Ley 16.640, durante la presidencia de Eduardo Frei Montalva. Si bien parece haber favorecido en algún grado menor a los mapuches, este proceso no estuvo basado en su especificidad étnica ni en sus problemas concretos en tanto pueblo indígena. Pero igualmente implicó una revitalización de las reivindicaciones de tierras y del movimiento indígena.

Por su parte, Salvador Allende asumió una agenda más proindígena. Como candidato firmó el acuerdo en el Cerro Ñielol en 1964, obligándose a emprender cambios legales favorables a los pueblos indígenas, y su programa de gobierno incluía entre sus puntos la defensa de la causa indígena. En concreción de este programa, a fines de 1972 entró en vigencia la Ley 17.729, que derogó la anterior Ley de Propiedad Indígena (Ley 14.511).

Dos innovaciones de esta ley merecen ser destacadas: por primera vez se define legalmente lo que debe entenderse por "indígena" 159 , y por primera vez también se contempla un mecanismo de recuperación de tierras indígenas correspondientes a títulos de merced, a través de la

158 Martín Correa et al., "La Reforma Agraria y las Tierras Mapuches. Chile 1962-1975", p. 31, en ICVHNT-I.1, n. 144, p. 436.

${ }^{159} \mathrm{El}$ artículo $1^{\circ} \mathrm{N}^{\circ} 3$ de la Ley 17.729 señala: "Se tendrá por indígena... a la persona... que, habitando en cualquier lugar del territorio nacional, forme parte de un grupo que se exprese habitualmente en un idioma aborigen y se distinga de la generalidad de los habitantes de la República por conservar sistemas de vida, normas de convivencia, costumbres, formas de trabajo o religión, provenientes de los grupos étnicos autóctonos del país". 
expropiación. Así, por este medio, entre el 4 de noviembre de 1970 y el 11 de septiembre de 1973, se expropiaron a favor o con participación mapuche, 138 predios, con una superficie de 132.116 hectáreas $^{160}$. Por otra parte, esta ley suprimió los juzgados de indios, creó el Instituto de Desarrollo Indígena y elevó el quórum para la liquidación y partición de las comunidades de un tercio a la mayoría absoluta de los comuneros.

Como es sabido, el gobierno militar impulsó un proceso de contrarreforma agraria. En materia indígena, dicha contrarreforma implicó la devolución del 64,7\% de las tierras anteriormente expropiadas en favor de los mapuches, el remate de tres predios ocupados por los mismos (correspondientes a una superficie de 1.478 hectáreas) y la parcelación de 63 predios (correspondientes a una superficie de 53.204,88 hectáreas ${ }^{161}$ ).

Conforme a una idea de desarrollo indígena no colectivista, el Decreto Ley 2.568 de 1979 buscó terminar con el régimen de propiedad indígena, fomentando la liquidación de las comunidades y la instauración de propiedades individuales ${ }^{162}$. Para tales efectos, estableció un procedimiento de división que podía comenzar a petición del Abogado Defensor de Indígenas ante el juez de letras competente o a requerimiento escrito de cualquiera de los ocupantes o comuneros efectuado al director regional de INDAP (Instituto de Desarrollo Agropecuario) ${ }^{163}$. Como consecuencia, entre 1979 y 1986, 1.739 comunidades, equivalentes al 59,6\% del total y a 287.849,41 hectáreas, fueron divididas entre las provincias de Arauco y Osorno ${ }^{164}$.

\section{III.e) Situación actual: la Ley 19.253}

A pocos días de la elección presidencial de 1989, el entonces candidato Patricio Aylwin suscribió con los representantes de diversas organizaciones indígenas el llamado "Compromiso de Nueva

${ }^{160}$ Véase ICVHNT-I.1, n. 144, p. 447.

${ }^{161}$ Correa et al., n. 158, p. 259, citado en ICVHNT-I.1, n. 144, p. 448.

162 El Preámbulo del DL 2.568 señalaba como inspiración las siguientes consideraciones: " $1{ }^{\circ}$. La necesidad de terminar con la discriminación de que han sido objeto los indígenas, situación que la legislación vigente no ha permitido superar; $2^{\circ}$. El hecho que la denominada 'Propiedad Indígena' ha sido fuente de numerosos problemas, los que han constituido serias barreras para el progreso de la población indígena; $3^{\circ}$. La aspiración evidente de los indígenas de llegar a ser propietarios individuales de la tierra, comprobada por las divisiones de hecho que entre ellos han efectuado...".

${ }^{163}$ El Decreto Ley 2.568 suprimió el Instituto de Desarrollo Indígena y creó el Instituto de Desarrollo Agropecuario (INDAP).

${ }^{164}$ Archivo de Asuntos Indígenas-Conadi citado en ICVHNT-I.1, n. 144, p. 39. 
Imperial"165. En este instrumento las organizaciones indígenas se comprometieron a apoyar al futuro gobierno y a canalizar sus demandas a través de las instancias y mecanismos institucionales. Por su parte, la Concertación se comprometió, entre otras cosas, a obtener el reconocimiento constitucional de los pueblos indígenas y de sus derechos económicos, sociales y culturales fundamentales, a la creación de la Conadi (Corporación Nacional de Desarrollo Indígena) y de un Fondo de Etnodesarrollo para promover la política indígena.

Siguiendo los compromisos adoptados en Nueva Imperial, el 21 de diciembre de 1990 el primer gobierno de la Concertación envió al Congreso Nacional el Convenio $169^{166}$. Con fecha 7 enero de 1991 envió también un proyecto de reforma constitucional para darles reconocimiento a los pueblos indígenas en la Carta Fundamental ${ }^{167}$. Y, finalmente, por Mensaje de 15 de octubre de 1991, mandó el "Proyecto de Ley Relativo a la Protección, Fomento y Desarrollo de los Pueblos Indígenas" que se convertiría en la actual Ley $19.253^{168}$.

Esta ley — que ha regido hasta nuestros días sin mayores alteraciones en su texto original - abarca la mayor parte de las materias que definen la "cuestión indígena" y de lo que han sido las reivindicaciones históricas de los pueblos originarios. Su análisis pormenorizado es complejo y excede el objetivo del presente trabajo, pero cabe destacar los siguientes aspectos de la ley:

- Define quiénes deben considerarse indígenas conforme a tres criterios: relación con la tierra indígena, apellido indígena y/o rasgos culturales indígenas y autoidentificación como indígena (artículo $2^{\circ}$ ).

165 Este Compromiso fue suscrito por Patricio Aylwin, como candidato a la Presidencia de la República de la Concertación de Partidos por la Democracia y por representantes de organizaciones indígenas mapuches, huilliches, aimaras y rapa-nui, presentes en el Encuentro Nacional de Pueblos Indígenas, realizado en Nueva Imperial el 1 de diciembre de 1989.

${ }^{166}$ Boletín $\mathrm{N}^{\circ} 233-10$.

167 Boletín $\mathrm{N}^{\circ}$ 513-07. El proyecto de reforma constitucional fue rechazado $\mathrm{y}$, aunque se han presentado otros nuevos proyectos para darles reconocimiento a los pueblos indígenas en la Constitución, éste aún no se ha concretado. Véanse Boletines Nos. 2360-07 de 6 de julio de 1999; 4069-07 de 10 de enero de 2006; 5324-07 de 6 de septiembre de 2007; 5427 de 30 de octubre de 2007 y 5522-07 de 23 de noviembre de 2007.

${ }^{168}$ Boletín $N^{\circ} 514-01$. 
- Define cuáles deben ser consideradas tierras indígenas conforme a cuatro categorías: 1) las que son actualmente ocupadas en propiedad o posesión por individuos o comunidades indígenas en base a los títulos que la misma ley enumera; 2) las que históricamente han ocupado y poseen las personas y comunidades indígenas, siempre que sean inscritas en el Registro de Tierras Indígenas; 3) las que proviniendo de los títulos y modos indicados previamente, se declaren de propiedad de personas o comunidades indígenas por los tribunales de justicia; y 4) las que los indígenas o sus comunidades reciban a título gratuito de parte del Estado (artículo 12).

- $\quad$ Establece restricciones a la enajenación y gravamen de las tierras indígenas (artículo 13).

- Reconoce la costumbre indígena como fuente de Derecho en materia civil y como antecedente para la aplicación de una atenuante o eximente de responsabilidad penal (artículo 54).

- Contempla la consulta a los pueblos indígenas respecto de materias que tengan "injerencia o relación con cuestiones indígenas" (artículo 34).

- Crea una serie de instituciones y mecanismos para la protección y promoción de los pueblos indígenas, entre ellos: 1) la Corporación Nacional de Desarrollo Indígena (Conadi), servicio público descentralizado que básicamente tiene a cargo la creación, promoción y coordinación de las políticas gubernamentales dirigidas a los pueblos indígenas; 2) el Fondo de Tierras y Aguas Indígenas, eje central de la política indígena de los gobiernos de la Concertación ${ }^{169}$, que ejecuta el programa de restitución de tierras y aguas a través de mecanismos tales como la compra directa de tierras, traspasos de tierras fiscales, subsidios para la ad-

169 Como explica la DIPRES, Informe Final de Evaluación Programa Fondo de Tierras y Aguas Indígenas. Corporación Nacional de Desarrollo Indígena, agosto 2008, p. 119, “[d]esde sus inicios, el Fondo de Tierras y Aguas Indígenas ocupó más del $50 \%$ de los recursos de dicha institución: desde esta perspectiva, es su programa más relevante", disponible en http://www.dipres.cl/574/article-38678.html (última visita 6 de marzo de 2010). Según datos de Libertad y Desarrollo, Temas Públicos $\mathrm{N}^{\circ} 939$, de 16 de octubre de 2009, el Fondo de Tierras y Aguas Indígenas habría recibido el 58\% del Presupuesto de la Conadi del año 2009 y el 64\% del presupuesto del año 2010. Por su parte, el Fondo de Desarrollo Indígena habría recibido en promedio sólo un 5\% del presupuesto de la Conadi durante el período 2004-2008. 
quisición de predios, financiamiento de regularización de títulos, etc. ${ }^{170}$; 3) el Registro Público de Tierras Indígenas, donde deben inscribirse las tierras indígenas; 4) el Fondo de Desarrollo Indigena, administrado por la Conadi, que está destinado a financiar programas especiales de desarrollo; y, 5) las Áreas de Desarrollo Indigena, definidas como "espacios territoriales en que los organismos de la administración del Estado focalizarán su acción en beneficio del desarrollo armónico de los indígenas y sus comunidades" (actualmente son nueve, más una en trámite) ${ }^{171}$.

Con posterioridad a la dictación de la Ley 19.253, los mayores hitos en materia de política indígena han sido la Comisión de Verdad Histórica y Nuevo Trato y el Programa Orígenes, ambos establecidos bajo la administración Lagos. La Comisión de Verdad Histórica y Nuevo Trato fue creada el 2001 y contó con la participación de equipos multidisciplinarios, integrados por amplios sectores políticos y sociales. En su informe final (2003), se presenta la historia de la relación entre los pueblos indígenas y el Estado, y se sugieren propuestas para una nueva política respecto de los pueblos indígenas.

Por su parte, el Programa Orígenes fue creado el 2001 y tiene por finalidad "[m]ejorar de manera sostenible las condiciones de vida de las comunidades de los pueblos Aymara, Atacameño y Mapuche, en el área rural, y promover su desarrollo con identidad, particularmente en los ámbitos económico, social, cultural, ambiental y jurídico" ${ }^{172}$. Se trata de un esfuerzo integral, intersectorial y participativo, financiado

${ }^{170}$ Véase Artículo 20 de la Ley 19.253 y Decreto (Mideplan) N 395 de 1993 , que Reglamenta el Fondo de Tierras y Aguas Indígenas. De acuerdo a la información de Conadi, se han entregado: 1) 27.240 hectáreas, correspondientes a MM\$ 41.077 (\$ de diciembre 2008) de conformidad al Artículo 20 letra a) (subsidios para la compra), y 2) $95.814,07$ hectáreas, correspondientes a MM\$ 126.814 ( $\$$ de diciembre de 2008) de conformidad al Artículo 20 letra b) (compra de tierras en conflicto), disponible en http:// www.conadi.cl/index.php?option $=$ com_content\&view $=$ article $\&$ id $=79 \&$ Itemid $=67$ (última visita 6 de marzo de 2010).

${ }^{171}$ El Fondo de Cultura y Educación no fue creado expresamente por la Ley 19.253, pero fue instituido por la Conadi en aplicación de su artículo 28. Su fin es incentivar, fortalecer, promover y difundir las culturas, idiomas y conocimientos indígenas a favor de la diversidad cultural.

172 Dirección General de Presupuesto, Sintesis Ejecutiva. Programa Orígenes, junio 2004, p. 2. Véase también, Dirección General de Presupuesto, Informe Final de Evaluación. Programa Orígenes. Ministerio de Planificación y Cooperación, junio 2004, p. 5. 
con préstamos del BID y contribuciones del Estado ${ }^{173}$, que actualmente se encuentra en su segunda fase de implementación ${ }^{174}$. Abarca distintas dimensiones de la vida de los pueblos indígenas, incluyendo planificación local y territorial, proyectos comunitarios, productivos, culturales y de medicina tradicional. Comprende asimismo a diversos sectores del Estado, en los cuales busca crear capacidades para que "la atención a las personas y comunidades indígenas sea articulada, adecuada y con pertinencia cultural"175.

Por su parte, el gobierno de Bachelet dio continuidad a una política centrada en la entrega de tierras, manteniendo el Fondo de Tierras y Aguas Indígenas como el programa más importante en materia indígena. La ratificación del Convenio 169 constituye el cambio normativo más significativo de la saliente administración, especialmente comparado con el intento tardío por crear un Ministerio de Asuntos Indígenas y Agencia de Desarrollo Indígena (en reemplazo de la Conadi) ${ }^{176}$ y el fallido "Código de Conducta Responsable para Inversiones en Tierras y Áreas de Desarrollo Indígena"177.

En definitiva, esta reseña muestra cómo la cuestión indígena es de larga data en nuestro país. La legislación, variada y contradictoria, se ha destacado históricamente por ser errática y variante. En los últimos diecisiete años, la política indígena ha estado basada en un fondo de adquisición de tierras y aguas, fondo que a su vez ha estado enfocado en la compra de terrenos con "conflicto jurídico". En retrospectiva, el di-

${ }^{173}$ El presupuesto total del Programa Orígenes, incluyendo sus dos fases, asciende a \$ 183.327 millones, de los cuales \$ 79.720 millones provienen del BID. Véase presentación powerpoint de Fernando Quilaleo Aguirre, Coordinador Nacional del Programa Orígenes, 7 de febrero de 2008, disponible en http://www.impactalliance.org/ ev_es.php?ID=45229_201\&ID2=DO_TOPIC (última visita 6 de marzo de 2010).

${ }^{174}$ El "ejecutor" de la primera fase del Programa (2001-2006) fue Mideplan. El Programa Orígenes depende hoy de la Conadi y consta de dos Subprogramas: "Desarrollo Integral de Comunidades Indígenas" - que incluye fortalecimiento de comunidades y organización indígena, identidad cultural y desarrollo económico de familias y comunidades - y "Oferta Pública" — que incluye adecuación de instrumentos y prácticas de los servicios públicos y apoyo a iniciativas de institucionalización y sostenibilidad del modelo de intervención del programa-.

175 Véase n. 169 (Informe Final...), p. 4. Como se explica ahí mismo, el Programa "intenta introducir la interculturalidad en las prácticas de las instituciones estatales, con las que conviven cotidianamente las comunidades y personas indígenas".

${ }^{176}$ Boletín $N^{\circ}$ 6726-06. El Mensaje fue enviado a la Cámara de Diputados el 29 de septiembre de 2009.

${ }^{177}$ El proyecto de Código fue entregado por Rodrigo Egaña, Comisionado Presidencial para Asuntos Indígenas, a la Presidenta Bachelet en abril de 2009. 
seño se aprecia como propicio para producir una escalada de conflictos étnico-territoriales ${ }^{178}$ : un subsidio creado sobre la base de "problemas relativos a tierras"179 o "tierras en conflicto" promueve los problemas y los conflictos jurídicos ${ }^{180}$. Si a ello agregamos los problemas — si bien no en un sentido estricto, pero sí en forma más o menos próxima- de activos específicos y hold-up ${ }^{181}$ que se derivan de un sistema de compraventas voluntarias ${ }^{182}$, el resultado es una política pública explosiva, especulativa y distributivamente desastrosa ${ }^{183}$. La implementación del Convenio 169 constituye una nueva oportunidad para abordar la cuestión indígena; esta vez debemos intentar más seriamente darle una solución digna, honesta y perseverante.

\section{EL DERECHO A LA PARTICIPACIÓN EN EL CONVENIO 169}

Como ya lo anticipamos, este trabajo aborda dos de los derechos más complejos y conflictivos del Convenio 169: participación, consulta y consentimiento previo, libre e informado - reconocido por los artículos 6 y 7-y recursos naturales — reconocido por el artículo 15-.

${ }^{178}$ Es muy factible que en el diseño de la Ley 19.253 se haya optado por la compra voluntaria y no por la expropiación dado el contexto en que el proyecto de ley fue enviado a tramitación al Congreso (1991): recién se había recuperado la democracia y aún estaban vigentes las aprensiones y resistencias a las expropiaciones, como consecuencia de las experiencias vividas durante la reforma agraria, especialmente bajo el gobierno de Salvador Allende.

${ }^{179}$ Véanse Artículo 20 letra c) de la Ley 19.253 y Decreto Supremo (Mideplan) No 395 de 1993, artículos 1 letra b) y 6.

${ }^{180}$ Se trata de un caso de riesgo moral o moral hazard.

181 En entrevista otorgada al diario La Nación, 21 de agosto de 2009, el presidente de la Sociedad de Fomento Agrícola de Temuco, Gastón Caminondo, declaró: "Hay muchos dueños de predios que se están viendo forzados a vender y obviamente si me obligan a salir de donde estoy, voy a pedir una cantidad de dinero por lo que yo tengo. Quien esté dispuesto a pagar, bien y si no, no", disponible en http://www.lanacion.cl/ prontus_noticias_v2/site/artic/20090821/pags/20090821004054.html (última visita, 21 de marzo de 2010).

${ }^{182}$ No se ha tomado conciencia del "desastre distributivo", a pesar que la DIPRES ha recomendado dos veces, en el 2001 y en el 2008, que se realice un estudio de mercado desagregado por regiones y por zonas. Pero es un hecho público y notorio que los precios que se han pagado por las tierras son muy altos. Así lo reconoce el propio diario de gobierno. Véase La Nación, 23 de agosto de 2009, "Precios de tierras en la Araucanía suben casi $300 \%$ este año", disponible en http://www.lanacion.cl/prontus_noticias_v2/site/artic/20090821/pags/20090821002057.html (última visita 20 de marzo de 2010).

183 Para los problemas de activos específicos y hold up, véanse los trabajos clásicos de Oliver E. Williamson, The Economic Institutions of Capitalism, 1985, y The Mechanisms of Governance, 1996. 
A continuación analizaremos las distintas modalidades del derecho a participación, sus características relevantes, y finalmente presentamos nuestras consideraciones relativas a su implementación en el Derecho chileno.

\section{IV.a. Las distintas modalidades del derecho a la participación en el} Convenio 169

El derecho a la participación constituye un derecho colectivo genérico que tiene por objeto asegurar la intervención de los pueblos indígenas en las medidas estatales que los afecten de manera directa. El mayor o menor grado de intervención depende de la modalidad concreta que adopte el derecho a la participación. Así, en una escala progresiva, de menos a más, nos encontramos con el derecho a la participación propiamente tal, el derecho a la consulta y, finalmente, el derecho al consentimiento previo, libre e informado.

El derecho a la participación propiamente tal consiste en la libre concurrencia de los pueblos indígenas en la formulación, aplicación y evaluación de planes, políticas y programas que los afecten directamente. El Convenio contempla este derecho en sus artículos 6.1.b y 7.1 segunda parte - participación en general—, artículo 22.2 - participación respecto a programas de formación—, 23.1 - participación respecto a actividades económicas tradicionales - y 27.2 —participación respecto a programas de educación-.

A su vez, el derecho a la consulta se traduce en la obligación de los Estados de solicitar la opinión de los pueblos indígenas en materia de planes, políticas y programas que los afecten directamente y se contempla en los artículos 6.1.a y 6.2 — consulta en general一, artículo 15.2 - consulta respecto de los recursos minerales-y artículo 17.2 - consulta respecto a la enajenación de tierras-

Finalmente, el derecho al consentimiento previo, libre e informado que, como su propio nombre lo sugiere, implica una expresión vinculante por parte de los pueblos indígenas, es recogido por el Convenio en su artículo 16.2 — consentimiento para el traslado y reubicación de los pueblos indígenas de sus tierras-. 
IV. b. Características del derecho a la participación en el Convenio 169

El derecho a la participación en su sentido genérico reconocido por el Convenio 169 -que incluye participación propiamente tal, consulta y consentimiento previo- presenta al menos diez características que ameritan una revisión detenida.

\section{Se trata de un principio inspirador del Convenio 169}

El derecho a la participación es un principio general que inspira el Convenio 169 y que es primordial para su interpretación y aplicación ${ }^{184}$. De hecho, el mismo Convenio, en su Capítulo Primero "Política General", artículo $2^{\circ}$, dispone que los gobiernos deben desarrollar, con la participación de los pueblos interesados, una acción coordinada y sistemática con miras a proteger los derechos de esos pueblos y a garantizar el respeto de su integridad.

2. Es un derecho autoejecutable y plenamente justiciable

Como señalamos en el capítulo II del presente trabajo, el Convenio 169 es un tratado de derechos humanos y, como tal, es autoejecutable conforme a lo dispuesto en el artículo $5^{\circ}$ de la Constitución ${ }^{185}$. De este modo, las normas sobre participación que consagra el Convenio forman parte del ordenamiento interno de nuestro país.

Además, los derechos a la participación, consulta y consentimiento previo, libre e informado no sólo son autoejecutables sino que, además, plenamente justiciables. Aunque los procedimientos de participación en su sentido genérico pueden y deben ser regulados en detalle mediante ley o reglamento, dichas normativas no son esenciales para la existencia de ese derecho. Es decir, el derecho a la participación no depende de la creación y establecimiento de una política pública por parte de los órganos políticos del Estado. La participación puede siempre ser estructurada directamente por los órganos públicos llamados a aplicar el Convenio 169 mediante procesos ad-hoc de participación.

De este modo, los tribunales nacionales tendrán competencia para pronunciarse sobre aquellas medidas que, afectando directamente a los

${ }^{184}$ Véase Guía Corta, n. 50, 14.

185 Véase supra la discusión detallada sobre la materia planteada en la sección II.e, nn. 133-142 y texto acompañante. 
pueblos indígenas, no han contado con su participación en sentido genérico en los términos del Convenio 169. Así, por ejemplo, los tribunales ordinarios podrán eventualmente decretar la nulidad de aquellas decisiones administrativas que no han contado con la participación indígena y el Tribunal Constitucional declarar la inconstitucionalidad o inaplicabilidad de una ley que no haya sido consultada a las comunidades interesadas.

3. Se aplica respecto de materias que afecten directamente a los pueblos indígenas

El derecho a la participación sólo se ejerce respecto de materias que afecten directamente a los pueblos indígenas ${ }^{186}$. Es lógico que así sea, porque de otro modo cualquier medida o decisión que pretenda adoptar el gobierno tendría que contar con la participación de los pueblos originarios.

El punto central es distinguir las materias que afecten directamente a los pueblos indígenas de las que lo hagan sólo indirectamente. Dado que no es posible encontrar un criterio general, debe emplearse, conservadoramente y de buena fe, un análisis casuístico que resguarde los derechos que se reconocen a los pueblos originarios. Conforme al espíritu del Convenio 169, deben ser los propios pueblos indígenas quienes asuman el control de sus instituciones, formas de vida y desarrollo económico, manteniendo y fortaleciendo sus identidades, lenguas y religiones.

Finalmente, al hablarse de pueblos indígenas interesados o afectados directamente, se hace alusión a la comunidad o las comunidades concretas sobre las cuales recaerá o aplicará el respectivo plan, programa, proyecto o política. Así, si se trata de un proyecto de inversión que se pretende desarrollar en el Alto Biobío, serán las comunidades allí ubicadas las que tendrán derecho a expresarse sobre el mismo y no todo el pueblo mapuche, aunque tales comunidades pertenezcan a dicho pueblo. Por el contrario, si se trata de una política de fomento de la enseñanza del mapudungun a nivel nacional, obviamente el derecho a la

${ }^{186}$ Así, por ejemplo, los artículo 6.1.a), 6.1b) y 7.2, señalan en forma expresa que debe tratarse de medidas que afecten "directamente" a los pueblos indígenas o que "les conciernan". En el caso de otros artículos — como el 17.2 o el 23.1- que si bien no utilizan vocablos como "directamente" u otros análogos, dicha idea se desprende de su texto al estar referidos a materias propias del interés de los pueblos indígenas, como sus tierras o sus actividades económicas. 
participación les asistiría a todas las comunidades mapuches a lo largo del país.

4. Debe verificarse respecto de medidas administrativas y legislativas, nacionales o regionales y en todos sus niveles

El derecho a la participación en sentido genérico se plantea respecto de medidas legislativas y administrativas. Así, el derecho a la participación aplica a los entes colegisladores y a la actividad de todos los órganos integrantes de la administración del Estado — centralizada y descentralizada, concentrada y desconcentrada-, incluidas las municipalidades y empresas del Estado.

De acuerdo al artículo 7.1, el derecho a la participación se exige para planes y programas de desarrollo tanto nacional como regional, debiendo entenderse este último vocablo no como referido a la región en su sentido estricto de división político-administrativa de nuestro país, sino como sinónimo de 'local' en contraposición de lo nacional. Por otra parte, conforme al artículo 6.1 letra a), este derecho debe verificarse en "todos los niveles", es decir, en todas las etapas o fases de una política pública, desde su concepción y diseño, pasando por su implementación, desarrollo y aplicación, como también por su evaluación ${ }^{187}$. De esta manera, el Convenio busca darle la mayor amplitud al derecho a la participación, evitando que quede acotado a fases específicas del desarrollo de las políticas públicas.

\section{No obliga directamente a los privados}

Como hemos visto en el punto anterior, el Convenio impone la obligación de participación respecto de medidas legislativas y administrativas. De este modo, obliga en forma directa únicamente a los entes públicos, entendiendo por tales a los órganos de la administración del Estado, en todos sus niveles, al Congreso Nacional y a las municipalidades.

No obstante lo anterior, los privados sí podrían verse afectados por las normas de participación que establece el Convenio, por vía indirecta, cuando se trate de medidas administrativas y legislativas que les sean aplicables a sus proyectos.

187 Organización Internacional del Trabajo, Convenio Número 169 sobre Pueblos Indígenas y Tribales: Un Manual, 2003, p. 19 [en adelante, OIT, Manual Convenio 169]. 
6. No se traduce en un derecho a veto, salvo tratándose del caso de consentimiento previo, libre e informado

El derecho a la participación en sentido genérico - con la excepción de la modalidad de consentimiento previo, libre e informado- no se traduce en un derecho a veto por parte de los pueblos indígenas. Ello se infiere del artículo 6.2 del Convenio 169, conforme al cual la consulta tiene "la finalidad de llegar a un acuerdo o lograr el consentimiento acerca de las medidas propuestas", pero sin imponer la obligación de alcanzar tal acuerdo o de obtener tal consentimiento ${ }^{188}$.

7. Debe realizarse de buena fe y por medio de procedimientos apropiados

El artículo 6.2 dispone que las consultas deben "efectuarse de buena fe y de una manera apropiada a las circunstancias, con la finalidad de llegar a un acuerdo o lograr el consentimiento acerca de las medidas propuestas". Lo anterior significa que, aunque la participación no implica un derecho a veto, debe necesariamente efectuarse de manera tal que no sea un mero trámite desprovisto de la seria intención de obtener la opinión informada de los pueblos indígenas.

Los gobiernos, al consultar a los indígenas, deben proporcionarles información apropiada y completa, que pueda ser plenamente comprendida. Asimismo, los órganos estatales no deben consultar a cualquiera que diga representar a las comunidades afectadas. Las consultas deben emprenderse con organizaciones e instituciones genuinamente representativas, que estén habilitadas para tomar decisiones o hablar en nombre de las comunidades interesadas ${ }^{189}$.

\section{Implica un poder de negociación}

La participación lleva implícito un poder de negociación para los pueblos indígenas. De acuerdo al Manual Convenio 169 elaborado por la OIT, el tratado "dispone el espacio necesario para que los pueblos indígenas y tribales puedan negociar para proteger sus derechos"190.

\footnotetext{
${ }^{188}$ Véase OIT, Guía Corta, n. 50, pp. 14-15.

189 Véase OIT, Guía Corta, n. 50, p. 15. Véase también OIT, Manual Convenio 169, n. 187, p. 22.

${ }^{190}$ OIT, Manual Convenio 169, p. 17.
} 
Este poder de negociación se infiere del mismo artículo 6.2 en cuanto señala que las consultas deben realizarse con la finalidad de llegar a un acuerdo o lograr el consentimiento. Sin la posibilidad de negociación, a los indígenas no les quedaría más alternativa que aprobar o rechazar (aunque no vetar) la respectiva medida en bloque, sin poder discutir en forma pormenorizada su contenido, lo que es incompatible con el espíritu del Convenio 169.

9. La forma concreta que adopte la participación queda entregada a cada Estado

La forma o procedimiento concreto que adopte la participación en sentido genérico depende de cada Estado. De hecho, es el propio Preámbulo del Convenio 169 el que señala que las aspiraciones de los pueblos indígenas deben desarrollarse "dentro del marco de los estados en que viven"191. Los artículos 33 y 34 del mismo texto así lo ratifican: conforme al primero, los Estados contratantes tienen la obligación de establecer las instituciones y mecanismos para administrar los programas que dispone el Convenio; conforme al segundo, que establece el "principio de flexibilidad", todas las medidas que se adopten conforme al Convenio deben tener en cuenta las condiciones propias de cada país.

10. Innova respecto al derecho a la participación contemplado en la Ley Indígena

El derecho a la participación del Convenio 169 es más favorable a los pueblos indígenas que el derecho equivalente previamente reconocido por nuestro sistema legal. En efecto, el Párrafo I del Título V de la Ley Indígena 19.253 de 1993 se refiere al derecho a la participación indígena. En su artículo 34 establece el derecho a la consulta en los siguientes términos:

Los servicios de la administración del Estado y las organizaciones de carácter territorial, cuando traten materias que tengan injerencia o relación con cuestiones indígenas, deberán escuchar

${ }^{191}$ El Preámbulo señala que el Convenio se adopta "Reconociendo las aspiraciones de esos pueblos a asumir el control de sus propias instituciones y formas de vida y de su desarrollo económico y a mantener y fortalecer sus identidades, lenguas y religiones, dentro del marco de los Estados en que viven". 
y considerar la opinión de las organizaciones indígenas que reconoce esta ley. Sin perjuicio de lo anterior, en aquellas regiones y comunas de alta densidad de población indígena, éstos a través de sus organizaciones y cuando así lo permita la legislación vigente, deberán estar representados en las instancias de participación que se reconozca a otros grupos intermedios ${ }^{192}$.

El contraste de las normas de participación de la Ley 19.253 con las del Convenio 169 lleva a la conclusión de que estas últimas implican una innovación en al menos tres dimensiones relevantes. En primer lugar, el Convenio 169 establece la consulta como un trámite necesario no sólo para los "servicios de la administración del Estado" sino además para el Congreso Nacional y todo otro órgano estatal. En segundo lugar, el Convenio exige el consentimiento previo, libre e informado tratándose del traslado y reubicación de los pueblos indígenas de sus tierras. En tercer lugar, el Convenio otorga al derecho a la participación una fuerza y connotación jurídica especial; como ya hemos visto, la participación del Convenio debe hacerse de buena fe, por los procedimientos apropiados y, sobre todo, buscando llegar a un acuerdo con los pueblos indígenas o lograr su consentimiento ${ }^{193}$.

\section{IV.c. Implementación del derecho a participación establecido en el Convenio 169 en el Derecho chileno}

Dado que el Convenio 169 es autoejecutable y justiciable en materia de participación, entonces todo cuanto hemos explicado en el acápite precedente es ley de la República. En vista además que nuestra

192 Por su parte, el artículo 35 de la misma ley se refiere a la participación que deben tener las comunidades indígenas en la administración de las áreas silvestres protegidas ubicadas en áreas de desarrollo indígena (ADIS), entregando la determinación de dicha participación a la CONAF, al SAG y a la Conadi, actuando de común acuerdo y caso a caso.

${ }^{193}$ Así lo constató el Tribunal Constitucional, Sentencia Rol 309, n. 82, considerando 7: "La argumentación del Presidente de la República en orden a que este tipo de consultas ya se encuentra establecido en nuestra legislación, citando en abono de sus tesis los artículos 34, 39, letra j), y 48, de la Ley Indígena, no es compartida por este Tribunal, habida consideración de la diferencia esencial que tiene la consulta a que se refiere el artículo $6^{\circ}, N^{\circ} 1^{\circ}$, letra a), de la Convención $N^{\circ} 169$, con aquellas otras que se establecen en el actual ordenamiento positivo. Para demostrarlo baste señalar que si bien la respuesta a la consulta a que se refiere el tratado no tiene un carácter vinculante stricto sensu si (sic) tiene una connotación jurídica especial que se encarga de precisarla el $N^{\circ}$ $2^{\circ}$ del mismo artículo $6^{\circ}$...". (énfasis agregado). 
Ley $\mathrm{N}^{\circ} 19.253$ no pasa los estándares del Convenio 169 —al menos parcialmente-, debe concluirse que es el propio Convenio el que rige en calidad de lex posteriori. Más aún, en cuanto tratado de derechos humanos, el Convenio 169 es inderogable y no-inaplicable tanto por el legislador como por los tribunales (salvo el Tribunal Constitucional en sede de inaplicabilidad por inconstitucionalidad).

Por ende, los órganos del Estado deben cumplir con los estándares de participación, consulta y consentimiento previo e informado definidos por el Convenio 169. A este respecto, cabe hacer notar que mientras no se dicten las normas reglamentarias que precisen y detallen apropiada y autoritativamente los procedimientos exigidos por el Convenio 169, se corre el riesgo de viciar de nulidad e inconstitucionalidad los actos estatales que incidan directamente sobre los pueblos indígenas. En ausencia de tales normas generales de procedimiento, las autoridades administrativas deberán tener especial cuidado en cumplir caso a caso con los estándares establecidos en los artículo 6 y 7 del Convenio 169.

A nivel legislativo, el derecho a la participación debe observarse en el proceso de tramitación de las leyes, cuya reglamentación, de acuerdo al artículo 55 de la Constitución, se encuentra entregada a la Ley Orgánica Constitucional del Congreso Nacional. De este modo, en la discusión de los proyectos de ley que afecten directamente a los pueblos indígenas se deberá prever una instancia de participación para los mismos, instancia que, según lo dicho, podrá tener lugar y contar con las características y procedimientos que el mismo Congreso considere adecuados para el cumplimiento del Convenio $169^{194}$.

A nivel administrativo, cabe referirse obligadamente al artículo 34 de la Ley Indígena ${ }^{195}$ y su nuevo Reglamento de Consulta y Participación. Como señalamos más arriba y como el propio Tribunal Constitucional lo reconociera, el Convenio 169 innovó en materia de derecho a participación, con lo cual el artículo 34 debe entenderse tácitamente

${ }^{194}$ Discrepamos de la opinión del Tribunal Constitucional sostenida en la Sentencia Rol 309, n. 82, y Sentencia Rol 1050, n. 134, en cuanto a que el artículo 6.1.a del Convenio 169 sería modificatorio del artículo 22 de la Ley Orgánica Constitucional del Congreso Nacional, referido a la facultad de las comisiones para reunir antecedentes, solicitar informes y oír a las personas e instituciones que estime conveniente. El Convenio 169 no obliga a las comisiones a dar participación a los pueblos indígenas, sino al Congreso. Por ello, bien puede el Congreso dar lugar a la participación de una manera distinta a la prevista en el citado artículo 22. En el mismo sentido, Correa, "Informe de Constitucionalidad", n. 129.

${ }^{195}$ Véase sección IV.b. número 10. 
derogado (al menos en su primera parte). De este modo, el nuevo reglamento, que intenta ejecutar una norma legal parcialmente derogada, corre el serio riesgo de ser nulo de nulidad de Derecho público. Debe notarse que se tomó razón del referido reglamento el 22 de septiembre de 2009 cuando el Convenio 169 ya estaba vigente. Más aún, como el mismo reglamento reconoce en sus considerandos y en su artículo transitorio, el mismo no fue sometido a consulta, por lo que su validez es más que discutible.

Más allá de su invalidez formal un tanto vergonzosa, creemos que el Reglamento de Consulta y Participación comete todos los errores que debían evitarse. En vez de crear un procedimiento que tratara a los pueblos indígenas con la dignidad que corresponde y que se constituyera en un benchmark nacional en materia de participación ciudadana, el citado Reglamento aparece como un absurdo intento de última hora por burlar el derecho de participación de los pueblos indígenas. El hecho que además se hayan excluido de su aplicación las empresas del Estado y las municipalidades termina por desafiar la lógica y las intenciones detrás de su promulgación. No es sorprendente, entonces, que algunas de las ONG del ramo hayan reaccionado virulentamente contra este reglamento ${ }^{196}$.

Chile debe tomar en serio los compromisos internacionales que voluntariamente asumió en materia indígena. Es hora de enmendar el rumbo y hacer cumplir los artículos 6 y 7 del Convenio 169 que son leyes de la República. Es tiempo de cambiar la lógica burocrática y secretista del Derecho administrativo chileno en lo que respecta a los reglamentos, y reemplazarla por una lógica democrática y participativa. No debemos temer a establecer procedimientos abiertos que permitan a la autoridad tomar contacto directo con los afectados e interesados.

\section{EL DERECHO SOBRE LOS RECURSOS NATURALES EN EL CONVENIO 169}

El segundo grupo de derechos consagrados en el Convenio 169 que revisaremos en este trabajo son los que el artículo 15 reconoce respecto a los recursos naturales ${ }^{197}$. Estos derechos de los pueblos

196 Véase, por ejemplo, http://www.politicaspublicas.net/panel/imp/392decreto-124.html. Para una postura más moderada, véase Matías Meza-Lopehandía, El Reglamento sobre Consulta a Pueblos Indígenas Propuesto por el Gobierno de Chile, la Buena Fe y el Derecho Internacional de los Derechos Humanos, 2010.

${ }^{197}$ Ver artículo 15 citado en p. 8. 
indígenas constituyen una de las dimensiones más controvertidas de este tratado, sobre todo por constituir una fuente de incertidumbre para aquellos proyectos de inversión a desarrollarse en tierras indígenas ${ }^{198}$. Una inadecuada implementación del tratado a este respecto puede conllevar una enorme pérdida de oportunidades de crecimiento económico para el país y especialmente para los propios pueblos indígenas. Revisaremos a continuación el concepto de "tierras", los derechos indígenas sobre sus propios recursos naturales y los derechos que se les reconocen en relación con los recursos naturales estatales que se ubiquen en sus territorios.

\section{V.a. El concepto de "tierras" para efectos de la aplicación del artículo 15}

El artículo 15 consagra derechos en favor de los pueblos indígenas sobre los recursos naturales "existentes en sus/las tierras". Como cuestión preliminar es entonces crucial determinar el significado que para el Convenio tiene la voz "tierras".

El Derecho internacional indígena, como hemos explicado, tiene como uno de sus objetivos principales proteger la identidad cultural y las formas de vida de los pueblos indígenas, particularmente los componentes espaciales y políticos de dicha identidad y formas de vida ${ }^{199}$. El Convenio 169 exige así a los gobiernos "respetar la importancia especial que para las culturas y valores espirituales de los pueblos interesados reviste su relación con las tierras o territorios" (artículo 13.1). Les exige también reconocer a los pueblos indígenas "el derecho de propiedad y de posesión sobre las tierras que tradicionalmente ocupan", incluyendo las tierras no exclusivamente ocupadas a las que "hayan tenido tradicionalmente acceso para sus actividades tradicionales y de subsistencia" (artículo 14.1).

198 Véase OIT, Guía Corta, n. 50, p. 24 (reconociendo que "[é]sta [en referencia al artículo 15] es una disposición muy delicada").

${ }^{199}$ Véase n. 177 y texto acompañante. Como lo ha señalado la Corte Interamericana de Derechos Humanos, "La cultura de los miembros de las comunidades indígenas corresponde a una forma de vida particular de ser, ver y actuar en el mundo, constituido a partir de su estrecha relación con sus tierras tradicionales y recursos naturales, no sólo por ser estos su principal medio de subsistencia, sino además porque constituyen un elemento integrante de su cosmovisión, religiosidad y, por ende, de su identidad cultural" (Sawhoyamaxa, n. 24, considerando 118). 
Respecto al alcance del término "tierras" de los artículos 15 y 16, el artículo 13.2 del Convenio señala que este término "deberá incluir el concepto de territorios", lo que "cubre la totalidad del hábitat de las regiones que los pueblos interesados ocupan o utilizan de alguna otra manera". Esta definición proviene del Convenio 107 de la OIT $^{200}$, predecesor directo del Convenio 169, y su importación a este tratado fue objeto de prolongadas negociaciones. La solución finalmente adoptada se caracteriza por su amplitud para ser aplicada a las diferentes situaciones en las que se encuentran los pueblos indígenas, incluyendo tanto pueblos sedentarios como nómades (la situación es obviamente más compleja respecto de estos últimos). Esto se ve confirmado por el principio de flexibilidad que se reconoce en el artículo 34 del Convenio ${ }^{201}$, que exige tomar en cuenta la realidad y condiciones propias de cada país y de cada pueblo indígena ${ }^{202}$.

En definitiva, el Convenio 169 reconoce tres niveles de derechos sobre las tierras, que nosotros "etiquetamos" aquí en los siguientes términos: a) "Propiedad tradicional": derecho exclusivo y excluyente sobre las tierras tradicionalmente ocupadas por los pueblos indígenas ${ }^{203}$; b) "Servidumbre tradicional": derecho de uso no exclusivo ni excluyente sobre tierras a las que tradicionalmente los pueblos han tenido acceso para sus actividades tradicionales y de subsistencia (esta "servidumbre tradicional" es especialmente relevante tratándose de pueblos indígenas que se han dedicado al pastoreo, caza y recolección $\left.{ }^{204}\right)$; y, c) "Derecho

200 Convenio 107 de la OIT Relativo a la Protección e Integración de las Poblaciones Indigenas y de Otras Poblaciones Tribales y Semitribales en los Países Independientes, 1957.

${ }^{201}$ Artículo 34 del Convenio 169: "La naturaleza y el alcance de las medidas que se adopten para dar efecto al presente Convenio deberán determinarse con flexibilidad, teniendo en cuenta las condiciones propias de cada país".

202 OIT, Guía Corta, n. 50, p. 21.

203 Según se explica en OIT, Manual Convenio 169, n. 187, p. 31, la Corte Suprema de Australia ha declarado que la ocupación o posesión tradicional de la tierra por parte de los indígenas constituye un título válido para el common law australiano, siempre que los pueblos aborígenes hayan mantenido su conexión con la tierra durante los años del asentamiento europeo y que dichos títulos no hayan sido extinguidos por disposiciones legítimas de los gobiernos imperial, estatal, territorial o del commonwealth.

${ }^{204}$ El Artículo 14.1 parte final indica que "[a] este respecto, deberá prestarse particular atención a la situación de los pueblos nómadas y de los agricultores itinerantes". La frase "en los casos apropiados" de la oración anterior de este artículo debe leerse también en el contexto del artículo 23 que establece el reconocimiento y fortalecimiento de las actividades tradicionales, inclusive la caza y el pastoreo. 
al hábitat": un derecho de contenido difuso sobre "el hábitat de las regiones que ocupan o utilizan de alguna otra manera", cuyo contenido depende de los artículos 15 (recursos naturales) y 16 (derecho al notraslado). Además, los pueblos indígenas gozan de un derecho a que el Estado les asigne tierras cuando las que dispongan "sean insuficientes para garantizarles los elementos de una existencia normal o para hacer frente a su posible crecimiento numérico" 205.

\section{V.b. El derecho de los indígenas a utilizar, administrar y conservar los recursos naturales existentes en sus tierras (artículo 15.1)}

La clave de interpretación del artículo 15 radica, como hemos visto, en que el Derecho internacional protege la identidad cultural y las formas de vida de los pueblos indígenas. Dada la relevancia que los recursos naturales tienen en la identidad y forma de vida de dichos pueblos, el Derecho los reconoce como una dimensión esencial de los intereses a los que se otorga protección. Esta observación constituye un punto clave tanto para no restringir los derechos de los pueblos indígenas como para no ampliarlos más allá de lo debido.

En materia de recursos naturales no estatales, el artículo 15.1 contempla la "protección" de los "derechos" sobre los recursos naturales existentes en tierras indígenas, incluyendo la "utilización, administración y conservación" de los mismos. Una interpretación razonable de este artículo exige distinguir el "nivel" de derechos sobre la tierra — "propiedad tradicional", "servidumbre tradicional" o "derecho al hábitat" - y el tercero a quien se opone el derecho —Estado o privadosConforme a esta distinción se puede plantear la Tabla titulada Derechos indígenas y recursos naturales, que aparece en la página siguiente.

El Convenio 169 no entrega más contenido o detalle que lo que brevemente se indica en esta matriz, por los que consideramos que se trata de una interpretación razonable a la luz del artículo 31 de la Convención de Viena sobre el Derecho de los Tratados. Como se sostiene en la Guía para la Aplicación del Convenio $N^{\circ} 169$, los países mantienen la libertad de implementar el artículo 15.1 conforme a los principios y conceptos propios de cada sistema legal doméstico, especialmente en el

${ }^{205}$ Artículo 19.a) del Convenio 169. La letra b) establece el derecho a "el otorgamiento de los medios necesarios para el desarrollo de las tierras que dichos pueblos ya poseen". 
TABLA: DERECHOS INDÍGENAS Y RECURSOS NATURALES

\author{
Frente al Estado \\ (Estado como autoridad)
}

Frente a los particulares

(Incluyendo Estado como propietario privado)

\begin{abstract}
Propiedad tradicional

- Utilización, administración y conservación limitada: Derecho a la propiedad, especialmente frente a regulaciones estatales que puedan poner en riesgo la identidad cultural y forma de vida. Deber de respetar regulaciones estatales razonables sobre la propiedad.
\end{abstract}

Servidumbre • Utilización, administración y consertradicional vación limitada: Derecho al contenido de la servidumbre, especialmente frente a regulaciones estatales que puedan poner en riesgo la identidad cultural y forma de vida. Deber de respetar regulaciones estatales sobre la propiedad subyacente y sobre la servidumbre misma.

Derecho al hábitat
- Conservación: Derecho a exigir que el Estado regule el uso de la propiedad vecina de manera que se conserven los recursos naturales propios y propiedad o servidumbre tradicional de los indígenas y no se ponga así en riesgo la identidad cultural y formas de vida indígena.
- Utilización, administración y conservación ilimitada: Derecho a la no interferencia, de carácter cuasi-absoluto (como en el caso del derecho de propiedad clásico).

- Utilización, administración y conservación limitada: Derecho a la no interferencia, de carácter relativo, conforme al contorno de la servidumbre tradicional.

- Conservación: Derecho a exigir que la utilización de las tierras vecinas no afecte la conservación de los recursos naturales propios y propiedad o servidumbre tradicional de los indígenas y no ponga en riesgo la identidad cultural y formas de vida indígena. No incluye el derecho a utilizar ni administrar recursos naturales que se encuentren en propiedades vecinas.

contexto de los derechos sobre las tierras que estos pueblos tienen y de su capacidad para ejercerlos ${ }^{206}$.

En cualquier caso, la situación de los derechos a los recursos naturales indígenas no parece muy distinta que la de los mismos derechos no-indígenas, al menos en cuanto a su contenido legal (sin perjuicio de lo que se dirá más adelante respecto al "derecho al hábitat"). La

${ }^{206}$ De acuerdo a la OIT, Guía Corta, n. 50, p. 24, esta disposición “está redactada en términos no muy precisos porque debe adaptarse a las diversas situaciones nacionales... Está claro que existe el derecho [a los recursos naturales]. Pero específicamente en qué consiste este derecho deberá definirse en el marco de cada ordenamiento jurídico nacional, en el marco de los derechos sobre las tierras que estos pueblos tienen y en el marco de su capacidad para ejercer estos derechos". 
misma tabla podría usarse para describir la relación de un propietario no-indígena sobre sus recursos naturales conforme al Código Civil. De modo que la diferencia más relevante en lo que respecta al artículo 15.1 parece encontrarse a nivel de monitoreo y enforcement de la ley ${ }^{207}$. El Estado tiene el deber especial de dar protección a los indígenas en la utilización, administración y conservación de sus recursos naturales, no siendo suficiente la simple garantía del acceso a los tribunales como lo es respecto de los propietarios no-indígenas (quienes se "defienden solos").

\section{V.c. Los derechos de los pueblos indígenas y los recursos naturales} estatales que se encuentren en sus tierras (art. 15.2)

El artículo 15.2 regula los derechos de los pueblos indígenas en relación con los recursos naturales estatales existentes en tierras indígenas. Dentro de estos recursos se encuentran las minas e hidrocarbu$\operatorname{ros}^{208}$, las aguas de la generalidad de ríos y lagos, los recursos pesqueros — que, aunque res nullius, están bajo tutela estatal—, entre otros. La disposición en comento trata los siguientes tres derechos: consulta, indemnización de perjuicios y participación en los beneficios.

La primera parte del artículo 15.2 se refiere al derecho a la consulta que tienen los pueblos originarios ${ }^{209}$. Tratándose de una manifestación del derecho más general a la consulta, nos remitimos a lo ya expresado en la sección cuarta de este trabajo. Sólo cabe agregar aquí dos cosas: primero, el derecho a la consulta resulta igualmente aplicable ya sea que se trate de una "propiedad tradicional", "servidumbre tradicional" o "derecho al hábitat"; segundo, si bien la consulta no otorga derecho a veto, el artículo 16 del Convenio 169 impide el traslado o desplazamiento de los pueblos indígenas sin su consentimiento previo, libre e informado.

La segunda parte del artículo 15.2 dispone que los pueblos indígenas tienen el derecho a "percibir una indemnización equitativa por

${ }^{207}$ Esta diferencia podría fundarse en el uso de la palabra "especialmente" en el artículo 15.1 del Convenio 169.

${ }^{208}$ En Chile, el artículo $19 \mathrm{~N}^{\circ} 24$ inc. $6^{\circ}$ de la Constitución dispone que "[e]1 Estado tiene el dominio absoluto, exclusivo, inalienable e imprescriptible de todas las minas".

209 Véase p. 8. 
cualquier daño que puedan sufrir como resultado de esas actividades [de terceros sobre los recursos naturales estatales]". Se trata entonces de una norma que exige que cualquier prospección o explotación de recursos naturales estatales que se autorice en tierras indígenas deba ir acompañada del pago de todos los daños y perjuicios causados a los pueblos originarios.

En este punto existen diferencias importantes entre los distintos niveles de derechos sobre las tierras. Tratándose de la "propiedad tradicional" o "servidumbre tradicional", el vínculo de causalidad entre la prospección o explotación y el daño causado será fácilmente demostrable. Por ejemplo, una explotación minera causará un daño superficial relativamente evidente sobre los propietarios superficiales ${ }^{210}$. Pero, en el caso del "derecho al hábitat", el vínculo causal será difícil aunque no imposible de acreditar. Así, una faena minera realizada en terrenos vecinos podría llegar a producir contaminación acústica o sobre las aguas que también cause perjuicios en tierras indígenas.

Finalmente, la segunda parte del artículo 15.2 establece que "[1]os pueblos interesados deberán participar siempre que sea posible en los beneficios que reporten tales actividades [relativas a recursos naturales estatales]". Según ya afirmamos, la frase "siempre que sea posible" implica que no estamos ni frente a un derecho humano ni tampoco frente a un derecho subjetivo público ${ }^{211}$. En otras palabras - y según lo reconoce la propia OIT-, los gobiernos mantienen la libertad de decidir si los pueblos indígenas se benefician o no de la explotación de los recursos naturales estatales que se encuentren en sus tierras ${ }^{212}$.

\section{V.d. Implementación del artículo 15}

Independientemente de la autoaplicabilidad del artículo 15 del Convenio 169, la pregunta crucial de esta sección se refiere a si nuestra Ley $\mathrm{N}^{\circ} 19.253$ y las demás normas de nuestro sistema relativas a propiedad sobre bienes raíces y recursos naturales constituyen una implementación suficiente del Convenio 169.

${ }^{210}$ No debe olvidarse que en Chile, conforme al artículo 122 del Código de Minería, "[1]as servidumbres se constituirán previa determinación del monto de la indemnización por todo perjuicio que se cause al dueño de los terrenos o al de la concesión sirviente, en su caso, o a cualquiera otra persona".

${ }^{211}$ Véase supra nn. 127 y 128 y texto acompañante.

212 OIT, Guía Corta, n. 50, p. 25. 
Los mínimos del Convenio 169 sobre este punto deben dividirse en dos grupos: las exigencias de Derecho público/justicia distributiva de creación de títulos ${ }^{213}$ y las exigencias de Derecho privado/justicia correctiva de creación de un estatuto que dé protección a la propiedad indígena (esto es, a los títulos existentes).

En cuanto a las exigencias de Derecho público, aunque no nos hemos referido en detalle a nuestra legislación de tierras indígenas por escapar al ámbito de este trabajo, la reivindicación de territorios indígenas constituye un presupuesto básico del derecho a los recursos naturales. Considerando el principio de flexibilidad contemplado en el artículo 34 del Convenio 169, nos parece que en general nuestra Ley $\mathrm{N}^{\circ} 19.253$ - en especial sus artículos 12 y 19 - supera los estándares mínimos del Convenio.

Ahora bien, como hemos señalado, la forma en que se encuentra diseñada dicha ley ha generado un gran número de conflictos étnicojurídicos. Por ello, la puesta en marcha del Convenio 169 es una invitación a modificar el esquema de reivindicación de tierras utilizado en estas últimas dos décadas, que ha dado lugar a conflictos y enriquecimiento injusto. La "propiedad tradicional" indígena, cuando resulte procedente reivindicarla, debe adquirirse vía expropiación y no por compraventa voluntaria ${ }^{214}$. Por su parte, la referencia directa o indirecta a tierras con conflicto debiera eliminarse de nuestra política pública.

Enseguida consideramos que el derecho a los beneficios establecido en el artículo 15.2 del Convenio 169 no debe implementarse en nuestro país. No se trata de un derecho humano ni tampoco de un derecho subjetivo, sino de una mera disposición odiosa que establece un spot-redistribution: quitar a A para dar a B. Como explica Tribe, la cláusula de expropiación previo pago de indemnización y conforme a fines públicos ha tenido tradicionalmente por finalidad evitar la redistribución directa (incluyendo los spot-redistributions ${ }^{215}$ ).

En nuestra opinión, no se trata de negar la redistribución en favor de los pueblos indígenas (todo lo contrario, como hemos argumentado en estas páginas), sino que dicha redistribución se haga con cargo al erario nacional, vale decir, financiada por todos los chilenos. Como últi-

${ }^{213}$ La reivindicación de tierras sobre fundamentos políticos y morales (y no jurídicos) la consideramos como una forma de creación de títulos y no como una reivindicación en sentido estricto. Pertenece por ello al universo del Derecho público y de la justicia redistributiva.

${ }^{214}$ Véase supra n. 183.

215 Tribe, n. 128, pp. 166-167. 
mo recurso, de existir voluntad política para establecer un derecho a los beneficios, debe romperse la negociación bilateral y recurrirse a un sistema de fondos o a un impuesto de recaudación definido objetivamente y a priori $^{216}$.

En cuanto a los mínimos de Derecho privado/justicia correctiva, consideramos que, de acuerdo a lo ya dicho, los conceptos de propiedad clásica y servidumbres regidos por el Código Civil cumplen con los mínimos del Convenio 169, sin perjuicio de que puedan hacerse esfuerzos adicionales por crear un estatuto más apropiado a la realidad de los pueblos indígenas. Ahora bien, el "derecho al hábitat" sí requiere de mayor implementación, por cuanto nuestras normas generales de protección de la propiedad frente a externalidades negativas y relaciones de vecindad son incompletas $^{217}$. El derecho sobre los recursos naturales, tanto sobre los recursos propios como sobre los estatales, sigue en esto la misma regla.

En todo caso, desde una perspectiva de políticas públicas, resulta crucial definir el alcance y extensión de los derechos indígenas sobre la propiedad y los recursos naturales con todo detalle, incluso yendo más allá de las definiciones que otorga el Derecho privado, pues como se desprende del teorema de Coase, pocas cosas hay peores que los derechos de propiedad mal o incompletamente definidos. Esto exige determinar la conveniencia de al menos tres cosas. Primero, definir los remedios ${ }^{218}$ que se otorgarán a la propiedad indígena, en especial si éstos se reducen a la indemnización de daños y perjuicios o también si se incluyen obligaciones de hacer y prohibiciones ${ }^{219}$. Segundo, tratándose del desarrollo de

${ }^{216}$ Un ejercicio interesante a este respecto puede encontrarse en el Mensaje de S.E. la Presidenta de la República con el que inicia un proyecto de ley que establece el pago de un impuesto específico de beneficio municipal por la instalación de una central generadora de energía eléctrica (Mensaje $\mathrm{N}^{\circ} 1650-357$ de 4 de noviembre de 2009, Boletín $\left.\mathrm{N}^{\circ} 6823-08\right)$.

217 A este respecto, el common law tiene un desarrollo más sofisticado de las externalidades negativas y las relaciones de vecindad. Existe una regulación especial de Derecho privado que se articula bajo los conceptos de public y private nuisance.

218 Seguimos acá un término del common law. En el mundo anglosajón, comprobada la infracción al Derecho, el juez tiene un importante ámbito de libertad para establecer cuál es el remedy o relief más apropiado, incluyendo la indemnización de perjuicios, la mera declaración y los casos más estrictos de restitución, injunctions y specific performance (cumplimiento forzado), entre otros.

${ }^{219}$ Esto es, en nomenclatura de Calabresi y Melamed, cuándo opera como regla de responsabilidad y cuándo como regla de propiedad. Véase Guido Calabresi y Douglas Melamed, "Property Rules, Liability Rules, and Inalienability: One View of the Cathedral", 1972. Existen otros remedios posibles, como puts y calls. Véase Ian Ayres, Optional Law. The Structure of Legal Entitlements, 2005. 
nuevas actividades en tierras vecinas, establecer la protección del derecho al hábitat de los pueblos indígenas por la vía administrativa y como condición previa al desarrollo de tales actividades. Y, tercero, determinar la situación de los usos vecinos actualmente en curso y si los mismos serán afectados o no por la nueva legislación indígena.

En definitiva, uno de los grandes desafíos de una buena política pública indígena es articular dos objetivos a veces contrapuestos: proteger los derechos de los pueblos originarios y promover su desarrollo económico incluyendo el de su entorno. Una política mal diseñada o mal implementada puede fácilmente transformarse en un factor de retroceso más que de avance; de eso no cabe duda. Pero, como dice el refrán, "el diablo está en los detalles". Una protección intensa y apropiadamente definida de la propiedad sobre la tierra y de los derechos sobre los recursos naturales propios y estatales no es incompatible con el desarrollo económico y social de los pueblos indígenas.

\section{Conclusiones}

En este artículo hemos intentado presentar una visión panorámica del Convenio 169. Hemos revisado el Derecho internacional de los derechos humanos, el Derecho internacional como gobernanza global, la historia del Derecho indígena chileno y su estado actual, para finalmente adentrarnos en los problemas específicos relativos a la implementación del Convenio 169 en materia de derecho a participación y recursos naturales.

La revisión de nuestro Derecho nos deja con una sensación de insatisfacción. La historia de desaciertos institucionales característica de nuestro pasado parece mantenerse inalterada en el presente. Uno de los momentos cúlmines de esta historia ocurrió en septiembre de 2009, cuando, en vez de decidirse por desarrollar una sólida política pública nacional en materia de participación, el gobierno aprobó el Convenio 169 para incumplirlo inmediatamente después en su aplicación interna con el Reglamento de Consulta y Participación.

No sería raro además que, autoconfundidos por el propio fraude que hemos hecho al Convenio 169 en materia de participación, terminemos por esforzarnos en implementar lo que no debe tomarse del Convenio: la participación en los beneficios de la explotación de recursos naturales estatales por parte de terceros, que, como hemos repetido va- 
rias veces, no es un derecho humano, no es un derecho subjetivo y sí es, en cambio, una pésima política pública. Cuando las cosas se hacen mal, es frecuente que se hagan mal para lado y lado: se frustra lo que debía hacerse apropiadamente y se implementa lo que no debe tocarse.

Al final del día, todo parece indicar que mientras no tomemos conciencia de la importancia, fundamento y justificación de los derechos indígenas, no podremos cambiar el rumbo de los acontecimientos. En este sentido, el esfuerzo de este trabajo ha sido precisamente ése: ayudar a tomar conciencia de qué es realmente lo que está en juego en materia de derechos indígenas ahora que nos corresponde implementar el Convenio 169, incluyendo, como dice Sierra, todos los "peligros y oportunidades" 220 . Tratamos, en definitiva, de ser parte de ese proceso dialéctico que Reisman describe en los siguientes términos:

Los derechos de los indígenas están siendo tardíamente reconocidos a favor del proceso dialéctico que trae los derechos humanos a la conciencia popular como la apremiante situación de individuos y grupos que han sido empujados a los márgenes del sistema legal y privados de los derechos básicos de la dignidad humana ${ }^{221}$.

Es de esperar que el presente gobierno y los que le sigan adopten una posición de mayor liderazgo que la que hemos visto en el pasado. Un Chile más grande, justo, inclusivo y pacífico así lo demanda. No debemos ni podemos olvidar que la obligación de establecer una política redistributiva en favor de las zonas más pobres del país — donde las poblaciones indígenas se destacan, particularmente el pueblo mapuche - tiene rango constitucional, incluso a nivel de "Bases de la Institucionalidad" 222 .

${ }^{220}$ Véase Lucas Sierra, El Mercurio, 31 de mayo de 2005 (“Chile enfrenta hoy el desafío de una correcta política indígena. En poco tiempo entrará en vigencia el Convenio 169 de la OIT. Este instrumento internacional obliga al Estado chileno a incorporar en sus políticas una serie de consideraciones relativas a sus ciudadanos indígenas. No le impone obligaciones específicas, pero sí una serie de criterios más o menos generales. Aquí está el peligro y la oportunidad. El peligro de que, al materializar esos criterios, surja el constructivismo social, el activismo y la utopía. Y la oportunidad, en cambio, que surja la sensatez, la racionalidad consciente de los límites de toda política pública y de los principios de la democracia liberal").

${ }^{221}$ Reisman, n. 12, p. 353 (traducción de los autores).

${ }^{222}$ Artículo $3^{\circ}$ inc. 3 de la Constitución: "Los órganos del Estado promoverán el fortalecimiento de la regionalización del país y el desarrollo equitativo y solidario entre las regiones, provincias y comunas del territorio nacional". 


\section{REFERENCIAS}

Alvarez, José E. International Organizations as Law Makers. New York: Oxford University Press, 2005.

Anaya, James. Indigenous People in International Law. New York: Oxford University Press, 1996.

Anaya, James y Robert A. Williams, Jr. "The Protection of Indigenous Peoples' Rights over Lands and Natural Resources under the Inter-American Human Rights System". Harvard Human Rights Journal 14 (2001). Disponible en http://www. law.harvard.edu/students/orgs/hrj/iss14/williams.shtml (última visita el 31 de octubre de 2009).

Anaya, James y Siegfried Wiessner. The UN Declaration on the Rights of Indigenous Peoples: Towards Re-empowerment, 3 de octubre de 2007. Disponible en http:// jurist.law.pitt.edu/forumy/2007/10/un-declaration-on-rights-of-indigenous.php (última visita el 12 de julio de 2010).

Andrade Geywitz, Carlos. "La Reforma Constitucional del Año 1989 al Inciso $2^{\circ}$ del Artículo $5^{\circ}$ de la Constitución: Sentido y Alcance de la Reforma". Revista Ius et Praxis, 9 (2003).

Ayres, Ian. Optional Law. The Structure of Legal Entitlements. Chicago: University of Chicago Press, 2005.

Ballesteros, Manuel. La Lei de Organización i Atribuciones de los Tribunales de Chile. Santiago: 1890.

Benadava, Santiago. Manual de Derecho Internacional Público. Santiago: Editorial Jurídica, $1^{\text {a }}$ ed., 1976.

_. Derecho Internacional Público. Santiago: Editorial Jurídica, 3ª ed., 1989.

- "Las Relaciones entre Derecho Internacional y Derecho Interno ante los Tribunales Chilenos". En Santiago Benadava, Nuevos Enfoques del Derecho Internacional. Santiago: Editorial Jurídica, 1992.

Bengoa, José. Historia del Pueblo Mapuche. Siglos XIX y XX. Santiago: Editorial LOM, $6^{\mathrm{a}}$ ed., 2000.

Bertelsen Repetto, Raúl. "Rango Jurídico de los Tratados Internacionales en el Derecho Chileno". Revista Chilena de Derecho 23 (1996).

Bleckman, Albert. "Self-Executing Treaty Provisions". En Rudolf Bernhardt, Encyplopedia of Public International Law 4. New York: North-Holland, 19922003.

Brownlie, Ian. Principles of Public International Law. New York: Oxford University Press, $6^{\text {a }}$ ed., 2003.

Bruna Contreras, Guillermo. "Los Tratados Internacionales en la Constitución de 1980: Jurisprudencia de la Década de 1981-1989”. Revista Ius et Praxis 9 (2003).

Calabresi, Guido y Douglas Melamed. "Property Rules, Liability Rules, and Inalienability: One View of the Cathedral". Harvard Law Review 85 (1972).

Carmona Santander, Carlos. "Comentarios a la Sentencia del Tribunal Constitucional sobre el Convenio $\mathrm{N}^{\circ} 169$ sobre Pueblos Indígenas". En Universidad de Chile, Los Tratados Internacionales en la Jurisprudencia Constitucional. Santiago: Universidad de Chile, 2001.

Cerda, Rodrigo A. "Situación Socioeconómica Reciente de los Mapuches en la Región de la Araucanía”. Estudios Públicos 113 (2009). 
Comisión de Verdad Histórica y Nuevo Trato. Informe de la Comisión de Verdad Histórica y Nuevo Trato. 2003. Disponible en http://biblioteca.serindigena.org/ index.php?option $=$ com_content\&task $=$ view\&id $=40 \&$ Itemid $=136$ (última visita el 11 de julio de 2010).

Correa, Martín (et al.). "La Reforma Agraria y las Tierras Mapuches. Chile 1962-1975". En Informe de la Comisión de Verdad Histórica y Nuevo Trato.

Correa G., Rodrigo. "Informe de Constitucionalidad Convenio 169 sobre Pueblos Indígenas y Tribales en Países Independientes, de la OIT”. Documento de Trabajo, Comisión de Verdad Histórica y Nuevo Trato, Subcomisión de Legislación, Santiago, 2002.

Cottier, Thomas y Maya Hertig. "The Prospects of $21^{\text {st }}$ Century Constitutionalism". Max Planck Yearbook of United Nations Law 7 (2003).

Dirección General de Presupuesto (DIPRES). Síntesis Ejecutiva. Programa Orígenes. Junio 2004. Disponible en http://www.dipres.cl/574/propertyvalue-15776.html (última visita 6 de marzo de 2010).

- Informe Final de Evaluación. Programa Orígenes. Ministerio de Planificación y Cooperación. Junio 2004. Disponible en http://www.dipres. cl/574/propertyvalue-15776.html (última visita 6 de marzo de 2010).

Duncker Biggs, Federico. Derecho Internacional Privado. Santiago: Editorial Jurídica, $2^{\mathrm{a}}$ ed., 1956.

Esty, Daniel C. "Good Governance at the Supranational Scale: Globalizing Administrative Law". Yale Law Journal 115 (2006).

Fernández González, Miguel Ángel. "Visión Prospectiva en Relación con la Regulación Constitucional de los Tratados Internacionales". Revista Ius et Praxis 9 (2003).

Franck, Thomas M. Fairness in International Law and Institutions. New York: Oxford University Press, 1995.

(ed.), Delegating State Powers: The Effect of Treaty Regimes on Democracy and Sovereignty. Ardsley: Transnational Publishers, 2000.

Gaete González, Eugenio Alberto. "Derecho Internacional y Derecho de los Estados. Incorporación de los Derechos Humanos". Revista Chilena de Derecho 23 (1996).

García Barzelatto, Ana María. "Control de Constitucionalidad de los Tratados Internacionales con Especial Referencia al Control Represivo". Revista de Derecho 69 (2007).

Gardbaum, Stephen. "Human Rights and International Constitutionalism". En Jeffrey L. Dunoff y Joel P. Trachtman, Ruling the World? Constitutionalim, International Law, and Global Governance. New York: Cambridge University Press, 2009.

Hartley, Trevor C. European Union Law in a Global Context. New York: Cambridge University Press, 2004.

Hayes, Edward T. "Changing Notion of Sovereignty and Federalism in the International Economic System: A Reassessment of WTO Regulation of Federal States and the Regional and Local Governments within their Territories". Northwestern Journal of International Law \& Business 25 (2004).

Held, David. "The Transformation of Political Community: Rethinking Democracy in the Context of Globalization”. En Ian Shapiro y Casiano Hacker-Cordón (eds.), Democracy's Edges. New York: Cambridge University Press, 1999.

Helfer, Laurence R. "Constitutional Analogies in the International Legal System". Loyola Los Angeles Law Review 37 (2003). 
Helfer, Laurence R. y Graeme B. Dinwoodie. "Designing Non-National Systems: The Case of the Uniform Domain Name Dispute Resolution Policy". William and Mary Law Review 43 (2001).

Infante Caffi, María Teresa. "Los Tratados en el Derecho Interno Chileno: El Efecto de la Reforma Constitucional de 1989 Visto por la Jurisprudencia”. Revista Chilena de Derecho 23 (1996).

Iwasawa, Yuji. "The Doctrine of Self-Executing Treaties in the United States: A Critical Analysis". Virginia Journal of International Law 26 (1986).

Kingsbury, Benedict. “'Indigenous Peoples' in International Law: A Constructivist Approach to the Asian Controversy". American Journal of International Law, 1998.

Kingsbury, Benedict, Nico Krisch y Richard B. Stewart. "The Emergence of Administrative Law". Law and Contemporary Problems 68 (2005).

Kumm, Mattias. "The Legitimacy of International Law: A Constitutionalist Framework". European Journal of International Law 15 (2004).

Ladeur, Karl-Heinz. "Globalization and the Conversion of Democracy to Polycentric Networks: Can Democracy Survive the End of the Nation State?'. En KarlHeinz Ladeur (ed.), Public Governance in the Age of Globalization. Ashgate, Burlington, 2004.

Libertad y Desarrollo. Temas Públicos N 939, de 16 de octubre de 2009.

Lowe, Vaugham. International Law. New York: Oxford University Press, 2007.

McCorquodale, Robert. "The Individual and the International Legal System”, 2003.

McGinnis, John O. y Mark L. Movsesian. "The World Trade Constitution”. Harvard Law Review, Vol. 114, 2000.

Medina Quiroga, Cecilia. "El Derecho Internacional de los Derechos Humanos". En Cecilia Medina y Jorge Mera (eds.), Seis Cuadernos de Análisis Jurídico: Sistema Jurídico y Derechos Humanos. El Derecho Nacional y las Obligaciones Internacionales de Chile en Materia de Derechos Humanos. 1996.

Meremiskaya, Elina. "El Convenio 169 de la OIT sobre Pueblos Indígenas y Tribales: Derecho Internacional y Experiencias Comparadas". Publicado en este mismo número (Estudios Públicos 120).

Meza-Lopehandía, Matías. El Reglamento sobre Consulta a Pueblos Indígenas Propuesto por el Gobierno de Chile, la Buena Fe y el Derecho Internacional de los Derechos Humanos. Disponible en http://www.observatorio.cl/wp-content/ uploads/2009/09/Reglamento-sobre-consulta inconsulto-+NYF-2a-ed.pdf (última visita el 5 de julio de 2010).

Mohor Abuauad, Salvador y Gustavo Fiamma Olivares. "La Jerarquía Normativa de los Tratados Internacionales". Revista de Derecho Público 55/56 (1994).

Montt Oyarzún, Santiago. "Aplicación de los Tratados Bilaterales de Protección de Inversiones por Tribunales Chilenos. Responsabilidad del Estado y Expropiaciones Regulatorias en un Mundo Crecientemente Globalizado". Revista Chilena de Derecho 32 (2005).

- State Liability in Investment Treaty Arbitration. Global Constitutional and Administrative Law in the BIT Generation. Oxford: Hart, 2009.

Nogueira Alcalá, Humberto. "Los Tratados Internacionales en el Ordenamiento Jurídico Chileno". Revista Chilena de Derecho 23 (1996).

Núñez Poblete, Manuel (dir.). Normativa Nacional e Internacional sobre Pueblos Indígenas. Santiago: Librotecnia, 2010. 
Observatorio Ciudadano. "Las Implicancias de la Ratificación del Convenio 169 de la OIT en Chile". Documento de Trabajo N 10, septiembre de 2009.

OIT (Organización Internacional del Trabajo). Convenio Número 169 sobre Pueblos Indigenas y Tribales: Un Manual. Francia, OIT, 2003.

- Los Derechos de los Pueblos Indígenas y Tribales en la Práctica: Una Guía sobre el Convenio Núm. 169 de la OIT. Disponible en http://www. ilo.org/wcmsp5/groups/public/---ed_norm/ normes/documents/publication/ wcms_113014.pdf (última visita 6 de noviembre de 2009).

- Guía para la Aplicación del Convenio Núm. 169 de la OIT. Disponible en http://www.oit.or.cr/mdtsanjo/indig/conten.htm (última visita 28 de octubre de 2009).

ONU. Consideración de Informes Presentados por Estados Partes bajo los Artículos 16 y 17 del Pacto. Observaciones Finales sobre la Federación Rusa, Trigésima Primera Sesión, N.U. Doc. E/C.12/1/Add.94, 12 de diciembre de 2003, p. 11. Disponible en http://www.unhchr.ch/tbs/doc.nsf/(Symbol)/E.C.12.1.Add.94. Sp?Opendocument.

ONU. Comité de Derechos Humanos. Comentario General No 23: Los Derechos de las Minorías. Quincuagésima sesión, 1994, ONU. Doc. CCPR/C/21Rev.1/Add.5, 4 de agosto de 1994. Disponible en http://www1.umn.edu/humanrts/gencomm/ hrcom23.htm (última visita, 23 de noviembre de 2009).

Orrego Vicuña, Francisco y Francisco Orrego Bauzá. "National Treaty Law and Practice: Chile". En Monroe Leigh et al. (eds)., National Treaty Law and Practice: Austria, Chile, Colombia, Japan, the Netherlands, and United States. American Society of International Law, 1999.

Partsch, Karl Joseph. "International Law and Municipal Law". En Rudolf Bernhardt, Encyplopedia of Public International Law, 2. New York: North-Holland, 19922003.

Paust, Jordan J. "Self-Executing Treaties". American Journal of International Law 82 (1988).

Peña Torres, Marisol. "Control de Constitucionalidad de los Tratados Internacionales: La Experiencia Chilena Un Año después de la Reforma de 2005". Revista de Derecho 69 (2007).

Pfeffer Urquiaga, Emilio. "Los Tratados Internacionales sobre Derechos Humanos y su Ubicación en el Orden Normativo Interno". Revista Ius et Praxis 9 (2003).

- Reformas Constitucionales 2005, Antecedentes, Debates, Informes. Santiago: Editorial Jurídica, 2005.

Pinto R., Jorge. "De la Inclusión a la Exclusión. La Formación del Estado, la Nación y el Pueblo Mapuche". En Comisión de Verdad Histórica y Nuevo Trato, Informe (ICVH NT-I), 2003.

Reisman, W. Michael. "Protecting Indigenous Rights in International Adjudication". American Journal of International Law 89 (1995).

Ribera Neumann, Teodoro. "El Derecho Internacional en la Jurisprudencia del Tribunal Constitucional Chileno". En Teodoro Ribera Neumann, Los Tratados Internacionales en la Jurisprudencia Constitucional. Santiago: Universidad de Chile, 2001.

-. "La Incorporación de los Tratados Internacionales al Orden Jurídico Interno". Revista de Derecho Público 69 (2007). 
Salinas Burgos, Hernán. "Los Tratados Internacionales ante la Reforma Constitucional". Revista de Derecho Público 69 (2007).

Shapiro, Martin. "Administrative Law Unbounded: Reflections on Government and Governance”. Indiana Journal of Global Legal Studies, Vol. 8, 2001.

Shaw, Malcolm N. International Law. New York: Cambridge University Press, $5^{\text {a }}$ ed., 2003.

Sierra, Lucas. "La Constitución y los Indígenas en Chile: Reconocimiento Individual y no Colectivo". Estudios Públicos 92 (2003).

Slaughter, Anne-Marie. A New World Order. Princeton: Princeton University Press, 2004.

Sloss, David. "The Domestication of International Human Rights". Yale Journal of International Law 24 (1999).

Stein, Eric. "International Integration and Democracy: No Love at First Sight". American Journal of International Law 95 (2001).

Steinhardt, Ralph G. International Civil Litigation: Cases and Materials on the Rise of International Law. Newark NJ: LexisNexis, 2002.

Tapia Valdés, Jorge. "Efectos de los Tratados sobre Derechos Humanos en la Jerarquía del Orden Jurídico y en la Distribución de Competencias: Alcances del Nuevo Inciso Segundo del Artículo $5^{\circ}$ de la CPR de 1980". Revista Ius et Praxis 9 (2003).

Tribe, Laurence H. Constitutional Choices. Cambridge: Harvard University Press, 1985.

Troncoso Repetto, Claudio y Tomás Vial Solar. "Sobre los Derechos Humanos Reconocidos en Tratados Internacionales en la Constitución”. Revista Chilena de Derecho 20 (1993).

Von Bogdandy, Armin. "Pluralism, Direct Effect, and the Ultimate Say: On the Relationship between International and Domestic Constitutional Law". International Journal of Constitutional Law 6, 2008.

Walker, Neil. "Beyond Boundary Disputes and Basic Grids: Mapping the Global Disorder of Normative Orders". International Journal of Constitutional Law, Vol. 6, 2008.

Wiessner, Siegfried. "Rights and Status of Indigenous Peoples: A Global Comparative and International Legal Analysis". Harvard Human Rights Journal 12 (1999).

Williamson. Oliver E. The Economic Institutions of Capitalism. New York: Free Press, 1985.

- The Mechanisms of Governance. N. York: Oxford University Press, 1996.

Xanthaki, Alexandra. Indigenous Rights and United Nations Standards. SelfDetermination, Culture and Land. New York: Cambridge University Press, 2007. 